Cochrane Database of Systematic Reviews

\title{
Thrombolysis for acute deep vein thrombosis (Review)
}

Watson L, Broderick C, Armon MP

Watson L, Broderick C, Armon MP.

Thrombolysis for acute deep vein thrombosis.

Cochrane Database of Systematic Reviews 2016, Issue 11. Art. No.: CD002783.

DOI: 10.1002/14651858.CD002783.pub4.

www.cochranelibrary.com 
TABLE OF CONTENTS

HEADER

ABSTRACT

PLAIN LANGUAGE SUMMARY

SUMMARY OF FINDINGS

BACKGROUND

OBJECTIVES

METHODS

RESULTS

Figure 1.

Figure 2.

Figure 3.

DISCUSSION

AUTHORS' CONCLUSIONS

ACKNOWLEDGEMENTS

REFERENCES

CHARACTERISTICS OF STUDIES

DATA AND ANALYSES

Analysis 1.1. Comparison 1 Any thrombolysis versus control, Outcome 1 Any improvement in venous patency (early).

Analysis 1.2. Comparison 1 Any thrombolysis versus control, Outcome 2 Complete clot lysis (early).

Analysis 1.3. Comparison 1 Any thrombolysis versus control, Outcome 3 Bleeding (early).

Analysis 1.4. Comparison 1 Any thrombolysis versus control, Outcome 4 Stroke/intracerebral haemorrhage (early). ...............

Analysis 1.5. Comparison 1 Any thrombolysis versus control, Outcome 5 Mortality (early).

Analysis 1.6. Comparison 1 Any thrombolysis versus control, Outcome 6 Pulmonary embolism (early).

Analysis 1.7. Comparison 1 Any thrombolysis versus control, Outcome 7 Post-thrombotic syndrome (intermediate). ..............

Analysis 1.8. Comparison 1 Any thrombolysis versus control, Outcome 8 Post-thrombotic syndrome (late).

Analysis 1.9. Comparison 1 Any thrombolysis versus control, Outcome 9 Leg ulceration (intermediate).

Analysis 1.10. Comparison 1 Any thrombolysis versus control, Outcome 10 Leg ulceration (late).

Analysis 1.11. Comparison 1 Any thrombolysis versus control, Outcome 11 Complete clot lysis (intermediate).

Analysis 1.12. Comparison 1 Any thrombolysis versus control, Outcome 12 Complete clot lysis (late)

Analysis 1.13. Comparison 1 Any thrombolysis versus control, Outcome 13 Mortality (intermediate).

Analysis 1.14. Comparison 1 Any thrombolysis versus control, Outcome 14 Mortality (late).

Analysis 1.15. Comparison 1 Any thrombolysis versus control, Outcome 15 Normal venous function (intermediate).

Analysis 1.16. Comparison 1 Any thrombolysis versus control, Outcome 16 Recurrent DVT (intermediate).

Analysis 2.1. Comparison 2 Systemic thrombolysis versus control, Outcome 1 Any improvement in venous patency (early). ....

Analysis 2.2. Comparison 2 Systemic thrombolysis versus control, Outcome 2 Complete clot lysis (early).

Analysis 2.3. Comparison 2 Systemic thrombolysis versus control, Outcome 3 Bleeding (early).

Analysis 2.4. Comparison 2 Systemic thrombolysis versus control, Outcome 4 Stroke/intracerebral haemorrhage (early). .......

Analysis 2.5. Comparison 2 Systemic thrombolysis versus control, Outcome 5 Mortality (early).

Analysis 2.6. Comparison 2 Systemic thrombolysis versus control, Outcome 6 Pulmonary embolism (early).

Analysis 2.7. Comparison 2 Systemic thrombolysis versus control, Outcome 7 Post-thrombotic syndrome (intermediate). .....

Analysis 2.8. Comparison 2 Systemic thrombolysis versus control, Outcome 8 Post-thrombotic syndrome (late). ...................

Analysis 2.9. Comparison 2 Systemic thrombolysis versus control, Outcome 9 Leg ulceration (intermediate).

Analysis 2.10. Comparison 2 Systemic thrombolysis versus control, Outcome 10 Leg ulceration (late).

Analysis 2.11. Comparison 2 Systemic thrombolysis versus control, Outcome 11 Complete clot lysis (intermediate).

Analysis 2.12. Comparison 2 Systemic thrombolysis versus control, Outcome 12 Complete clot lysis (late).

Analysis 2.13. Comparison 2 Systemic thrombolysis versus control, Outcome 13 Mortality (intermediate).

Analysis 2.14. Comparison 2 Systemic thrombolysis versus control, Outcome 14 Mortality (late).

Analysis 2.15. Comparison 2 Systemic thrombolysis versus control, Outcome 15 Normal venous function (intermediate). ......

Analysis 2.16. Comparison 2 Systemic thrombolysis versus control, Outcome 16 Recurrent DVT (late). 
Analysis 3.3. Comparison 3 Loco-regional thrombolysis versus control, Outcome 3 Stroke/intracerebral haemorrhage (early). .

Analysis 3.4. Comparison 3 Loco-regional thrombolysis versus control, Outcome 4 Mortality (early).

Analysis 3.5. Comparison 3 Loco-regional thrombolysis versus control, Outcome 5 Pulmonary embolism (early).

Analysis 3.6. Comparison 3 Loco-regional thrombolysis versus control, Outcome 6 Post-thrombotic syndrome (intermediate).

Analysis 3.7. Comparison 3 Loco-regional thrombolysis versus control, Outcome 7 Leg ulceration (intermediate). ..................

Analysis 3.8. Comparison 3 Loco-regional thrombolysis versus control, Outcome 8 Complete clot lysis (intermediate). ...........

Analysis 3.9. Comparison 3 Loco-regional thrombolysis versus control, Outcome 9 Mortality (intermediate).

Analysis 4.1. Comparison 4 Catheter-directed thrombolysis versus control, Outcome 1 Any improvement in venous patency (early).

Analysis 4.2. Comparison 4 Catheter-directed thrombolysis versus control, Outcome 2 Complete clot lysis (early).

Analysis 4.3. Comparison 4 Catheter-directed thrombolysis versus control, Outcome 3 Bleeding (early).

Analysis 4.4. Comparison 4 Catheter-directed thrombolysis versus control, Outcome 4 Stroke/intracerebral haemorrhage (early).

Analysis 4.5. Comparison 4 Catheter-directed thrombolysis versus control, Outcome 5 Mortality (early).

Analysis 4.6. Comparison 4 Catheter-directed thrombolysis versus control, Outcome 6 Pulmonary embolism (early).

Analysis 4.7. Comparison 4 Catheter-directed thrombolysis versus control, Outcome 7 Post-thrombotic syndrome (intermediate).

Analysis 4.8. Comparison 4 Catheter-directed thrombolysis versus control, Outcome 8 Post-thrombotic syndrome (late). ......

Analysis 4.9. Comparison 4 Catheter-directed thrombolysis versus control, Outcome 9 Leg ulceration (intermediate).

Analysis 4.10. Comparison 4 Catheter-directed thrombolysis versus control, Outcome 10 Complete clot lysis (intermediate). ..

Analysis 4.11. Comparison 4 Catheter-directed thrombolysis versus control, Outcome 11 Complete clot lysis (late).

Analysis 4.12. Comparison 4 Catheter-directed thrombolysis versus control, Outcome 12 Normal venous function (intermediate).

Analysis 4.13. Comparison 4 Catheter-directed thrombolysis versus control, Outcome 13 Recurrent VTE (intermediate). ........

Analysis 4.14. Comparison 4 Catheter-directed thrombolysis versus control, Outcome 14 Recurrent VTE (late).

Analysis 4.15. Comparison 4 Catheter-directed thrombolysis versus control, Outcome 15 Mortality (late). 
[Intervention Review]

\title{
Thrombolysis for acute deep vein thrombosis
}

\author{
Lorna Watson ${ }^{1}$, Cathryn Broderick ${ }^{2}$, Matthew P Armon ${ }^{3}$
}

${ }^{1}$ Cameron House, Leven, UK. 2 Usher Institute of Population Health Sciences and Informatics, University of Edinburgh, Edinburgh, UK.

${ }^{3}$ Department of General Surgery, Norfolk and Norwich University Hospital, Norwich, UK

Contact address: Lorna Watson, Cameron House, Cameron Bridge, Windygates, Leven, KY8 5RG, UK. Iwatson@nhs.net.

Editorial group: Cochrane Vascular Group.

Publication status and date: New search for studies and content updated (no change to conclusions), published in Issue 11, 2016.

Citation: Watson L, Broderick C, Armon MP. Thrombolysis for acute deep vein thrombosis. Cochrane Database of Systematic Reviews 2016, Issue 11. Art. No.: CD002783. DOI: 10.1002/14651858.CD002783.pub4.

Copyright $@ 2016$ The Cochrane Collaboration. Published by John Wiley \& Sons, Ltd.

\begin{abstract}
A B S T R A C T

\section{Background}

Standard treatment for deep vein thrombosis aims to reduce immediate complications. Use of thrombolysis or clot dissolving drugs could reduce the long-term complications of post-thrombotic syndrome (PTS) including pain, swelling, skin discolouration, or venous ulceration in the affected leg. This is the third update of a review first published in 2004.
\end{abstract}

\section{Objectives}

To assess the effects of thrombolytic therapy and anticoagulation compared to anticoagulation alone for the management of people with acute deep vein thrombosis (DVT) of the lower limb as determined by the effects on pulmonary embolism, recurrent venous thromboembolism, major bleeding, post-thrombotic complications, venous patency and venous function.

\section{Search methods}

For this update the Cochrane Vascular Information Specialist (CIS) searched the Specialised Register (February 2016). In addition the CIS searched the Cochrane Register of Studies (CENTRAL (2016, Issue 1)). Trial registries were searched for details of ongoing or unpublished studies.

\section{Selection criteria}

Randomised controlled trials (RCTs) examining thrombolysis and anticoagulation versus anticoagulation for acute DVT were considered.

\section{Data collection and analysis}

For this update (2016), LW and CB selected trials, extracted data independently, and sought advice from MPA where necessary. We assessed study quality with the Cochrane risk of bias tool. For dichotomous outcomes, we calculated the risk ratio (RR) and corresponding $95 \%$ confidence interval $(\mathrm{Cl})$. Data were pooled using a fixed-effect model unless significant heterogeneity was identified in which case a random-effects model was used. GRADE was used to assess the overall quality of the evidence supporting the outcomes assessed in this review.

\section{Main results}

Seventeen RCTs with 1103 participants were included. These studies differed in the both thrombolytic agent used and in the technique used to deliver it. Systemic, loco-regional and catheter-directed thrombolysis (CDT) were all included. Fourteen studies were rated as low risk of bias and three studies were rated as high risk of bias. We combined the results as any (all) thrombolysis compared to standard anticoagulation. Complete clot lysis occurred significantly more often in the treatment group at early follow-up ( $R R$ $4.91 ; 95 \% \mathrm{Cl} 1.66$ to $14.53, \mathrm{P}=0.004$ ) and at intermediate follow-up (RR 2.44; $95 \% \mathrm{Cl} 1.40$ to $4.27, \mathrm{P}=0.002$; moderate quality evidence). A similar effect was seen for any degree of improvement in venous patency. Up to five years after treatment significantly less PTS occurred in those receiving thrombolysis (RR $0.66,95 \% \mathrm{Cl} 0.53$ to $0.81 ; \mathrm{P}<0.0001$; moderate quality evidence). This reduction in PTS was still observed at late follow- 
up (beyond five years), in two studies (RR $0.58,95 \% \mathrm{Cl} 0.45$ to $0.77 ; \mathrm{P}<0.0001$; moderate quality evidence). Leg ulceration was reduced although the data were limited by small numbers ( $R R 0.87 ; 95 \% \mathrm{Cl} 0.16$ to $4.73, \mathrm{P}=0.87$ ). Those receiving thrombolysis had increased bleeding complications ( $R R 2.23 ; 95 \% \mathrm{Cl} 1.41$ to $3.52, \mathrm{P}=0.0006$; moderate quality evidence). Three strokes occurred in the treatment group, all in trials conducted pre-1990, and none in the control group. There was no significant effect on mortality detected at either early or intermediate follow-up. Data on the occurrence of pulmonary embolism (PE) and recurrent DVT were inconclusive. Systemic thrombolysis and CDT had similar levels of effectiveness. Studies of CDT included two trials in femoral and iliofemoral DVT, and results from these are consistent with those from trials of systemic thrombolysis in DVT at other levels of occlusion.

\section{Authors' conclusions}

Thrombolysis increases the patency of veins and reduces the incidence of PTS following proximal DVT by a third. Evidence suggests that systemic administration and CDT have similar effectiveness. Strict eligibility criteria appears to improve safety in recent studies and may be necessary to reduce the risk of bleeding complications. This may limit the applicability of this treatment. In those who are treated there is a small increased risk of bleeding. Using GRADE assessment, the evidence was judged to be of moderate quality due to many trials having low numbers of participants. However, the results across studies were consistent and we have reasonable confidence in these results.

\section{PLAIN LANGUAGE SUMMARY}

\section{Thrombolysis for treatment of acute deep vein thrombosis}

\section{Background}

Deep vein thrombosis (DVT) occurs when a blood clot forms in a leg vein. The clot can break up and move to the lungs, leading to a potentially serious blockage in blood flow (pulmonary embolism or PE). Because of the damage to the leg vein, post-thrombotic syndrome (PTS) may develop any time over the next couple of years. Symptoms include leg pain, swelling, skin pigmentation and leg ulcers, leading to loss of mobility. Anticoagulants are the standard treatment for DVT or a clot in a calf vein. These thin the blood to reduce further clots from forming and prevent PE; yet PTS can still develop. Thrombolysis breaks down the blood clot. For DVT, drugs such as streptokinase, urokinase and tissue plasminogen activator are infused into a vein in the arm or foot or, in some cases, directly at the site of the clot using a catheter and X-ray control. Bleeding complications, stroke or intracerebral haemorrhage are potential harmful events for both treatments.

\section{Study characteristics and key results}

The review results are based on 17 controlled trials that randomised a total of 1103 people with acute DVT (within 21 days of onset of symptoms) to receive thrombolysis or anticoagulant treatment. Trials were carried out principally in the USA, Scandinavia, Germany and the UK. All trials included men and women ranging in age from 18 to 75 years with a preponderance of older adults.

The present review (current until February 2016) showed that thrombolysis may have advantages over standard anticoagulation treatment. Thrombolysis effectively dissolved the clot so that complete clot breakdown occurred more often with thrombolysis than with standard anticoagulant therapy. Blood flow in the affected vein (venous patency) was also better maintained. Three trials (306 participants) continued for over six months and found that fewer people developed PTS when treated with thrombolysis, 45\% compared with $66 \%$ in the standard anticoagulation treatment group. Two trials (211 participants) which continued for over five years also showed that fewer people developed PTS when treated with thrombolysis.

Those receiving thrombolysis had more bleeding complications than with standard anticoagulation (10\% versus $8 \%$ ). Most bleeding episodes and deaths occurred in the older studies. Use of strict eligibility criteria appears to have improved the safety of this treatment, which is effective delivered directly to the clot by catheter or via bloodstream from another vein.

Qualitity of the evidence

Using GRADE assessment, the evidence was judged to be of moderate quality due to many trials having low numbers of participants. However, the results across studies were consistent and we have reasonable confidence in these results. 


\begin{tabular}{|c|c|c|c|c|c|c|}
\hline \multicolumn{7}{|c|}{ Treatment with any thrombolysis for acute deep vein thrombosis } \\
\hline \multicolumn{7}{|c|}{ Treatment with any thrombolysis for acute DVT } \\
\hline \multicolumn{7}{|c|}{$\begin{array}{l}\text { Patient or population: patients diagnosed with acute DVT } \\
\text { Setting: hospital } \\
\text { Intervention: any thrombolysis } \\
\text { Comparison: control anti-coagulation }\end{array}$} \\
\hline \multirow[t]{2}{*}{ Outcomes } & \multicolumn{2}{|c|}{$\begin{array}{l}\text { Anticipated absolute effects }{ }^{*}(95 \% \\
\mathrm{CI})\end{array}$} & \multirow{2}{*}{$\begin{array}{l}\text { Relative ef- } \\
\text { fect } \\
(95 \% \mathrm{CI})\end{array}$} & \multirow{2}{*}{$\begin{array}{l}\text { № of partici- } \\
\text { pants } \\
\text { (studies) }\end{array}$} & \multirow{2}{*}{$\begin{array}{l}\text { Quality of the } \\
\text { evidence } \\
\text { (GRADE) }\end{array}$} & \multirow[t]{2}{*}{ Comments } \\
\hline & $\begin{array}{l}\text { Risk with } \\
\text { control }\end{array}$ & $\begin{array}{l}\text { Risk with any } \\
\text { thrombolysis }\end{array}$ & & & & \\
\hline \multirow{2}{*}{$\begin{array}{l}\text { Complete clot lysis (intermedi- } \\
\text { ate, } 6 \text { months to under } 5 \text { years af- } \\
\text { ter treatment) }\end{array}$} & \multicolumn{2}{|c|}{ Study population } & \multirow{2}{*}{$\begin{array}{l}\text { RR } 2.44 \text { ( } 1.4 \text { to } \\
4.27)\end{array}$} & \multirow{2}{*}{$\begin{array}{l}630 \\
(7 \mathrm{RCTS})\end{array}$} & \multirow{2}{*}{$\begin{array}{l}\oplus \oplus \oplus \odot \\
\text { MODERATE } 1\end{array}$} & \multirow{2}{*}{$\begin{array}{l}78 \text { (of } 240 \text { ) patients treated with standard } \\
\text { anticoagulation had complete clot lysis } \\
\text { compared to } 198 \text { (of 390) in the thrombol- } \\
\text { ysis group }\end{array}$} \\
\hline & 325 per 1000 & $\begin{array}{l}793 \text { per } 1000(455 \\
\text { to } 1000)\end{array}$ & & & & \\
\hline \multirow{2}{*}{$\begin{array}{l}\text { Bleeding (early, up to } 1 \text { month af- } \\
\text { ter treatment) }\end{array}$} & \multicolumn{2}{|c|}{ Study population } & \multirow{2}{*}{$\begin{array}{l}\text { RR } 2.23 \\
\text { (1.41 to } 3.52 \text { ) }\end{array}$} & \multirow{2}{*}{$\begin{array}{l}1103 \\
(17 \mathrm{RCTs})\end{array}$} & \multirow{2}{*}{$\begin{array}{l}\oplus \oplus \oplus \odot \\
\text { MODERATE } 1\end{array}$} & \multirow{2}{*}{$\begin{array}{l}\text { Although } 17 \text { studies reported on bleeding, } \\
\text { these were small studies }\end{array}$} \\
\hline & 43 per 1000 & $\begin{array}{l}96 \text { per } 1000 \text { (61 to } \\
152)\end{array}$ & & & & \\
\hline \multirow{2}{*}{$\begin{array}{l}\text { Post-thrombotic syndrome (in- } \\
\text { termediate, } 6 \text { months to under } 5 \\
\text { years after treatment) }\end{array}$} & \multicolumn{2}{|c|}{ Study population } & \multirow{2}{*}{$\begin{array}{l}\text { RR } 0.66 \\
\text { (0.53 to } 0.81 \text { ) }\end{array}$} & \multirow{2}{*}{$\begin{array}{l}306 \\
\text { (3 RCTs) }\end{array}$} & \multirow{2}{*}{$\begin{array}{l}\oplus \oplus \oplus \odot \\
\text { MODERATE } 1\end{array}$} & \multirow{2}{*}{$\begin{array}{l}96 \text { (of 146) patients treated with standard } \\
\text { anticoagulation developed PTS compared } \\
\text { to } 72 \text { (of 160) treated with thrombolysis }\end{array}$} \\
\hline & 658 per 1000 & $\begin{array}{l}434 \text { per } 1000(348 \\
\text { to } 533)\end{array}$ & & & & \\
\hline \multirow{2}{*}{$\begin{array}{l}\text { Post-thrombotic syndrome (late, } \\
5 \text { year follow-up after treatment) }\end{array}$} & \multicolumn{2}{|c|}{ Study population } & \multirow{2}{*}{$\begin{array}{l}\text { RR } 0.58 \\
\text { ( } 0.45 \text { to } 0.77)\end{array}$} & \multirow{2}{*}{$\begin{array}{l}211 \\
(2 \text { RCTs) }\end{array}$} & \multirow{2}{*}{$\begin{array}{l}\oplus \oplus \oplus \ominus \\
\text { MODERATE } 1\end{array}$} & \multirow{2}{*}{$\begin{array}{l}72 \text { (of 107) patients treated with standard } \\
\text { anticoagulation developed PTS compared } \\
\text { to } 41 \text { (of 104) treated with thrombolysis }\end{array}$} \\
\hline & 673 per 1000 & $\begin{array}{l}390 \text { per } 1000(303 \\
\text { to } 518)\end{array}$ & & & & \\
\hline
\end{tabular}

${ }^{*}$ The risk in the intervention group (and its 95\% confidence interval) is based on the assumed risk in the comparison group and the relative effect of the intervention (and its $95 \% \mathrm{Cl}$ ).

CI: Confidence interval; DVT: deep vein thrombosis; PTS: post-thrombotic syndrome RCT: randomised controlled trial; RR: Risk ratio

\section{GRADE Working Group grades of evidence}

High quality: We are very confident that the true effect lies close to that of the estimate of the effect 
Moderate quality: We are moderately confident in the effect estimate: The true effect is likely to be close to the estimate of the effect, but there is a possibility that it is substantially different

Low quality: Our confidence in the effect estimate is limited: The true effect may be substantially different from the estimate of the effect

Very low quality: We have very little confidence in the effect estimate: The true effect is likely to be substantially different from the estimate of effect

1 Downgraded by one level as the number of participants in each study is smal

\section{Summary of findings 2 . Treatment with catheter directed thrombolysis for acute deep venous thrombosis}

Treatment with catheter directed thrombolysis for acute DVT

Patient or population: patients diagnosed with acute deep vein thrombosis

Setting: hospital

Intervention: catheter-directed thrombolysis

Comparison: control anti-coagulation

\begin{tabular}{|c|c|c|c|c|c|c|}
\hline \multirow[t]{2}{*}{ Outcomes } & \multicolumn{2}{|c|}{ Anticipated absolute effects ${ }^{\star}(95 \% \mathrm{Cl})$} & \multirow{2}{*}{$\begin{array}{l}\text { Relative ef- } \\
\text { fect } \\
(95 \% \mathrm{Cl})\end{array}$} & \multirow{2}{*}{$\begin{array}{l}\text { № of partici- } \\
\text { pants } \\
\text { (studies) }\end{array}$} & \multirow{2}{*}{$\begin{array}{l}\text { Quality of the } \\
\text { evidence } \\
\text { (GRADE) }\end{array}$} & \multirow[t]{2}{*}{ Comments } \\
\hline & Risk with control & $\begin{array}{l}\text { Risk with catheter direct- } \\
\text { ed thrombolysis }\end{array}$ & & & & \\
\hline \multirow{2}{*}{$\begin{array}{l}\text { Complete clot lysis (intermedi- } \\
\text { ate, } 6 \text { months to under } 5 \text { years } \\
\text { after treatment) }\end{array}$} & \multicolumn{2}{|l|}{ Study population } & \multirow{2}{*}{$\begin{array}{l}\text { RR } 2.52 \\
(0.52 \text { to } \\
12.17)\end{array}$} & \multirow{2}{*}{$\begin{array}{l}224 \\
(2 \mathrm{RCTS})\end{array}$} & \multirow{2}{*}{$\begin{array}{l}\oplus \oplus \oplus \ominus \\
\text { MODERATE } 1\end{array}$} & \\
\hline & \multicolumn{2}{|c|}{$\begin{array}{l}58 \text { (of 116) patients treated with standard anticoag- } \\
\text { ulation had complete clot lysis compared to } 81 \text { (of } \\
108 \text { ) in the CDT group }\end{array}$} & & & & \\
\hline \multirow{2}{*}{$\begin{array}{l}\text { Bleeding } \\
\text { (early, up to } 1 \text { month after } \\
\text { treatment) }\end{array}$} & \multicolumn{2}{|l|}{ Study population } & \multirow{2}{*}{$\begin{array}{l}\text { RR } 7.69 \\
(0.40 \text { to } \\
146.90)\end{array}$} & \multirow{2}{*}{$\begin{array}{l}224 \\
(2 \mathrm{RCTs})\end{array}$} & \multirow{2}{*}{$\begin{array}{l}\oplus \oplus \oplus \ominus \\
\text { MODERATE } 2\end{array}$} & \multirow{2}{*}{$\begin{array}{l}\text { None (of 116) patients in the } \\
\text { standard anticoagulation } \\
\text { group had bleeding compli- } \\
\text { cations compared to } 3 \text { (of } \\
\text { 108) in the CDT group. }\end{array}$} \\
\hline & \multicolumn{2}{|c|}{$\begin{array}{l}\text { Cannot define risk as no events reported in the stan- } \\
\text { dard anticoagulation group }\end{array}$} & & & & \\
\hline \multirow{2}{*}{$\begin{array}{l}\text { Post-thrombotic syndrome (in- } \\
\text { termediate, } 6 \text { months to under } \\
5 \text { years after treatment) }\end{array}$} & \multicolumn{2}{|l|}{ Study population } & \multirow{2}{*}{$\begin{array}{l}\text { RR } 0.74 \\
\text { (0.55 to } 1.00)\end{array}$} & \multirow{2}{*}{$\begin{array}{l}189 \\
(1 \mathrm{RCT})\end{array}$} & \multirow{2}{*}{$\begin{array}{l}\oplus \oplus \oplus \ominus \\
\text { MODERATE } 3\end{array}$} & \multirow{2}{*}{$\begin{array}{l}55 \text { (of 99) patients in the } \\
\text { standard anticoagulation } \\
\text { group developed PTS com- } \\
\text { pared to } 37 \text { (of 90) in the } \\
\text { CDT group. }\end{array}$} \\
\hline & 556 per 1000 & 411 per 1000 (306 to 556$)$ & & & & \\
\hline \multirow{2}{*}{$\begin{array}{l}\text { Post-thrombotic syndrome } \\
\text { (late, } 5 \text { year follow-up after } \\
\text { treatment) }\end{array}$} & \multicolumn{2}{|l|}{ Study population } & \multirow{2}{*}{$\begin{array}{l}\text { RR } 0.60 \\
(0.45 \text { to } 0.79)\end{array}$} & \multirow{2}{*}{$\begin{array}{l}176 \\
(1 \mathrm{RCT})\end{array}$} & \multirow{2}{*}{$\begin{array}{l}\oplus \oplus \oplus \ominus \\
\text { MODERATE }\end{array}$} & \multirow{2}{*}{$\begin{array}{l}63 \text { (of } 89 \text { ) patients in the } \\
\text { standard anticoagulation } \\
\text { group developed PTS com- }\end{array}$} \\
\hline & 708 per 1000 & 425 per 1000 (319 to 559$)$ & & & & \\
\hline
\end{tabular}
treatment) 
${ }^{\star}$ The risk in the intervention group (and its $95 \%$ confidence interval) is based on the assumed risk in the comparison group and the relative effect of the intervention (and its $95 \% \mathrm{Cl}$ ).

CDT: catheter-directed thrombolysis; Cl: Confidence interval; DVT: deep vein thrombosis; PTS: post-thrombotic syndrome; RCT: randomised controlled trial RR: Risk ratio

\section{GRADE Working Group grades of evidence}

High quality: We are very confident that the true effect lies close to that of the estimate of the effect

Moderate quality: We are moderately confident in the effect estimate: The true effect is likely to be close to the estimate of the effect, but there is a possibility that it is substantially different

Low quality: Our confidence in the effect estimate is limited: The true effect may be substantially different from the estimate of the effect

Very low quality: We have very little confidence in the effect estimate: The true effect is likely to be substantially different from the estimate of effect

1 Downgraded by one level as confidence intervals are wide around the estimate of the effect

2 Downgraded by one level as confidence intervals wide around the estimate of effect. Studies did not report any bleeding events in standard anticoagulation group

3 Results are from one small study with a small number of events. Downgraded by one level 


\section{B A C K G R O U N D}

\section{Description of the condition}

Deep vein thrombosis (DVT) is a major health problem with between $2.5 \%$ to $5 \%$ of the population affected at some time in their lives (Browse 1999; White 2006). Its main complications are pulmonary embolism (PE) in the short term and post-thrombotic syndrome (PTS) in the long term. Standard treatment is with anticoagulation (thinning the blood to reduce formation of further clots) and is aimed mainly at the prevention of PE and recurrent DVT (Kearon 2016; NICE 2012). Despite treatment, over 50\% of patients may suffer post-thrombotic symptoms in the long term, manifested by some degree of pain, swelling, skin pigmentation or venous ulceration of the affected leg (Kahn 2006; Schulman 2006). This usually becomes apparent in the first two years after the thrombotic event (Brandjes 1997; Kahn 2004; Kahn 2008). Most studies report eventual venous ulceration in at least $6 \%$ of DVT patients despite treatment with compression bandaging (Johnson 1995; Schulman 2006). The prevalence of venous ulcers in the general population is around 1 in 1000 , and between $40 \%$ to $50 \%$ of patients with venous ulcers have evidence of post-thrombotic damage (Browse 1999; Kahn 2004). Complications including venous ulcers may result in significant disability and may be difficult to manage in both the community and secondary care. Because complications develop after hospital admission, there is a low level of awareness of these complications amongst the clinicians who dealt with the acute admission.

\section{Description of the intervention}

Thrombolytic drugs act to dissolve blood clots by activating plasminogen. This forms an enzyme called plasmin that breaks links between the fibrin molecules, which make up blood clots. The drugs can be administered systemically through a peripheral vein, loco-regionally via a vein close to the clot or directly via a catheter to the occluding thrombus. The latter method more directly targets plasminogen within the clot and is less affected by potential inhibitors in the circulation.

\section{How the intervention might work}

Dissolving the thrombus in the acute phase may reduce the risk of more permanent damage to the structure and function of the vein, in particular venous valvular function, thus lowering the risk of post-thrombotic complications in the long term.

\section{Why it is important to do this review}

This systematic review draws together previous comparative trials of thrombolysis and anticoagulation to reassess the advantages and disadvantages of thrombolytic therapy in the context of acute lower limb DVT and to identify areas for future research. This systematic review is an update of a previously published Cochrane review (Armon 2000; Watson 2004 ; Watson 2010; Watson 2014).

\section{O B JECTIVES}

To assess the effects of thrombolytic therapy and anticoagulation compared to anticoagulation alone for the management of people with acute DVT of the lower limb as determined by the effects on clot lysis, bleeding and post thrombotic syndrome and other relevant outcomes.

\section{METHODS}

\section{Criteria for considering studies for this review}

\section{Types of studies}

All randomised trials of thrombolysis and anticoagulation versus anticoagulation for acute lower limb DVT were considered. Any method of randomisation was eligible, and differences in quality were taken into account in the analysis. Trials that were not analysed on an intention-to-treat basis were included provided all randomised participants were accounted for.

\section{Types of participants}

Trials of participants with acute DVT, defined as onset of symptoms within seven days and confirmed by objective testing with, for example, venography or duplex ultrasonography, were considered. Trials including participants with chronic or recurrent venous thrombosis were excluded, as were those with participants commencing treatment after a maximum of 21 days from the onset of symptoms. Trials including participants with arm vein thrombosis were included in the update when the majority of cases affected the lower limb.

\section{Types of interventions}

Trials with the use of any thrombolytic agent were included, the principal ones being streptokinase, urokinase and tissue plasminogen activator (tPA); other agents were included if used for the treatment of acute DVT. All routes of drug lysis administration were considered as were different dosing regimens of lytic agents. This included systemic and catheter-directed thrombolysis (CDT) methods.

\section{Types of outcome measures}

Outcomes were classified into early (up to one month); intermediate (after six months to five years) or late (more than five years) from time of intervention (see Included studies). When data were reported between one and six months, we planned to discuss and reassess the definition of our time points as required.

\section{Primary outcomes}

The following primary outcomes were included:

- Any improvement in venous patency (assessed by objective measures such as venography, where pre- and post-comparative data on the degree of restoration of the lumen were available);

- Complete clot lysis (defined as achievement of full patency of the affected vein, or complete dissolution of the clot, by objective measures);

- Bleeding complications excluding stroke or intracerebral haemorrhage (defined as bleeding causing treatment to be stopped, requiring transfusion or surgery, or causing chronic or fatal sequelae);

- Stroke and in particular haemorrhagic stroke (preferably documented by objective means such as a computerised tomography scan or autopsy);

- PTS;

- Venous ulceration rates; and

- Mortality. 


\section{Secondary outcomes}

Secondary outcomes included:

- Recurrent DVT;

- PE;

- Venous function (assessed by duplex ultrasound or other objective means such as foot volumetry or ambulatory venous pressure measurements);

- Quality of life (QoL); and

- Cost comparisons.

\section{Search methods for identification of studies}

\section{Electronic searches}

For this update the Cochrane Vascular Information Specialist (CIS) searched the following databases for relevant trials (February 2016):

- The Cochrane Vascular Specialised Register; and

- The Cochrane Central Register of Controlled Trials (CENTRAL (2016, Issue 1)) via The Cochrane Register of Studies Online.

There were no restrictions on language. See Appendix 1 for details of the search strategy used to search CENTRAL.

The Specialised Register is maintained by the CIS and is constructed from weekly electronic searches of MEDLINE, EMBASE, CINAHL, AMED, and through handsearching relevant journals. The full list of the databases, journals and conference proceedings which have been searched, as well as the search strategies used are described in the Specialised Register section of the Cochrane Vascular module in the Cochrane Library (www.cochranelibrary.com).

The CIS searched the following trial registries for details of ongoing and unpublished studies using the terms 'thrombosis AND thrombolysis' (February 2016):

- ClinicalTrials.gov (www.clinicaltrials.gov);

- World Health Organization International Clinical Trials Registry Platform (www.who.int/trialsearch); and

- ISRCTN Register (www.isrctn.com/).

\section{Searching other resources}

The reference lists of articles retrieved by electronic searches were searched for additional citations.

\section{Data collection and analysis}

Data were collected from the original papers and authors were contacted for clarification where necessary.

\section{Selection of studies}

LW and CB identified possible trials.

\section{Data extraction and management}

Data were collected using pro formas designed by Cochrane Vascular. For this 2016 update, LW and CB independently completed data extraction. Authors of ongoing trials were contacted to check for available data but no response was received.

\section{Assessment of risk of bias in included studies}

Study quality was independently assessed by two review authors (LW and $\mathrm{CB}$, or MPA and $\mathrm{CB}$ ) using forms designed according to Cochrane and Cochrane Vascular guidelines and the Cochrane risk of bias tool (Higgins 2011). Any disagreements were resolved by discussion.

\section{Measures of treatment effect}

Statistical analyses were performed according to the statistical guidelines for review authors provided by Cochrane Vascular. If appropriate, for each dichotomous outcome we calculated a summary statistic using the risk ratio (RR) and corresponding 95\% confidence interval $(\mathrm{Cl})$.

\section{Unit of analysis issues}

Individual participants were the unit of analysis. If appropriate, the control groups in the multiple arm trials were divided up to avoid double counting in the meta-analysis.

\section{Dealing with missing data}

Intention-to-treat analysis was conducted where possible. Any missing statistics were recalculated from original data where available. Authors were contacted to request data where it was not possible to identify specific event numbers from the data reported.

\section{Assessment of heterogeneity}

Heterogeneity was assessed clinically from descriptions of studies, visually from forest plots and statistically using the $\mathrm{Chi}^{2}$ test. If $\mathrm{P}$ $<0.05$ a random-effects model was used, otherwise a fixed-effect model was reported. We also considered heterogeneity by clinical judgements of differences in participant populations, interventions and outcome assessments.

\section{Assessment of reporting biases}

Reporting bias was assessed through a review of the studies identified and funnel plots were considered if relevant.

\section{Data synthesis}

We pooled studies for meta-analysis when the interventions, patient groups, outcome measures and timing of outcome assessment were sufficiently similar (determined by consensus). The pooled RR and corresponding $95 \% \mathrm{Cl}$ were calculated for dichotomous outcomes. A fixed-effect model was used unless statistical heterogeneity was identified (as described above), in which case a random-effects model was used.

\section{Subgroup analysis and investigation of heterogeneity}

Trials were analysed together and in subgroups according to route of administration. Other sources of heterogeneity such as participant selection, type of DVT, drug or dose were commented on where relevant.

\section{Sensitivity analysis}

Sensitivity analysis included the exclusion of studies deemed to be at high risk of bias from pooled analyses to see whether this would influence the results. 


\section{Summary of findings}

We created 'Summary of findings' tables using the GRADEpro software. This summarised the evidence comparing thrombolysis to standard anticoagulation for study populations consisting of patients with acute DVT (Summary of findings for the main comparison); and comparing CDT versus standard anticoagulation for DVT (Summary of findings 2). The most important and clinically relevant outcomes (both desirable and undesirable) that were thought to be essential for decision-making were the outcomes complete clot lysis, bleeding and post-thrombotic syndrome. Assumed control intervention risks were calculated by the mean number of events in the control groups of the selected studies for each outcome. The system developed by the Grades of Recommendation, Assessment, Development and Evaluation Working Group (GRADE working group) was used for grading the quality of evidence as high, moderate, low and very low, based on within-study risk of bias, inconsistency, directness of evidence, imprecision, and publication bias (Atkins 2004).

\section{RE S U L T S}

\section{Description of studies}

\section{Results of the search}

No new included studies were identified for this 2016 update (See Figure 1). Nine additional publications from the Cavent study (Enden 2011) were identified, one of which reported five year follow-up data (Haig 2016). Seven new studies were excluded (Bashir 2014; Cakir 2014; Engelberger 2015; Patra 2014; Santiago 2014; Sui 2013; Zhang 2014), and two new ongoing studies were identified (IRCT201108035625N3; NCT00970619). 
Figure 1. Study flow diagram.

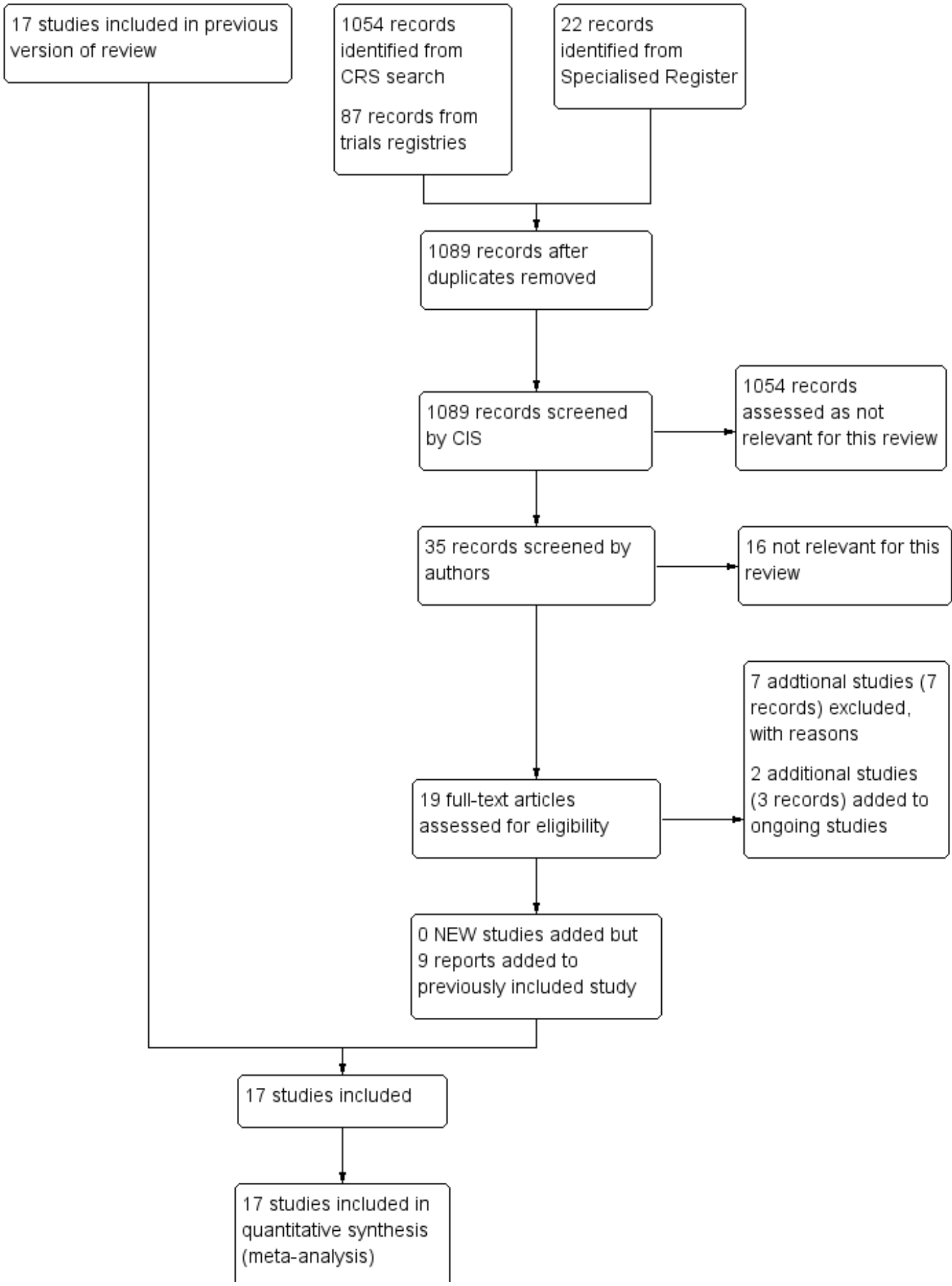


Figure 1. (Continued)

$$
\text { (meta-analysis) }
$$

\section{Included studies}

In total 17 trials were included, with 1103 participants (Arneson 1978; Common 1976; Elliot 1979; Elsharawy 2002; Enden 2011; Goldhaber 1990; Goldhaber 1996; Kakkar 1969; Kiil 1981; Marder 1977; Schulman 1986; Schweizer 1998; Schweizer 2000; Tsapogas 1973; Turpie 1990; Ugurlu 2002; Verhaeghe 1989). Studies were carried out from 1969 to 2009. A cut-off of 21 days from onset of symptoms was used, therefore a small number of studies excluded on this basis from the original review were included.

\section{Participants}

Trials were carried out principally in the USA, Scandinavia, Germany and the UK. All trials included men and women and the age range was 18 to 75 years with a preponderance of older adults. The participants had diverse underlying causes for developing DVT, and varying degrees of level and extent of occlusion. The trial by Elsharawy 2002 was conducted in DVT affecting femoral and iliofemoral veins and Enden 2011 included pelvic, femoral and iliofemoral veins, whereas other trials included thrombosis affecting different combinations of levels, including popliteal. The only study to include calf vein thrombosis only was Schulman 1986. See Table 1, 'Level of affected leg veins in included studies'.

\section{Inclusion criteria}

Inclusion criteria have become more restrictive over time. In the earliest study by Kakkar 1969, there were only four contraindications: surgery within three days, an unhealed wound, peptic ulcer and hypertension. By the time of Schweizer 2000, a more comprehensive list of contra-indications had been developed including: surgery or head trauma within the previous three months, malignancy, renal and hepatic dysfunction, and bleeding dysfunction, which in later studies reduces the proportion of eligible participants.

\section{Interventions}

Interventions included systemic, loco-regional and CDT. Systemic and loco-regional techniques differ only in the veins used to deliver an infusion: the arm or foot respectively. CDT is a more invasive procedure in which a catheter is inserted into the popliteal vein behind the knee using X-ray control. The thrombolytic agent is infused through the catheter into the blood clot itself and the position of the catheter is altered according to the progress made in lysing the blood clot. The majority of trials assessed systemic thrombolysis, with streptokinase the most common agent used. The dose used varied: Schulman 1986 used a lowdose regime of systemic streptokinase, Tsapogas 1973 used locoregional streptokinase and Elsharawy 2002 used catheter-directed streptokinase with frequent radiological assessment, a technique used again in Enden 2011.

Goldhaber 1990, Turpie 1990 and Verhaeghe 1989 used systemic tPA. While doses of tPA varied, there was no obvious cut-off for high or low doses. Goldhaber 1996 randomised two regimes of tPA, with and without heparin, compared to heparin alone. The two treatment arms were combined for the purposes of this review.
Schweizer 1998 had two treatment arms, loco-regional tPA and urokinase; and Schweizer 2000 had four treatment arms: systemic streptokinase, systemic urokinase, loco-regional urokinase and loco-regional tPA. Kiil 1981 used low-dose systemic urokinase.

\section{Co-treatments}

Monitoring regimes for heparinisation varied, and length of anticoagulation after the initial phase may be limited to a few months or continued for over a year. In some trials, especially the more recent ones, the use of compression bandages and elevation were reported; and for longer follow-up, some participants were required to use compression stockings with rigorous ascertainment of compliance with the continued treatment.

\section{Size}

Nine studies had less than 50 participants (Arneson 1978; Elsharawy 2002; Goldhaber 1996; Kakkar 1969; Kiil 1981; Marder 1977; Schulman 1986; Tsapogas 1973; Verhaeghe 1989), and two studies had more than 100 participants (Enden 2011; Schweizer 2000). Most studies therefore lacked power to detect statistically significant effects. A power calculation was described in three studies (Elsharawy 2002; Enden 2011; Schweizer 2000). Schweizer 2000 was the largest trial with 250 participants.

\section{Outcomes}

One trial (Verhaeghe 1989), reported results for randomised participants together with non-randomised participants. Some studies reported outcomes using scales which could not be combined (Marder 1977). Removal of the clot was reported using various categorisations. Both complete clot dissolution or lysis, indicating that the venous patency was $100 \%$ restored, and any degree of venographic improvement in patency were reported in this review in order to capture as much information as possible. Tsapogas 1973 reported partial or complete clearance (75\% to $100 \%)$, a measure not used in any other study, and others reported partial clearance (50\% to $100 \%)$. One study reported on Qol and cost comparisons (Enden 2011).

\section{Length of follow-up}

All trials assessed outcomes in the period immediately after treatment. This was usually at one week, although the range was 36 hours to one month. We collectively grouped these as early outcomes. Intermediate outcomes have been classified as those determined after six months and under 5 years. No data were reported between this early and intermediate phase (i.e. after one month and before six months). Late outcomes were those reported 5 years or more after the intervention. PTS was assessed between one and six years. The longest follow-up (six years) was in the Arneson 1978 study. For this update (2016), late data (five year follow-up) from Enden 2011 has been included.

\section{Excluded studies}

Seven additional trials were excluded for this 2016 update (Bashir 2014; Cakir 2014; Engelberger 2015; Patra 2014; Santiago 2014; Sui 2013; Zhang 2014). Reasons for exclusion included not randomised 
(Bashir 2014; Santiago 2014), did not compare thrombolysis with anticoagulant (Cakir 2014; Engelberger 2015; Sui 2013; Zhang 2014), and onset of symptoms beyond 21 days (Patra 2014). Sixteen trials were previously excluded because they did not meet the inclusion criteria. Four trials (Browse 1968; Johansson 1979; Robertson 1967; Schweizer 1996) did not satisfy the criteria for randomisation. In other cases, studies did not include a comparison of thrombolysis versus anticoagulation, or DVT was not confirmed objectively (Bieger 1976; Marini 1991; Markevicius 2004; Pinto 1997; Silistreli 2004; Tibbutt 1974; Tibbutt 1977; Zimmermann 1986). In three cases insufficient information was obtained despite attempts to contact the authors (Ansell 1990; Persson 1977; Sas 1985). TORPEDO 2012 was excluded as only 33 out 90 participants received thrombolysis. See the Characteristics of excluded studies table for further information.

\section{Ongoing Studies}

Two new ongoing studies were identified (IRCT201108035625N3; NCT00970619). See Characteristics of ongoing studies for further details. We contacted the study investigators of these to ask if any data were available but we did not receive a response.

\section{Risk of bias in included studies}

The quality of reporting of the majority of trials was high, see Figure 2 and Figure 3. See the Characteristics of included studies table for detailed information. Minor protocol violations were reported in several studies, and losses to follow-up were more common in the later phases.

Figure 2. Risk of bias graph: review authors' judgements about each risk of bias item presented as percentages across all included studies.

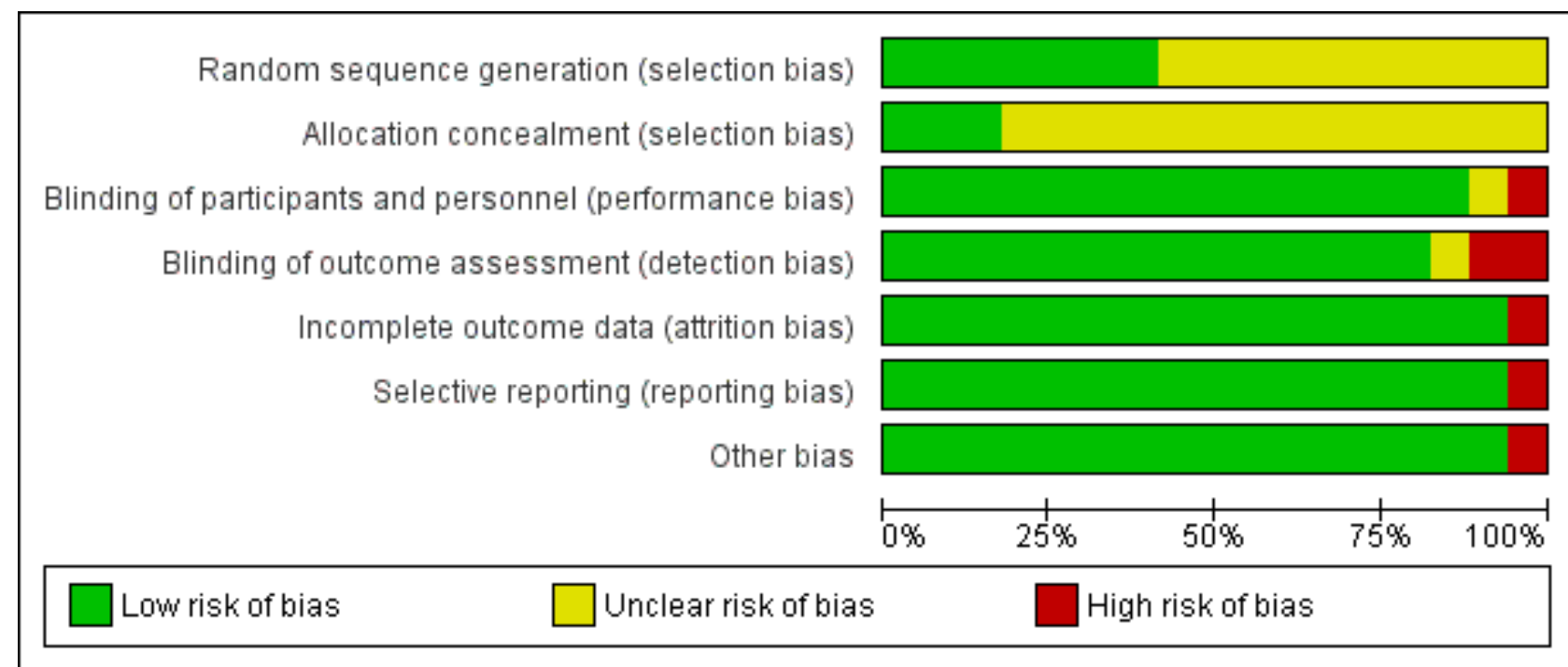


Figure 3. Risk of bias summary: review authors' judgements about each risk of bias item for each included study.

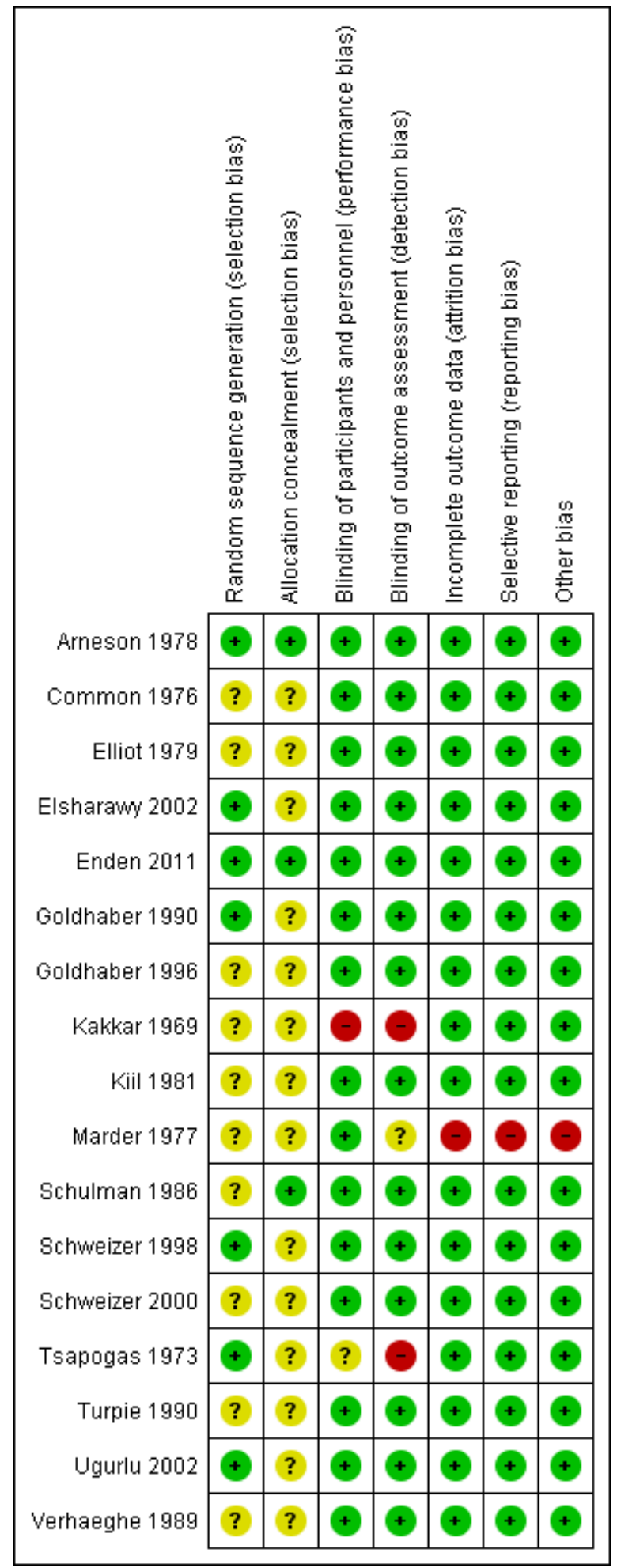

\section{Allocation}

Many studies reported random allocation from a random numbers table or computer generated sequence (Arneson 1978; Elsharawy 2002; Enden 2011; Goldhaber 1990; Schulman 1986; Schweizer 1998; Tsapogas 1973; Ugurlu 2002; Verhaeghe 1989), although sometimes this detail was lacking (Common 1976; Elliot 1979;
Goldhaber 1996; Kiil 1981; Marder 1977; Schweizer 2000; Turpie 1990; Verhaeghe 1989). Many older studies did not give details on allocation concealment, and this remained a possible risk of bias (Common 1976; Elliot 1979; Elsharawy 2002; Kiil 1981; Marder 1977; Schweizer 1998; Schweizer 2000; Turpie 1990; Ugurlu 2002; Verhaeghe 1989). Studies with good allocation concealment 
also found significant effects. In some cases insufficient detail was reported on whether envelopes were sequentially numbered, sealed or opaque (Common 1976; Elliot 1979; Goldhaber 1996; Schulman 1986; Tsapogas 1973).

\section{Blinding}

With the exception of Tsapogas (Tsapogas 1973), all studies used blinding for the assessment of venograms. Turpie 1990 and Verhaeghe 1989 used identical placebo infusions and therefore were double blind. Where participants were not blinded to the treatment group (Arneson 1978; Common 1976; Elliot 1979; Elsharawy 2002; Enden 2011; Goldhaber 1990; Goldhaber 1996; Kakkar 1969; Marder 1977; Schweizer 1998; Schweizer 2000; Tsapogas 1973; Ugurlu 2002), an assessment was made that this introduced a low risk of bias where the assessor was blinded and using objective measures, which was the case in most studies (Arneson 1978; Common 1976; Elliot 1979; Elsharawy 2002; Enden 2011; Goldhaber 1990; Goldhaber 1996; Schulman 1986; Schweizer 1998; Schweizer 2000; Turpie 1990; Ugurlu 2002; Verhaeghe 1989). Blinding participants would be more difficult with more interventional approaches. However, this lack of blinding of participants may have introduced bias in the longer term as participants in receipt of thrombolysis may be more likely to have impressed upon them, or to heed advice given on, the importance of complying with co-treatments such as compression stockings. For example, compliance was higher in the treatment group in Enden 2011. In Kakkar 1969 neither the participants nor outcome assessors were blinded, and this study was therefore judged to have a high risk of bias.

\section{Incomplete outcome data}

Most studies did not demonstrate any major differences in followup between the treatment and control groups for the main outcomes, in the early or intermediate follow-up periods. Marder 1977 was assessed as having high risk of bias for this category as it was not possible to separate the data from the three patients who were added non-randomly after randomisation took place.

\section{Selective reporting}

In some cases subgroups were reported that did not include all trial participants, for example PTS in those with complete clot lysis, but these were not included in the review. As results including non-randomised participants were reported in Marder 1977, this was judged as at high risk of bias. Duplicate reports of studies were identified in the selection process and multiple sources were searched, with no language restriction. A funnel plot was not used as there were less than 10 studies reporting on the most relevant outcomes measuring effect.

\section{Other potential sources of bias}

There were no other specific concerns about bias except for Marder 1977 who added three non-randomised participants to the study post-randomisation.

\section{Effects of interventions}

See: Summary of findings for the main comparison Treatment with any thrombolysis for acute deep vein thrombosis; Summary of findings 2 Treatment with catheter directed thrombolysis for acute deep venous thrombosis

\section{Comparison 1. Any thrombolysis versus control}

Seventeen studies were included for this comparison (Arneson 1978; Common 1976; Elliot 1979; Elsharawy 2002; Enden 2011; Goldhaber 1990; Goldhaber 1996; Kakkar 1969; Kiil 1981; Marder 1977; Schulman 1986; Schweizer 1998; Schweizer 2000; Tsapogas 1973; Turpie 1990; Ugurlu 2002; Verhaeghe 1989).

\section{Outcome 1: any improvement in venous patency (early)}

Nine trials reported on improvements in venous patency defined by a change in occlusion of the affected segment after treatment (Arneson 1978; Common 1976; Elsharawy 2002; Goldhaber 1990; Goldhaber 1996; Kakkar 1969; Kiil 1981; Turpie 1990; Ugurlu 2002). With all studies except Kiil 1981, improvement was more marked in the treatment group. Out of a total of 610 participants, improvement was significantly more likely in those receiving thrombolysis (RR 2.48; $95 \% \mathrm{Cl} 1.35$ to $4.57, \mathrm{P}=0.004$; Analysis 1.1). Statistical heterogeneity was noted in the results and a randomeffects model was used. The study by Marder 1977, which showed a difference in mean change from venograms, could not be included due to the reporting format used. A greater improvement was noted but for randomised participants this was not reported to be significantly different. Similarly the Verhaeghe 1989 data could not be included in the meta-analysis.

\section{Outcome 2: complete clot lysis (early)}

Eight trials with 592 participants reported on the occurrence of complete clot lysis (Common 1976; Elliot 1979; Elsharawy 2002; Goldhaber 1990; Kakkar 1969; Schulman 1986; Schweizer 2000; Ugurlu 2002). In all trials this was more likely in the treatment group, although the extent of the effect varied and the results were statistically heterogeneous. A random-effects model demonstrated a significant improvement (RR 4.91; $95 \% \mathrm{Cl} 1.66$ to $14.53, \mathrm{P}=0.004$; Analysis 1.2).

\section{Outcome 3: bleeding (early)}

This category excluded cerebral bleeding and minor bleeds, for example oozing from venepuncture sites and superficial haematomas. All 17 trials reported on the occurrence of bleeding episodes (Arneson 1978; Common 1976; Elliot 1979; Elsharawy 2002; Enden 2011; Goldhaber 1990; Goldhaber 1996; Kakkar 1969; Kiil 1981; Marder 1977; Schulman 1986; Schweizer 1998; Schweizer 2000; Tsapogas 1973; Turpie 1990; Ugurlu 2002; Verhaeghe 1989). While none of the studies individually showed a statistically significant increase in bleeding, participants receiving thrombolysis were significantly more likely than control participants to experience a bleeding complication. Nine per cent $(62 / 662)$ of patients in the thrombolysis group experienced a bleeding complication compared to $4 \%(19 / 441)$ of patients in the standard anticoagulation group (RR 2.23; $95 \% \mathrm{Cl} 1.41$ to $3.52, \mathrm{P}=$ 0.0006; moderate quality evidence; Analysis 1.3 ), with a number needed to treat for an additional harmful outcome (NNTH) of 17.

\section{Outcome 4: stroke or intracerebral haemorrhage (early)}

Three trials reported the occurrence of stroke or intracerebral haemorrhage (Common 1976; Goldhaber 1990; Marder 1977). All trials described bleeding complications, therefore the absence of mention of any serious neurological complications or cerebral bleeds was taken to indicate that none were detected. Out of a total of 1103 participants three events occurred in the treatment group (a rate of $0.3 \%$ ) and none in the control group. The pooled RR was 
$1.92(95 \% \mathrm{Cl} 0.34$ to 10.86$)$ with wide uncertainty regarding the true effect (Analysis 1.4).

\section{Outcome 5: mortality (early)}

Nine trials reported deaths occurring up to one month after treatment (Arneson 1978; Common 1976; Elliot 1979; Elsharawy 2002; Kakkar 1969; Kiil 1981; Marder 1977; Schulman 1986; Schweizer 2000); two trials reported that no deaths occurred in this period (Elsharawy 2002; Schweizer 2000). A total of five events occurred in the treatment group and seven in the control group out of a total 529 participants. The pooled RR was $0.76(95 \% \mathrm{Cl} 0.31$ to 1.89; Analysis 1.5); however the wide $\mathrm{Cl}$ indicated a large degree of uncertainty around the true effect and there were relatively few events.

\section{Outcome 6: pulmonary embolus (PE) (early)}

Six trials reported the occurrence of a PE in the early phase (Arneson 1978; Elliot 1979; Elsharawy 2002; Kakkar 1969; Schulman 1986; Schweizer 2000). One study noted the absence of any PE (Schulman 1986). The diagnostic criteria used were variable. With the exception of participants who died from PE (one in the treatment group, two in the control group), transient clinical symptoms often occurred but with no objective diagnostic confirmation described. Where deaths were attributed to $\mathrm{PE}$, postmortem examinations were not mentioned. For this reason, the results should be interpreted with caution. The RR was 1.00 (95\% Cl 0.33 to 3.05; Analysis 1.6).

\section{Outcome 7: post-thrombotic syndrome (PTS) (intermediate and late)}

Three studies reported clinically assessed PTS at six months to 5 years (intermediate) (Elliot 1979; Enden 2011; Schweizer 1998), excluding ulceration, in a format that could be combined, with a total of 306 participants. Significantly less PTS occurred in those participants receiving thrombolysis (45\% incidence with RR 0.66 , $95 \% \mathrm{Cl} 0.53$ to $0.81 ; \mathrm{P}<0.0001$; moderate quality evidence; Analysis 1.7), with a number needed to treat for an additional beneficial outcome (NNTB) of five. In the control group the incidence was $96 / 146$ ( $66 \%$, ranging from $35 \%$ to $96 \%$ in different trials, which may reflect definitions and adjunctive treatments).

Two studies with 211 participants (Arneson 1978; Enden 2011), reported clinically assessed PTS at over five years (late); (RR 0.58, $95 \% \mathrm{Cl} 0.45$ to $0.77 ; \mathrm{P}<0.0001$; moderate quality evidence; Analysis 1.8). In the control group the incidence was $72 / 107$ and in the thrombolysis group 41/104. The NNTB at late follow-up was four.

\section{Outcome 8: leg ulceration (intermediate and late)}

Four studies described ulceration of the leg occurring more than six months from trial entry (Elliot 1979; Enden 2011; Schulman 1986; Schweizer 1998). Three events occurred in the treatment group and two in the control group out of 342 participants, giving a RR 0.87 (95\% Cl 0.16 to 4.73; Analysis 1.9).This was not statistically significant $(P=0.87)$.

Arneson 1978 reported at a mean of 6.5 years and so fell within the definition of late ulceration. Events were more likely with late follow-up, with $3 / 18$ control participants experiencing ulceration after six years compared to $0 / 17$ in the thrombolysis participants (RR 0.15, 95\% Cl 0.01 to 2.72; $\mathrm{P}=0.20$; Analysis 1.10 ).

\section{Outcome 9: complete clot lysis (intermediate and late)}

Seven trials with a total of 630 participants reported clot lysis after six months and in all cases this was more likely in the groups treated with thrombolysis (Common 1976; Elliot 1979; Elsharawy 2002; Enden 2011; Schulman 1986; Schweizer 1998; Schweizer 2000). This was statistically significant with a RR of $2.44 ; 95 \% \mathrm{Cl} 1.40$ to 4.27 ; P $=0.002$ using a random-effects model (moderate quality evidence; Analysis 1.11).

Two trials with a total of 206 participants reported clot lysis at five years and over (Arneson 1978; Enden 2011). Clot lysis was not significantly more likely with thrombolysis at this time point (RR $3.25,95 \% \mathrm{Cl} 0.17$ to 62.63 ; Analysis 1.12 ).

\section{Outcome 10: mortality (intermediate and late)}

Two trials with a total of 289 participants reported mortality occurring up to five years after treatment (Elliot 1979; Schweizer 2000). Elliot 1979 reported 4 deaths in each group. Most deaths were unrelated to the clot or treatment but rather to underlying conditions. The RR was 0.96 (95\% Cl 0.27 to 3.43; Analysis 1.13), however there was wide uncertainty around the true effect.

Two trials with a total of 230 participants reported mortality after five years follow-up (Arneson 1978; Enden 2011). Seven deaths occurred in the thrombolysis group and 12 in the control group with a RR of 0.61 ( $95 \%$ Cl 0.25 to 1.50; Analysis 1.14); again with no significant difference detected.

\section{Outcome 11: normal venous function (intermediate)}

Three trials reported on presence of normal venous function (Elsharawy 2002; Enden 2011; Schulman 1986). The RR was 2.18 (95\% $\mathrm{Cl} 0.86$ to 5.54; Analysis 1.15) using a random-effects model.

\section{Outcome 12: recurrent venous thromboembolism (DVT/VTE, intermediate and late)}

One trial reported on recurrent DVT (Arneson 1978). Four events occurred in the treatment group compared to three in the control group. The RR was 1.41 ( $95 \% \mathrm{Cl} 0.37$ to 5.40 ); the numbers were too small to draw any firm conclusion. At five year follow-up Enden 2011 showed a non-significant reduction in recurrent VTE (RR 0.63, 95\% $\mathrm{Cl} 0.34$ to 1.18; Analysis 4.14).

\section{Outcome 13: quality of life}

Only Enden 2011 has reported on this outcome (Enden 2013a; Haig 2016). As this was a study using CDT, we have reported the details within comparison four.

\section{Outcome 14: cost comparisons}

Only Enden 2011 has reported on this outcome (Enden 2013b). As this was a study using CDT, we have reported the details within comparison four.

We carried out sensitivity analyses for all outcomes where the metaanalysis included trials judged to have any domain at high risk of bias (Kakkar 1969; Marder 1977; Tsapogas 1973). To determine if results were robust, analyses were repeated excluding these studies. Forest plots and summary figures were visually assessed and for all outcomes the results remained consistent. 


\section{Comparison 2. Systemic thrombolysis versus control}

Fifteen trials compared systemic thrombolysis to control (Arneson 1978; Common 1976; Elliot 1979; Goldhaber 1990; Goldhaber 1996; Kakkar 1969; Kiil 1981; Marder 1977; Schulman 1986; Schweizer 1998; Schweizer 2000; Tsapogas 1973; Turpie 1990; Ugurlu 2002; Verhaeghe 1989).

\section{Outcome 1: any improvement in venous patency (early)}

Eight trials reported on this outcome and a significant improvement in patency was demonstrated (Arneson 1978; Common 1976; Goldhaber 1990; Goldhaber 1996; Kakkar 1969; Kiil 1981; Turpie 1990; Ugurlu 2002). The RR was 2.18 (95\% Cl 1.28 to 3.70, $\mathrm{P}=0.004$; Analysis 2.1) using a random-effects model.

\section{Outcome 2: complete clot lysis (early)}

Seven trials reported a significant improvement in clot lysis (Common 1976; Elliot 1979; Goldhaber 1990; Kakkar 1969; Schulman 1986; Schweizer 2000; Ugurlu 2002), with a RR of 4.37 $(95 \% \mathrm{Cl} 1.4$ to $13.61, \mathrm{P}=0.01$; Analysis 2.2$)$ using a random-effects model.

\section{Outcome 3: bleeding (early)}

Fifteen trials reported on the occurrence of bleeding episodes (Arneson 1978; Common 1976; Elliot 1979; Goldhaber 1990; Goldhaber 1996; Kakkar 1969; Kiil 1981; Marder 1977; Schulman 1986; Schweizer 1998; Schweizer 2000; Tsapogas 1973; Turpie 1990; Ugurlu 2002; Verhaeghe 1989). Bleeding complications were twice as likely in the thrombolysis group with a RR of $2.18(95 \% \mathrm{Cl} 1.37$ to $3.47, \mathrm{P}=0.001$; Analysis 2.3).

\section{Outcome 4: stroke or intracerebral haemorrhage (early)}

Three trials reported the occurrence of stroke or intracerebral haemorrhage (Common 1976; Goldhaber 1990; Marder 1977). There were three events in the treatment group but this was not statistically significant (RR $1.92,95 \% \mathrm{Cl} 0.34$ to $10.86, \mathrm{P}=0.46$; Analysis 2.4). All trials described bleeding complications, therefore the absence of mention of any serious neurological complications or cerebral bleeds was taken to indicate that none were detected.

\section{Outcome 5: mortality (early)}

Eight trials reported deaths occurring up to one month after treatment (Arneson 1978; Common 1976; Elliot 1979; Kakkar 1969; Kiil 1981; Marder 1977; Schulman 1986; Schweizer 2000); one trial reported that no deaths occurred in this period (Schweizer 2000). A total of five events occurred in the treatment group and seven in the control group, out of a total of 394 participants. There were relatively few events and this result was not statistically significant (RR 0.76; $95 \% \mathrm{Cl} 0.31$ to $1.89, \mathrm{P}=0.56$; Analysis 2.5 ).

\section{Outcome 6: pulmonary embolus (PE) (early)}

Five trials reported occurrence of a PE in the early phase (Arneson 1978; Elliot 1979; Kakkar 1969; Schulman 1986; Schweizer 2000). There was an increase, affected by nine events in the Schweizer 2000 trial, but this was not statistically significant (RR 1.73;95\% Cl 0.55 to $5.40, \mathrm{P}=0.35$; Analysis 2.6).
Outcome 7: post-thrombotic syndrome (PTS, intermediate and late)

Two studies with 117 participants reported this outcome from six months to under five years from treatment (Elliot 1979; Schweizer 1998 ) with a reduction of almost $50 \%$ in the treatment group (RR $0.56,95 \% \mathrm{Cl} 0.30$ to 1.03 ; Analysis 2.7).

Arneson 1978 reported at a late time point also with a reduction of about $50 \%$ in the treatment group (RR $0.47,95 \% \mathrm{Cl} 0.18$ to 1.25 ; Analysis 2.8), but with a wide uncertainty around the true effect. Only 35 participants were included in this study.

\section{Outcome 8: leg ulceration (intermediate and late)}

Three studies with a total of 153 participants described ulceration of the leg occurring more than six months from trial entry (Elliot 1979; Schulman 1986; Schweizer 1998).There were similar events between the two groups but the number of events was small (RR $0.87,95 \% \mathrm{Cl} 0.16$ to $4.73 ; \mathrm{P}=0.87$; Analysis 2.9). Arneson 1978 described ulceration after five years with the three events all in the control group (RR $0.15,95 \% \mathrm{Cl} 0.01$ to $2.72 ; \mathrm{P}=0.2$; Analysis 2.10 ). Numbers are too small to draw conclusions.

\section{Outcome 9: complete clot lysis (intermediate and late)}

Five trials with a total of 300 participants reported effects on clot lysis six months from treatment (Common 1976; Elliot 1979; Schulman 1986; Schweizer 1998; Schweizer 2000). Complete lysis was nearly two and a half times as likely in the treatment group (RR $2.59,95 \% \mathrm{Cl} 1.27$ to 5.28 ; using a random-effects model $\mathrm{P}=0.009$; Analysis 2.11).

Only Arneson 1978 reported late data and all patients with complete clot lysis were within the treatment group (RR 3.25, 95\% $\mathrm{Cl} 0.17$ to $62.63 ; \mathrm{P}=0.05$; Analysis 2.12). At this time point numbers are too small to draw conclusions.

\section{Outcome 10: mortality (intermediate and late)}

Two studies with a total of 189 participants reported on this outcome at six months follow-up (Elliot 1979; Schweizer 2000). Only Arneson $1978(n=42)$ reported mortality after five years. There was no significant difference between the two groups (RR $0.96,95 \% \mathrm{Cl}$ 0.27 to 3.43; Analysis 2.13) at intermediate or late follow-up (RR $1.33,95 \% \mathrm{Cl} 0.34$ to 5.24 ; Analysis 2.14).

\section{Outcome 11: normal venous function (intermediate)}

This was only reported by Schulman 1986 (RR 1.04; 95\% Cl 0.59 to 1.83; Analysis 2.15).

\section{Outcome 12: recurrent DVT (intermediate and late)}

This was only reported by Arneson 1978 at late follow-up (RR 1.41; $95 \% \mathrm{Cl} 0.37$ to 4.40 ; Analysis 2.16).

As for Comparison 1, we carried out sensitivity analyses for all outcomes where the meta-analysis included trials judged to have any domain at high risk of bias (Kakkar 1969; Marder 1977; Tsapogas 1973). To determine if the results were robust, analyses were repeated excluding these studies. Forest plots and summary figures were visually assessed and for all outcomes the results remained consistent. 


\section{Comparison 3. Loco-regional thrombolysis versus control}

Two trials compared loco-regional thrombolysis to control (Schweizer 1998; Schweizer 2000).

\section{Outcome 1: complete clot lysis (early)}

This was reported by Schweizer 2000, who reported a marked effect (RR 10; $95 \% \mathrm{Cl} 1.33$ to 75.23 ).

\section{Outcome 2: bleeding (early)}

Both Schweizer 1998 and Schweizer 2000 reported on this outcome. Based on three events, bleeding was more likely in the treatment group (RR 4.0; $95 \% \mathrm{Cl} 0.46$ to $34.75, \mathrm{P}=0.21$ ).

\section{Outcome 3: stroke or intracerebral haemorrhage (early)}

No events occurred in either the Schweizer 1998 or Schweizer 2000 trials.

\section{Outcome 4: mortality (early)}

No events occurred in the Schweizer 2000 trial and Schweizer 1998 did not report on this outcome.

\section{Outcome 5: pulmonary embolus (PE) (early)}

No events occurred in the Schweizer 2000 trial and Schweizer 1998 did not report on this outcome.

\section{Outcome 6: post-thrombotic syndrome (PTS) (intermediate)}

This was reported by Schweizer 1998 only. A total of 11 participants in the treatment group and 17 in the control group, out of a total of 44 participants, were reported to have PTS (RR 0.65; 95\% Cl 0.40 to 1.04$)$.

\section{Outcome 7: leg ulceration (intermediate)}

This was reported by Schweizer 1998 only. One participant in each group developed leg ulcers (RR 1.00; $95 \% \mathrm{Cl} 0.07$ to 15.00).

\section{Outcome 8: complete clot lysis (intermediate)}

Both trials (Schweizer 1998; Schweizer 2000) demonstrated significant improvement ( $\mathrm{RR} 2.25 ; 95 \% \mathrm{Cl} 1.33$ to $3.80, \mathrm{P}=0.002$ ).

\section{Outcome 9: mortality (intermediate)}

Only Schweizer 2000 reported on this outcome. No events occurred.

\section{Comparison 4. Catheter-directed thrombolysis versus control}

Two trials compared CDT to control (Elsharawy 2002; Enden 2011).

\section{Outcome 1: any improvement in venous patency (early)}

This was reported only by Elsharawy 2002, with significant improvement in venous patency (RR $35.05 ; 95 \% \mathrm{Cl} 2.28$ to 539.63; $\mathrm{P}$ $=0.01$; Analysis 4.1).

\section{Outcome 2: complete clot lysis (early)}

This was reported only by Elsharawy 2002, with significant improvement (RR 21.79; $95 \% \mathrm{Cl} 1.38$ to $343 ; \mathrm{P}=0.03$; Analysis 4.2).
(3\%) and none in the control group, the RR was 7.69 (95\% $\mathrm{Cl} 0.4$ to 146.9; Analysis 4.3).

\section{Outcome 4: stroke or intracerebral haemorrhage (early)}

There were no events recorded by Elsharawy 2002 or Enden 2011. Both trials described bleeding complications, therefore the absence of mention of any serious neurological complications or cerebral bleeds was taken to indicate that none were detected.

\section{Outcome 5: mortality (early)}

There were no events recorded by Elsharawy 2002 and Enden 2011 did not report events at this time point.

\section{Outcome 6: pulmonary embolus (PE) (early)}

There was one event in the control group (RR 0.32; 95\% Cl 0.01 to 7.26) from a total of 35 participants (Elsharawy 2002). Enden 2011 did not measure this outcome at this time point.

\section{Outcome 7: post-thrombotic syndrome (PTS) (intermediate and late)}

Elsharawy 2002 did not report on this outcome. The RR of PTS at six months was reported by Enden 2011 to be $0.93(95 \% \mathrm{Cl} 0.61$ to 1.42). At 24 months the number of events in both the treatment and control groups had risen from 27 to 37 and 32 to 55 respectively; the RR was 0.74 ( $95 \% \mathrm{Cl} 0.55$ to $1.00 ; \mathrm{P}=0.05$; Analysis 4.7), close to being statistically significant. At five year late follow-up Enden 2011 reported that the number of events in the treatment group remained at 37 and those in the control group had risen to 63 . The RR was 0.6 (95\% $\mathrm{Cl} 0.45$ to $0.79 ; \mathrm{P}=0.0003$; Analysis 4.8$)$.

\section{Outcome 8: leg ulceration (intermediate)}

There were no events reported by Enden 2011 and Elsharawy 2002 did not report on this outcome.

\section{Outcome 9: complete clot lysis (intermediate and late)}

Both Enden 2011 and Elsharawy 2002 reported on complete clot lysis at the intermediate time point, with a total of 224 participants. Complete clot lysis was more likely in the treatment group although the difference was not statistically significant using a randomeffects model ( $R R 2.52,95 \% \mathrm{Cl} 0.52$ to $12.17, \mathrm{P}=0.25$; moderate quality evidence; Analysis 4.10). By late follow-up Enden 2011 reported similar numbers of complete lysis $(68 / 86$ and $61 / 86$ in treatment and control respectively; RR $1.11,95 \% \mathrm{Cl} 0.94$ to 1.33 ; Analysis 4.11).

\section{Outcome 10: mortality (intermediate and late)}

Elsharawy 2002 did not report on mortality and Enden 2011 reported mortality after five years follow-up. Three deaths occurred in the CDT group (3/90), compared to nine in the control group (9/98; RR 0.36, 95\% Cl 0.10 to 1.30; Analysis 4.15).

\section{Outcome 11: normal venous function (intermediate)}

This was reported by Elsharawy 2002 and Enden 2011 and pooling of results showed a significant improvement with treatment (RR $2.98,95 \% \mathrm{Cl} 1.75$ to 5.08 ) (Analysis 4.12 ).

\section{Outcome 3: bleeding (early)}

Both Enden 2011 and Elsharawy 2002 reported on this with a total of 224 participants. Based on three events in the treatment group 
Outcome 12: recurrent venous thromboembolism (VTE) (intermediate and late)

While DVT was not reported separately, intermediate recurrent VTE was reported by Enden 2011 (RR 0.61; 95\% Cl 0.30 to 1.25; Analysis 4.13). At five year follow-up Enden 2011 reported that 34 patients had recurrent thrombosis. Thirteen events were in the ipsilateral leg, 10 in the contralateral leg, nine were PE and two were unknown (RR $0.63,95 \% \mathrm{Cl} 0.34$ to 1.18; Analysis 4.14). Six patients with chronic iliac vein occlusions (one in the CDT group and five in the control group), were referred and had endovascular recanalsation with stenting. Although randomised to the treatment group, the CDT patient had not received CDT as planned due to technical failure (Haig 2016).

\section{Outcome 13: quality of life}

Enden 2011 was the only study to report on this outcome, using generic QoL measures (VEINES-QOL) and symptom specific (VEINES-Sym) scales. After 24 months there were no differences in QoL between the additional CDT and standard treatment arms; mean difference for the EQ-5D index was $0.04(95 \% \mathrm{Cl}-0.10$ to 0.17$)$, for the VEINES-QOL score $0.2(95 \% \mathrm{Cl}-2.8$ to 3.0$)$ and for the VEINESSym score $0.5(95 \% \mathrm{Cl}-2.4$ to $3.4 ; \mathrm{P}$ value $>0.37)$. After 5 years Enden 2011 reported no difference in mean generic QoL scores, disease specific QoL scores, or symptom severity score between the groups (see Enden 2012; Enden 2013a).

Independent of treatment arms, after 24 months patients with PTS had poorer outcomes than patients without PTS; mean difference for EQ-5D was 0.09 (95\% Cl 0.03 to 0.15), for VEINES-QOL score 8.6 $(95 \% \mathrm{Cl} 5.9$ to 11.2$)$ and for VEINES-Sym score $9.8(95 \% \mathrm{Cl} 7.3$ to 12.3; $P$ value $<0.001$ ). After five years the EQ-5D, VEINES-QOL and VEINES-Sym scores for patients with PTS were lower than for those without PTS (Enden 2012; Enden 2013a).

\section{Outcome 14: cost comparisons}

Cost comparisons were only reported by Enden 2011. Additional CDT accumulated 32.31 quality-adjusted life years (QALYS) compared with 31.68 QALYs after standard treatment. The lifetime cost of CDT was USD 64,709 compared to USD 51,866 with standard treatment. The incremental cost effectiveness ratio was USD 20,429/QALY gained, and the study authors concluded that the probability that CDT was cost effective was $82 \%$ at a willingness to pay threshold of USD 50,000/QALY gained (Enden 2013b). CDT may have additional costs compared to systemic administration.

\section{DISCUSSION}

\section{Summary of main results}

The rationale for the use of thrombolysis for DVT is to prevent longterm complications related to poor venus function including PTS and ulceration. For this update it is encouraging that further data on intermediate to longer-term outcomes are available to assess these complications. Sixty-six per cent of control participants at intermediate time points and sixty-seven per cent at late follow-up experienced PTS, which is in line with other estimates. Pooling all types of thrombolysis, the results showed a reduction in the risk of PTS with use of thrombolysis by $34 \%$ at the intermediate time point (RR 0.66; NNTB 5) and a reduction in the risk of PTS of $42 \%$ at late follow-up (RR 0.58; NNTB 4). There was no difference in ulceration beyond six months; data were limited by small numbers and the short length of follow-up, as ulcers are more likely to occur later than a year or two after the DVT.

CDT has been studied at the femoral and iliofemoral levels only, where the risk of post-thrombotic complications is highest. Comparison four shows the results for the two recent trials which studied this method, which are comparable to the results for all routes of thrombolysis combined.

There were not enough data in this review to make any definitive comparison between the different agents or routes of administration for thrombolysis. Streptokinase appears to have been most widely studied. Significant results were obtained by combining studies including participants with DVT at a variety of levels of the leg veins affected, while it is accepted that the likelihood of later complications is less with clots at lower levels (Table 1).

The most marked effects with thrombolysis were seen in improvement in vein patency and complete clot lysis measured by venography, where both early and intermediate results showed important differences between the control and treatment groups. The use of objective classification of the degree of lysis would assist, in the future, with quantifying this outcome and the patency of the veins. There were not enough data to comment further on venous function or recurrent DVT per se. Results relating to PE were inconclusive due to uncertainty surrounding diagnosis.

The risk of inducing unwanted bleeding with thrombolytics has been the most important factor limiting its use for patients with DVT. Most bleeding episodes and deaths occurred in the earlier studies. Bleeding episodes (excluding stroke) causing interruption of therapy, interventions such as transfusion, or chronic sequelae (a condition following as a consequence of a disease) occurred more often with thrombolysis than with standard anticoagulation (RR 2.23; NNTH 17). There is no strong evidence that one particular route of administration or agent was excessively hazardous in this respect, although it is notable that no bleeding occurred in the Elsharawy 2002 study. This may have been due to strict exclusion criteria and the close radiological monitoring and dose titration depending upon clot lysis. A high proportion of patients with DVT are, however, unsuitable for thrombolytic treatment because of extensive contra-indications.

Three intracerebral bleeds occurred in these trials (Common 1976; Goldhaber 1990; Marder 1977). Adoption of current contraindications may have prevented these events in more recent trials. A stroke occurred in a participant with polycythaemia rubra vera who received streptokinase (Common 1976), an intracranial bleed in a participant with controlled hypertension treated with tPA(Goldhaber 1990), and a fatal intracranial haemorrhage in a patient with a remote history of cerebrovascular accident (Marder 1977). Two of the early deaths in the treatment groups may also have been prevented with the use of current contra-indications to thrombolysis: a participant with metastatic carcinoma (Common 1976), and a participant with recent surgery (Kakkar 1969). Other deaths were incidental to the treatment or related to underlying conditions.

The data on intermediate mortality were inconclusive. One trial (Schweizer 2000) reported the absence of further PE episodes at one year, however no other trials reported on this outcome. Other 
adverse effects, for example allergic or anaphylactic reactions, were not examined in this review.

No comparisons between thrombolysis and subcutaneous low molecular weight heparin, administered at home, for DVT were identified.

One study Enden 2011 examined both QoL and cost effectiveness. For QoL there was no significant difference between CDT and standard treatment although PTS was associated with a lower QoL. The incremental cost effectiveness ratio was USD 20,429 per QALY gained (Enden 2013b). This incremental cost effectiveness ratio for CDT is within the range for approval by bodies making recommendation for implementation (Dakin 2014; NICE PMG9).

\section{Overall completeness and applicability of evidence}

The evidence presented is highly relevant to determining the effect of thrombolysis for DVT. The effectiveness of newer catheterdirected methods appears to be similar to systemic administration. Evidence suggests effectiveness at levels not limited to iliofemoral. As there is a degree of consistency in the results of trials over time, and in different settings, it is likely that the findings have external validity. Further evidence is desirable to confirm the effect of newer methods, and the factors predicting more successful outcomes. In future a combination of invasive procedures to remove the clot, with or without thrombolysis, may increase the proportion of patients who have effective clot removal; but that was out of the scope of this review. With respect to standard treatment with anticoagulation, selected patients may benefit from additional thrombolysis directed by catheter, or systemic if this were considered safe. This is in keeping with the current 'Recommendations and link to evidence' from NICE guidelines (NICE guidelines CG144). There are implications for inpatient treatment, where anticoagulation for DVT is now delivered in outpatient settings, and for the resourcing of more invasive procedures.

\section{Quality of the evidence}

This evidence is based on 17 trials involving 1103 participants from a range of countries and settings. The key limitation of the studies is the paucity of long-term follow-up data greater than one year. The methodological quality of the studies was mostly high, and the results were consistent across a range of settings and patient groups. Using GRADE assessment, the body of evidence relating to complete clot lysis (intermediate), bleeding (early) and PTS (intermediate and late) was judged to be of moderate quality due to many trials having low numbers of participants (See Summary of findings for the main comparison; Summary of findings 2). There were obvious differences between the inclusion criteria and the conduct of studies completed over 40 years ago compared to more recent studies. However, the results across studies were consistent and we have reasonable confidence in the results.

\section{Potential biases in the review process}

It is likely that all relevant studies were identified and included. Relevant data were requested or obtained from study authors, although for older studies this was less likely to be successful. Efforts were made to reduce bias in the review process by ensuring double independent data extraction and quality assessment of studies.

\section{Agreements and disagreements with other studies or reviews}

The evidence presented here is consistent with findings of other reviews, which have included a broader range of evidence than RCTs. A review of the literature by Patterson 2010 concluded that in carefully selected patients CDT offered benefits in treatment, although further trial evidence was needed. Vedantham 2010 indicated benefits in CDT for people with extensive acute iliofemoral DVT, low expected bleeding risk and good functional status, although Comerota 2008 also emphasised a need for further research. A meta-analysis by Du 2015 included both randomised and non-randomised studies and had similar findings. Systemic thrombolysis is not current practice although this review suggests that it has similar effectiveness to CDT.

\section{AUTHORS' CONCLUSIONS}

\section{Implications for practice}

Thrombolysis offers potential advantages over standard treatment for DVT, by reducing the proportion of patients with chronic disabling leg symptoms from PTS by a third up to and beyond five years from treatment. This finding is based on four trials with a total of 341 participants, most of which have low risk of bias. There was an increased risk of iatrogenic (resulting from medical treatment or procedures) bleeding, but this risk has decreased over time with the use of stricter exclusion criteria for thrombolysis.

Results from systemic thrombolysis and CDT appear similar. Evidence suggests effectiveness for DVT above the level of the calf. Patients with extensive thromboses, for example iliofemoral, may have the most to gain in terms of preserving venous function, and patient selection is important to reduce the risk of complications. It was not possible to determine the optimum treatment regime in terms of agent, dose and route of administration from this review. Cost analysis from one study suggests that the incremental cost effectiveness ratio for CDT is within the range for approval by bodies making recommendation for implementation.

\section{Implications for research}

Future trials need to be large enough to detect significant clinical outcomes and ideally last two to five years to estimate the long-term effect of thrombolysis. CDT differs significantly, as a technique, from systemic thrombolysis and further investigation is needed using this method, particularly in the long term. It may worth be re-visiting whether systemic thrombolysis can be used safely in the modern era with careful patient selection. There are also resource implications to introducing systemic or CDT in selected patients due to the need for availability of skilled staff and interventional resources. Access to such treatment where outpatient management of DVT is undertaken may require service changes and these factors will require appropriate consideration in health economic studies which assess costs and cost effectiveness.

Use of thrombolysis in combination with interventional methods of clot removal may offer benefit to a wider group of patients, and the effect of temporary inferior vena cava filtration within this is an area for study. Newer agents that cause less systemic bleeding may hold promise for this condition.

It may be useful to differentiate the effects of PTS and thrombolysis on younger and older patients, the specific level of the clot, and 
differing times from the initial event, for example 14 days or 21 days or sooner from symptom onset. The measurement and quantification of lysis and the resulting patency of the vein is an area for further study. Exclusions, such as malignancy, warrant further study as these may become less significant in certain circumstances with safer methods of treatment. One of the studies performed a cost analysis and examined quality of life issues, but these too need further research.

\section{ACKNOWLEDGEMENTS}

We would like to thank $\mathrm{Dr}$ Jonathon Michaels who was involved with formulating the original protocol. 


\section{R E F E R E N C E S}

\section{References to studies included in this review}

\section{Arneson 1978 \{published data only\}}

Arnesen $\mathrm{H}$. The late results of treatment with streptokinase or heparin in patients with acute deep vein thrombosis. Thrombosis and Haemostasis 1983;50(1):329-Abstract No. 1039.

* Arnesen H, Heilo A, Jakobsen E, Ly B, Skaga E. A prospective study of streptokinase and heparin in the treatment of deep vein thrombosis. Acta Medica Scandinavica 1978;203(6):457-63.

Arnesen $\mathrm{H}$, Hoiseth A, Ly B. Streptokinase of heparin in the treatment of deep vein thrombosis. Follow-up results of a prospective study. Acta Medica Scandinavica 1982;211(1-2):65-8.

\section{Common 1976 \{published data only\}}

* Common HH, Seaman AJ, Rosch J, Porter JM, Dotter CT. Deep vein thrombosis treated with streptokinase or heparin. Followup of a randomized study. Angiology 1976;27(11):645-54.

Porter JM, Seaman AJ, Common HH, Rosch J, Eidemiller LR, Calhoun AD. Comparison of heparin and streptokinase in the treatment of venous thrombosis. American Surgeon 1975;41(9):511-9.

Rosch J, Dotter CT, Seaman AJ, Porter JM, Common HH. Healing of deep venous thrombosis: venographic findings in a randomized study comparing streptokinase and heparin. American Journal of Roentgenology 1976;127(4):553-8.

Seaman AJ, Common HH, Rosch J, Dotter CT, Porter JM, Lindell TD, et al. Deep vein thrombosis treated with streptokinase or heparin. A randomized study. Angiology 1976;27(10):549-56.

\section{Elliot 1979 \{published data only\}}

Elliott MS, Immelman EJ, Jeffery P, Benatar SR, Funston MR, Smith JA, et al. A comparative randomized trial of heparin versus streptokinase in the treatment of acute proximal venous thrombosis: an interim report of a prospective trial. British Journal of Surgery 1979;66(12):838-43.

\section{Elsharawy 2002 \{published data only\}}

Elsharawy M, Elzayat E. Early results of thrombolysis vs anticoagulation in iliofemoral venous thrombosis. A randomised clinical trial. European Journal of Vascular and Endovascular Surgery 2002;24(3):209-14.

\section{Enden 2011 \{published data only\}}

Enden T, Haig Y, Holme G. Long-term outcome after additional catheter-directed thrombolysis versus standard treatment for acute iliofemoral deep vein thrombosis (the CaVenT study): a randomised controlled trial. Lancet 2012;379(9810):31-8.

Enden T, Klow NE, Sandvik L, Slagsvold CE, Ghanima W, Hafsahl G, et al. Catheter-directed thrombolysis vs. anticoagulant therapy alone in deep vein thrombosis: results of an open randomized, controlled trial reporting on shortterm patency. Journal of Thrombosis and Haemostasis 2009;7(8):1268-75
Enden T, Sandvik L, Klow NE, Hafsahl G, Holme PA, Holmen LO, et al. Catheter-directed Venous Thrombolysis in acute iliofemoral vein thrombosis-the CaVenT Study: rationale and design of a multicenter, randomized, controlled, clinical trial (NCT00251771). American Heart Journal 2007;154(5):808-14.

* Enden TR, Haig Y, Kløw NE, Slagsvold CE, Sandvik L, Ghanima W, et al. Improved functional outcome after additional catheter-directed thrombolysis for acute iliofemoral deep vein thrombosis: results of a randomized controlled clinical trial (the CaVenT study). Blood 2011;118(21):LBA-1.

Enden TR, Resch S, White C, Wik HS, Klow NE, Sandset PM. Costeffectiveness of additional catheter-directed thrombolysis for deep vein thrombosis. Journal of Thrombosis and Haemostasis 2013;11:442.

Enden TR, Resch S, White C, Wik HS, Klow NE, Sandset PM. Health-related quality of life after catheter-directed thrombolysis for deep vein thrombosis: Secondary outcomes of the randomised, non-blinded, parallel-group CaVenT study. BMJ Open 2013;3(8):e002984.

Enden TR, Slagsvold CE, Klow NE, Sandset PM. Additional catheter-directed venous thrombolysis in iliofemoral deep vein thrombosis; short-term results from the cavent study, a multicenter, randomized controlled trial. Journal of Thrombosis and Haemostasis 2009; Vol. 7 Suppl 2:Abstract no: AS-MO-007.

Enden TR, Slagsvold CE, Klow NE, Sandset PM. Adjunctive catheter-directed venous thrombolysis in iliofemoral deep vein thrombosis; short-term results from the CaVenT study, a multicenter randomized controlled trial [Abstract No. 989]. Blood 2008;112(11):365.

Enden TR, Wik HS, Kvam AK, Haig Y, Klow NE, Sandset PM. Health-related quality of life after catheter-directed thrombolysis for deep vein thrombosis; from the CaVenT study. Journal of Thrombosis and Haemostasis 2013;11:29-30.

Haig Y, Enden T. Additional catheter-directed thrombolysis for high proximal deep vein thrombosis; 5 year results of a randomized controlled trial (the CaVenT Study). Journal of Thrombosis and Haemostasis. 2015; Vol. 13:49.

Haig Y, Enden T, Grøtta O, Kløw NE, Slagsvold CE, Ghanima W, et al. Post-thrombotic syndrome after catheter-directed thrombolysis for deep vein thrombosis (CaVenT): 5-year followup results of an open-label, randomised controlled trial. Lancet Haematology 2016;3(2):e64-e71.

Haig Y, Enden T, Slagsvold CE, Sandvik L, Sandset P, Kløw NE. Residual rates of reflux and obstruction and their correlation to post-thrombotic syndrome in a randomized study on catheter-directed thrombolysis for deep vein thrombosis. Journal of Vascular Surgery and Venous Lymphatic Disorders 2014;2(2):123-30.

Haig Y, Enden T, Slagsvold CE, Sandvik L, Sandset PM, Klow NE, et al. Five-year outcome after catheter-directed thrombolysis for upper femoral and/or iliac vein thrombosis: results of a 
randomized controlled trial (the CaVenT Study). Cardiovascular and Interventional Radiology. 2016; Vol. 38:S193.

Haig Y, Enden T, Slagsvold CE, Sandvik L, Sandset PM, Kløw NE. Determinants of early and long-term efficacy of catheterdirected thrombolysis in proximal deep vein thrombosis. Journal of Vascular and Interventional Radiology 2013;24:17-24.

NCT00251771. CaVenT: Catheter-directed venous thrombolysis in acute iliofemoral vein thrombosis--the CaVenT study: rationale and design of a multicenter, randomized, controlled, clinical trial (NCT00251771). http://clinicaltrials.gov/ct/show/ NCT00251771? order=1 2007 (accessed 21 June 2016).

Sandset PM. Catheter-directed thrombolysis reduced the postthrombotic syndrome in acute iliofemoral DVT. Annals of Internal Medicine 2012;156(12):31-8.

Goldhaber 1990 \{published data only\}

* Goldhaber SZ, Meyerovitz MF, Green D, Vogelzang RL, Citrin P, Heit J, et al. Randomized controlled trial of tissue plasminogen activator in proximal deep venous thrombosis. American Journal of Medicine 1990;88(3):235-40.

Green D, Goldhaber S, Meyerovitz MF, Citrin P, Vogelzang R, Heit J, et al. A multicenter trial of recombinant human tissuetype plasminogen activator (Activase) in proximal deep vein thrombosis. Thrombosis and Haemostasis 1989;62(1):406Abstract No 1289.

\section{Goldhaber 1996 \{published data only\}}

Goldhaber SZ, Hirsch DR, MacDougall RC, Polak JF, Creager MA. Bolus recombinant urokinase versus heparin in deep venous thrombosis: a randomized controlled trial. American Heart Journal 1996;132(2 Pt 1):314-8.

\section{Kakkar 1969 \{published data only\}}

Kakkar VV. Results of streptokinase therapy in deep venous thrombosis. Postgraduate Medical Journal 1973;Suppl:60-4.

Kakkar VV, Flanc C, Howe CT, O'Shea M, Flute PT. Treatment of deep vein thrombosis. A trial of heparin, streptokinase and arvin. British Medical Journal 1969;1(647):806-10.

Kakkar VV, Flanc C, O'Shea M, Flute P, Howe CT, Clarke MB. Treatment of deep-vein thrombosis - a random trial. British Journal of Surgery 1968;55(11):858.

* Kakkar VV, Howe CT, Laws JW, Flanc C. Late results of treatment of deep vein thrombosis. British Medical Journal 1969;1(5647):810-1.

\section{Kiil 1981 \{published data only\}}

Kiil J, Carvalho A, Sakso P, Nielsen HO. Urokinase or heparin in the management of patients with deep vein thrombosis?. Acta Chirurgica Scandinavica 1981;147(7):529-32.

Marder 1977 \{published data only\}

Marder VJ, Soulen RL, Atichartakarn V, Budzynski AZ, Parulekar S, Kim JR, et al. Quantitative venographic assessment of deep vein thrombosis in the evaluation of streptokinase and heparin therapy. Journal of Laboratory and Clinical Medicine 1977;89(5):1018-29.
Schulman 1986 \{published data only\}

Schulman S, Granqvist S, Juhlin-Dannfelt A, Lockner D. Long-term sequelae of calf vein thrombosis treated with heparin or low-dose streptokinase. Acta Medica Scandinavica 1986;219(4):349-57.

\section{Schweizer 1998 \{published data only\}}

Schweizer J, Elix H, Altmann E, Hellner G, Forkmann L. Comparative results of thrombolysis treatment with rt-PA and urokinase: a pilot study. VASA 1998;27(3):167-71.

\section{Schweizer 2000 \{published data only\}}

Schweizer J, Kirch W, Koch R, Elix H, Hellner G, Forkmann L, et al. Short- and long-term results after thrombolytic treatment of deep venous thrombosis. Journal of the American College of Cardiology 2000;36(4):1336-43.

Tsapogas 1973 \{published data only\}

Tsapogas MJ, Peabody RA, Wu KT, Karmody AM, Devaraj KT, Eckert C. Controlled study of thrombolytic therapy in deep vein thrombosis. Surgery 1973;74(6):973-84.

\section{Turpie 1990 \{published data only\}}

Hirsh J. Thrombolytic therapy for venous thrombosis and pulmonary embolism. Thrombosis and Haemostasis 1989;62(1):547-Abstract No 1739.

* Turpie AG, Levine MN, Hirsh J, Ginsberg JS, Cruickshank M, Jay $R$, et al. Tissue plasminogen activator (rt-PA) vs heparin in deep vein thrombosis. Results of a randomized trial. Chest 1990;97(4 Suppl):172S-5S.

Ugurlu 2002 \{published data only\}

Ugurlu B, Kazaz H, Oto O, Hazan E, Sariosmanolu N. Low dose systemic thrombolytic therapy for treatment of deep venous thrombosis. Journal of Cardiovascular Surgery 2002;43(6):881-5.

\section{Verhaeghe 1989 \{published data only\}}

Verhaeghe R, Besse P, Bounameaux H, Marbet GA. Multicenter pilot study of the efficacy and safety of systematic rt-PA administration in the treatment of deep vein thrombosis of the lower extremities and/or pelvis. Thrombosis Research 1989;55(1):5-11.

\section{References to studies excluded from this review}

\section{Ansell 1990 \{published data only\}}

Ansell JE, Repice NI, Klassen VA. Treatment of deep venous thrombosis (DVT) with a 5-day low-dose infusion of tissue plasminogen activator (rt-PA). Arteriosclerosis 1990;10:937A.

Bashir 2014 \{published data only\}

Bashir R. Comparative outcomes of catheter-directed thrombolysis plus anticoagulation vs anticoagulation alone to treat lower-extremity proximal deep vein thrombosis. JAMA Internal Medicine 2014;174(9):1494-501. 
Bieger 1976 \{published data only\}

Bieger R, Boekhout-Mussert RJ, Hohmann F, Loeliger EA. Is streptokinase useful in the treatment of deep venous thrombosis?. Acta Medica Scandinavica 1976;199(1-2):81-8.

\section{Browse 1968 \{published data only\}}

Browse NL, Thomas ML, Pim HP. Streptokinase and deep vein thrombosis. British Medical Journal 1968;3(5620):717-20.

\section{Cakir 2014 \{published data only\}}

Cakir V, Gulcu A, Akay E, Capar AE, Gencpinar T, Kucuk B, et al. Use of percutaneous aspiration thrombectomy vs. anticoagulation therapy to treat acute iliofemoral venous thrombosis: 1-year follow-up results of a randomised, clinical trial. Cardiovascular and Interventional Radiology 2014;37(4):969-76.

\section{Engelberger 2015 \{published data only\}}

Engelberger RP, Spirk D, Willenberg T, Alatri A, Do DD, Baumgartner I, et al. Ultrasound-assisted versus conventional catheter-directed thrombolysis for acute iliofemoral deep vein thrombosis. Circulation: Cardiovascular Interventions 2015;8:e002027.

\section{Johansson 1979 \{published data only\}}

Johansson L, Nylander G, Hedner U, Nilsson IM. Comparison of streptokinase with heparin: late results in the treatment of deep venous thrombosis. Acta Medica Scandinavica 1979;206(1-2):93-8.

\section{Marini 1991 \{published data only\}}

Marini M, Tovar E, Batlle J, Rodriquez E, Beraza A, Cachaza FF, et al. Local venous thrombolysis in eighty-two cases: New treatment approaches. Thrombosis and Haemostasis 1991;65(6):1132-Abstract No 1573.

\section{Markevicius 2004 \{published data only\}}

Markevicius N, Apanavicius G, Scerbinskas S. Comparison between long-term results of catheter-directed thrombolysis and anticoagulation in the treatment of acute iliofemoral deep vein thrombosis. Phlebology 2004;19(3):148-9.

\section{Patra 2014 \{published data only\}}

Patra S. Catheter directed thrombolysis along with mechanical thromboaspiration versus anticoagulation alone in the management of lower limb deep venous thrombosis - a comparative study. Journal of American College Cardiology 2014;64(16 Suppl 1):C203.

\section{Persson 1977 \{published data only\}}

Persson AV, Foti CE, Pierce LE, Sower ND. Role of streptokinase in treatment of venous thrombosis. Thrombosis et Diathesis Haemorrhagica 1977;38(1):298.

\section{Pinto 1997 \{published data only\}}

Pinto A, Corrao S, Galati D, Arnone S, Licata A, Parrinello G, et al. Sulodexide versus calcium heparin in the mediumterm treatment of deep vein thrombosis of the lower limbs. Angiology 1997;48(9):805-11.

\section{Robertson 1967 \{published data only\}}

Robertson BR, Nilsson IM, Nylander G. Thrombolytic effect of streptokinase as evaluated by phlebography of deep venous thrombi of the leg. Acta Chirurgica Scandinavica 1970;136(3):173-80.

Robertson BR, Nilsson IM, Nylander G. Value of streptokinase and heparin in treatment of acute deep venous thrombosis. A coded investigation. Acta Chirurgica Scandinavica 1968;134(3):203-8.

* Robertson BR, Nilsson IM, Nylander G, Olow B. Effect of streptokinase and heparin on patients with deep venous thrombosis. A coded examination. Acta Chirurgica Scandinavica 1967;133(3):205-15

\section{Santiago 2014 \{published data only\}}

Santiago MJ, Lopez-Herce J, Del Castillo DB. Thrombolytic therapy using a low dose of tissue plasminogen activator in children. Catheterization and Cardiovascular Interventions 2014;83(2):339-40.

\section{Sas 1985 \{published data only\}}

Sas G, Peto I. Late results of streptokinase/heparin treatment in deep venous thrombosis. Thrombosis and Haemostasis 1985;54(1):174-Abstract No 01030.

\section{Schweizer 1996 \{published data only\}}

Schweizer J, Spranger CH, Henkel A, Nirade A, Kaulen R, Altmann E. Long-term outcome after venous thrombolysis with rt-PA and urokinase [Langzeitergebnisse nach venoser thrombolyse mit rt-PA und urokinase]. Phlebologie 1996;25(5):173-6.

\section{Silistreli 2004 \{published data only\}}

Silistreli E, Bekis R, Serbest O, Arslan G, Ulker O, Catalyurek H, et al. Platelet scintigraphy results of heparin versus streptokinase treatment in acute deep vein thrombosis. Scandinavian Cardiovascular Journal 2004;38(6):380-2.

Sui 2013 \{published data only\}

Sui SG, Wang SL, Sun P, Xiao Y, Shi HF. Catheter-directed thrombolytic therapy with use of reteplase and urokinase for the treatment of acute deep venous thrombosis of lower extremity: an observation of clinical results. Journal of Interventional Radiology 2013;22(1):57-60.

Tibbutt 1974 \{published data only\}

Tibbutt DA, Williams EW, Walker MW, Chesterman CN, Holt JM, Sharp AA. Controlled trial of ancrod and streptokinase in the treatment of deep vein thrombosis of lower limb. British Journal of Haematology 1974;27(3):407-14.

Tibbutt 1977 \{published data only\}

Tibbutt DA, Chesterman CN, Williams EW, Faulkner T, Sharp AA. Controlled trial of the sequential use of streptokinase and ancrod in the treatment of deep vein thrombosis of lower limb. Thrombosis and Haemostasis 1977;37(2):222-32. 
TORPEDO 2012 \{published data only\}

* Sharifi M, Bay C, Mehdipour M, Sharifi J. Thrombus obliteration by rapid percutaneous endovenous intervention in deep venous occlusion (TORPEDO) trial: Midterm results. Journal of Endovascular Therapy 2012;2:273-80.

Sharifi M, Mehdipour M, Bay C, Smith G, Sharifi J. Endovenous therapy for deep venous thrombosis: the TORPEDO trial. Catheterization and Cardiovascular Interventions 2010;76(3):316-25.

\section{Zhang 2014 \{published data only\}}

Zhang X, Ren Q, Jiang X, Sun J, Gong J, Tang B, et al. A prospective randomized trial of catheter-directed thrombolysis with additional balloon dilatation for iliofemoral deep venous thrombosis: a single-center experience. Cardiovascular and Interventional Radiology 2014;37(4):958-68.

\section{Zimmermann 1986 \{published data only\}}

Zimmermann R, Epping J, Rasche H, Krzywanek HJ, Breddin K, Rudolph T, et al. Urokinase and streptokinase treatment of deep venous thrombosis. Results of a randomized study. Haemostasis 1986;16 Suppl 5:9.

\section{References to ongoing studies}

IRCT201108035625N3 \{published data only\}

IRCT201108035625N3. Comparing the effect of conventional therapy (Heparin followed by warfarin) with interventional therapy (thrombolysis with or without angioplasty and stenting) on venous patency in patients who admitted with acute iliofemoral DVT in Tehran Heart Center Emergency Department. Iranian Registry of Clinical Trials (accessed 11 June 2015).

\section{NCT00790335 \{published data only\}}

Comerota AJ. The ATTRACT trial: rationale for early intervention for iliofemoral DVT. Perspectives in Vascular Surgery and Endovascular Therapy 2009;21(4):221-4.

Vedantham S, Goldhaber SZ, Kahn SR, Julian J, Magnuson E, Jaff MR, et al. Rationale and design of the ATTRACT Study: A multicenter randomized trial to evaluate pharmacomechanical catheter-directed thrombolysis for the prevention of postthrombotic syndrome in patients with proximal deep vein thrombosis. American Heart Journal 2013;165(4):523-30.

\section{NCT00970619 \{published data only\}}

DUTCH CAVA-trial. Ultrasound accelerated catheter-directed thrombolysis for primary iliofemoral deep vein thrombosis (IFDVT) compared to non-invasive conventional anticoagulant therapy alone: a Dutch randomized controlled multicenter clinical trial. https://clinicaltrials.gov/ct2/show/NCT00970619 (accessed 11 June 2015).

Strijkers RHW, Ten Cate-Hoek AJ, Prins MH, Ten CH, Wittens CHA. Design of the catheter directed thrombolysis and anticoagulation therapy vs. anticoagulation alone; The Dutch cava-study; Multicenter randomized controlled trial. Journal of Thrombosis and Haemostasis 2011;9:190-1.

\section{Additional references}

\section{Atkins 2004}

Atkins D, Best D, Briss PA, Eccles M, Falck-Ytter Y, Flottorp S, et al. Grading quality of evidence and strength of recommendations. BMJ 2004;328(7454):1490-4.

\section{Brandjes 1997}

Brandjes DP, Buller HR, Heijboer H, Huisman MV, de Rijk M, Jagt $\mathrm{H}$, et al. Randomised trial of effect of compression stockings in patients with symptomatic proximal-vein thrombosis. Lancet 1997;349(9054):759-62.

\section{Browse 1999}

Browse NL, Burnand KG, Lea Thomas M. Deep vein thrombosis: pathology, diagnosis and treatment. In: Browse NL, Burnand KG, Irvine AT, Wilson NM editor(s). Diseases of the veins. 2nd Edition. London: Edward Arnold, 1999:443-74.

\section{Comerota 2008}

Comerota AJ, Gravatt MH. Current status of thrombolysis for acute deep vein thrombosis. Phlebolymphology 2008;15(3):85-93.

\section{Dakin 2014}

Dakin H, Devlin H, Parkin D, Rice N. NICE's cost-effectiveness threshold. https://www.herc.ox.ac.uk/research/nhs-ukhealthcare-system/studies/nice2019s-cost-effectivenessthreshold (accessed 20 September 2016).

\section{Du 2015}

Du GC, Zhang MC, Zhao JC. Catheter-directed thrombolysis plus anticoagulation versus anticoagulation alone in the treatment of proximal deep vein thrombosis: a meta-analysis. Vasa European Journal of Vascular Medicine 2015;44(3):195-22.

\section{Enden 2012}

Enden T, Haig Y, Holme G. Long-term outcome after additional catheter-directed thrombolysis versus standard treatment for acute iliofemoral deep vein thrombosis (the CaVenT study): a randomised controlled trial. Lancet 2012;379(9810):31-8.

\section{Enden 2013a}

Enden T, Wik HS, Kvam AK, Haig Y, Kløw NE, Sandset PM. Healthrelated quality of life after catheter-directed thrombolysis for deep vein thrombosis: Secondary outcomes of the randomised, non-blinded, parallel-group CaVenT study. BMJ Open 2013;3(8):e002984.

\section{Enden 2013b}

Enden TR, Resch S, White C, Wik HS, Klow NE, Sandset PM. Costeffectiveness of additional catheter-directed thrombolysis for deep vein thrombosis. Journal of Thrombosis and Haemostasis 2013;11(6):1032-42.

\section{Haig 2016}

Haig Y, Enden T, Grøtta O, Kløw NE, Slagsvold CE, Ghanima W, et al. Post-thrombotic syndrome after catheter-directed thrombolysis for deep Vein thrombosis (CaVenT): 5-year followup results of an open-label, randomised controlled trial. Lancet Haematology 2016;3(2):e64-e71. 


\section{Higgins 2011}

Higgins JPT, Altman DG, Sterne JAC (editors). Chapter 8: Assessing risk of bias in included studies. In: Higgins JPT, Green S editor(s). Cochrane Handbook for Systematic Reviews of Interventions Version 5.1.0 (updated March 2011). The Cochrane Collaboration, 2011. Available from www.cochranehandbook.org.

\section{Jadad 1996}

Jadad AR, Moore RA, Carroll D, Jenkinson C, Reynolds DJ, Gavaghan DJ, et al. Assessing the quality of reports of randomized clinical trials: is blinding necessary?. Controlled Clinical Trials 1996;17(1):1-12.

\section{Johnson 1995}

Johnson BF, Manzo RA, Bergelin RO, Strandness DE Jr. Relationship between changes in the deep venous system and the development of the postthrombotic syndrome after an acute episode of lower limb deep vein thrombosis: a one-to sixyear follow-up. Journal of Vascular Surgery 1995;21(2):307-12.

\section{Kahn 2004}

Kahn SR, Ginsberg JS. Relationship between deep venous thrombosis and the postthrombotic syndrome. Archives of Internal Medicine 2004;164:17-26.

\section{Kahn 2006}

Kahn SR. The post-thrombotic syndrome: progress and pitfalls. British Journal of Haematology 2006;134:357-65. [doi:10.1111/ j.1365-2141.2006.06200.]

\section{Kahn 2008}

Kahn SR, Shrier I, Julian JA, Ducruet T, Arsenault L, Miron M, et al. Determinants and time course of the post thrombotic syndrome after acute deep venous thrombosis. Annals of Internal Medicine 2008;149:698-707. [DOI: doi:10.7326/0003-4819-149-10-200811180-00004]

\section{Kearon 2016}

Kearon C, Akl EA, Ornelas J, Blaivas A, Jimenez D, Bounameaux $\mathrm{H}$, et al. Antithrombotic Therapy for VTE Disease: CHEST Guideline and Expert Panel Report. Chest 2016;149(2):315-52.

\section{NICE 2012}

National Clinical Guideline Centre. Venous thromboembolic diseases: the management of venous thromboembolic diseases and the role of thrombophilia testing. Clinical Guideline. Methods, evidence and recommendations. http:// www.nice.org.uk/guidance/cg144/evidence/cg144-venousthromboembolic-diseases-full-guideline3 (accessed 20 September 2016).

\section{NICE guidelines CG144}

National institute for Health and Care Excellence. Venous thromboembolic diseases: diagnosis, management and thrombophilia testing. https://www.nice.org.uk/guidance/ cg144/evidence (accessed 15 September 2016).

\section{NICE PMG9}

NICE Appraisal Committee. Guide to the methods of technology appraisal (PMG9). https://www.nice.org.uk/process/pmg9/ chapter/the-reference-case (accessed 20 September 2016).

\section{Patterson 2010}

Patterson BO, Hinchcliffe R, Loftus IM, Thompson MM, Holt PJE. DVT: a new era in anticoagulant therapy. Arteriosclerosis, Thrombosis, and Vascular Biology 2010;30:669-74.

\section{Schulman 2006}

Schulman S, Lindmarker P, Holmström M, Lärfars G, Carlsson A, Nicol $P$, et al. Post-thrombotic syndrome, recurrence, and death 10 years after the first episode of venous thromboembolism treated with warfarin for 6 weeks or 6 months. Journal of Thrombosis and Haemostasis 2006;4(4):734-42.

\section{Schultz 1995}

Schulz KF, Chalmers I, Hayes RJ, Altman DG. Empirical evidence of bias. Dimensions of methodological quality associated with estimates of treatment effects in controlled trials. JAMA 1995;273(5):408-12.

\section{Vedantham 2010}

Vedantham S. Catheter directed thrombolysis for deep vein thrombosis. Current Opinion Haematology 2010;17(5):464-8.

\section{White 2006}

White $\mathrm{RH}$. The epidemiology of venous thromboembolism. Circulation 2003;107(23):14-8.

\section{References to other published versions of this review Armon 2000}

Armon MP, Michaels JA. Thrombolysis for acute deep vein thrombosis. Cochrane Database of Systematic Reviews 2000, Issue 2. [DOI: 10.1002/14651858.CD002783]

\section{Watson 2004}

Watson L, Armon MP. Thrombolysis for acute deep vein thrombosis. Cochrane Database of Systematic Reviews 2004, Issue 3. [DOI: 10.1002/14651858.CD002783.pub2]

\section{Watson 2010}

Watson L, Armon MP. Thrombolysis for acute deep vein thrombosis. Cochrane Database of Systematic Reviews 2010, Issue 1. [DOI: 10.1002/14651858.CD002783.pub2]

\section{Watson 2014}

Watson L, Broderick C, Armon MP. Thrombolysis for acute deep vein thrombosis. Cochrane Database of Systematic Reviews 2014, Issue 1. [DOI: 10.1002/14651858.CD002783.pub3]

* Indicates the major publication for the study 
CHARACTERISTICS OF STUDIES

Characteristics of included studies [ordered by study ID]

Arneson 1978

\begin{tabular}{|c|c|}
\hline \multirow[t]{4}{*}{ Methods } & Allocation: random \\
\hline & Single blind \\
\hline & Exclusions after randomisation: 1 \\
\hline & Loss to follow-up: nil \\
\hline \multirow[t]{6}{*}{ Participants } & Country: Norway \\
\hline & Participants: 43 \\
\hline & Age: $<70$ years \\
\hline & Sex: Male and female \\
\hline & $\begin{array}{l}\text { Inclusion criteria: inpatients with venographically confirmed DVT extending proximally beyond the calf } \\
<5 \text { days duration }\end{array}$ \\
\hline & $\begin{array}{l}\text { Exclusion criteria: bleeding dysfunction; surgery within } 7 \text { days; GI/GU bleeding; stroke; diastolic BP > } \\
120 \text { mmHg; hypertensive retinopathy grade } 3 \text { - } 4 \text {; renal/hepatic insufficiency; pregnancy; malignancy; } \\
\text { age > } 70\end{array}$ \\
\hline
\end{tabular}

Interventions

Treatment: streptokinase 250,000 U loading IV, then 100,000 IU/hour IV 72 - 96 hours

Control: heparin 15,000 IU IV bolus, 30,000 IU infusion IV 72 - 90 hours

Co-treatment: hydrocortisone $100 \mathrm{mg}$ IV, then prednisolone $10 \mathrm{mg}$ three times daily during streptokinase infusion. Warfarin begun after streptokinase along with heparin until warfarin effective

In control group, warfarin begun after 72 - 90 hours with continuation of heparin until warfarin effective

21 days: mortality; PE; major bleeding; clot lysis
6 years: mortality; recurrent DVT; post-thrombotic syndrome; leg ulceration

Notes

40 randomised, 1 excluded as diagnosis of DVT in error

3 patients included who were not randomised, 2 streptokinase, 1 control

\section{Risk of bias}

\begin{tabular}{lll}
\hline Bias & Authors' judgement & Support for judgement \\
\hline $\begin{array}{l}\text { Random sequence genera- } \\
\text { tion (selection bias) }\end{array}$ & Low risk & "...performed by our statistician on the basis of random numbers" \\
\hline $\begin{array}{l}\text { Allocation concealment } \\
\text { (selection bias) }\end{array}$ & Low risk & $\begin{array}{l}\text { "...allocation to the treatment groups was performed by using sealed en- } \\
\text { velopes" }\end{array}$ \\
\hline $\begin{array}{l}\text { Blinding of participants } \\
\begin{array}{l}\text { and personnel (perfor- } \\
\text { mance bias) }\end{array}\end{array}$ & Low risk & $\begin{array}{l}\text { not possible due to intervention but judged low risk as outcome assessment } \\
\text { well described }\end{array}$ \\
\hline $\begin{array}{l}\text { Blinding of outcome as- } \\
\text { sessment (detection bias) }\end{array}$ & Low risk & "the radiologic evaluation was done without knowledge of the treatment giv- \\
\end{tabular}


Arneson 1978 (Continued)

All outcomes

Incomplete outcome data Low risk no missing data
(attrition bias)

(attrition bias)

All outcomes

Selective reporting (re- Low risk all outcomes reported
porting bias)

porting bias)

Other bias Low risk none

\section{Common 1976}

\begin{tabular}{|c|c|c|}
\hline \multirow[t]{4}{*}{ Methods } & \multicolumn{2}{|l|}{ Allocation: random } \\
\hline & \multicolumn{2}{|l|}{ Single blind } \\
\hline & \multicolumn{2}{|c|}{ Exclusions after randomisation: nil } \\
\hline & \multicolumn{2}{|c|}{ Losses to follow-up: 23 at 7 months } \\
\hline \multirow[t]{6}{*}{ Participants } & \multicolumn{2}{|l|}{ Country: USA } \\
\hline & \multicolumn{2}{|l|}{ Participants: 50} \\
\hline & \multicolumn{2}{|l|}{ Age: > 18 years } \\
\hline & \multicolumn{2}{|l|}{ Sex: Male and female } \\
\hline & \multicolumn{2}{|c|}{ Inclusion criteria: venographically confirmed DVT duration $<14$ days } \\
\hline & \multicolumn{2}{|c|}{$\begin{array}{l}\text { Exclusion criteria: pregnancy; surgery or childbirth }<10 \text { days; bleeding dysfunction; peptic ulcer; recent } \\
\text { streptococcal infection; active TB; carotid bruit; stroke }<6 \text { months; diastolic BP }>100 \text { mmHg; atrial fib- } \\
\text { rillation; hypertensive retinopathy grade } 3 / 4 \text {; hepatic/renal biopsy aortography }<14 \text { days }\end{array}$} \\
\hline \multirow[t]{3}{*}{ Interventions } & \multicolumn{2}{|c|}{$\begin{array}{l}\text { Treatment: hydrocortisone } 100 \mathrm{mg} \text { IV then streptokinase IV } 250,000 \mathrm{U} \text { over } 30 \text { minutes, then } 100,000 \mathrm{U} / \\
\text { hour titrated for } 72 \text { hours. Followed by IV heparin titrated over } 7 \text { days }\end{array}$} \\
\hline & \multicolumn{2}{|c|}{ Control: IV heparin $150 \mathrm{U} / \mathrm{kg}$ loading dose then titrated for 10 days } \\
\hline & \multicolumn{2}{|c|}{ Co-treatment: warfarin given from day $6-7$} \\
\hline \multirow[t]{2}{*}{ Outcomes } & \multicolumn{2}{|c|}{3 - 10 days: clot lysis; bleeding; stroke; mortality } \\
\hline & \multicolumn{2}{|l|}{7 months: clot lysis } \\
\hline Notes & \multicolumn{2}{|c|}{ Did not specify whether arm vein thrombosis included or not } \\
\hline \multicolumn{3}{|l|}{ Risk of bias } \\
\hline Bias & Authors' judgement & Support for judgement \\
\hline $\begin{array}{l}\text { Random sequence genera- } \\
\text { tion (selection bias) }\end{array}$ & Unclear risk & stated "randomized" but no further details given \\
\hline $\begin{array}{l}\text { Allocation concealment } \\
\text { (selection bias) }\end{array}$ & Unclear risk & not described \\
\hline
\end{tabular}




\section{Common 1976 (Continued)}

Blinding of participants Low risk not described but judged as low risk of bias as outcome assessment blinding and personnel (perfordescribed mance bias)

All outcomes

\begin{tabular}{|c|c|c|}
\hline $\begin{array}{l}\text { Blinding of outcome as- } \\
\text { sessment (detection bias) } \\
\text { All outcomes }\end{array}$ & Low risk & $\begin{array}{l}\text { "..two radiologists who were unaware of the patient's treatment were evaluat- } \\
\text { ed the venograms..." }\end{array}$ \\
\hline
\end{tabular}

Incomplete outcome data Low risk (attrition bias)

no missing data

All outcomes

\begin{tabular}{lll}
\hline $\begin{array}{l}\text { Selective reporting (re- } \\
\text { porting bias) }\end{array}$ & Low risk & all outcomes reported \\
\hline Other bias & Low risk & none \\
\hline
\end{tabular}

Elliot 1979

\begin{tabular}{ll}
\hline Methods & $\begin{array}{l}\text { A prospective, controlled, randomised, comparative study to compare conventional full dose heparin } \\
\text { and streptokinase (Kabikinase) }\end{array}$
\end{tabular}

Participants

Country: South Africa
Total randomised: 51 (strep 26, hep 25)

Sex: Male (17) and female (34)

Mean age hep group: 51 years; strep group: 48 years

Inclusion criteria: proximal vein thrombosis diagnosed by bilateral ascending phlebograph and less than 8 days clinical history of DVT

Exclusion criteria: any surgery within 7 days or neurosurgical within 2 months, pregnancy, menstruation, haemorrhagic diatheses, diastolic blood pressure of $110 \mathrm{mmHg}$, suspected or know bleeding lesions, cerebrovascular accident within 6 months, recent streptococcal infection, previous streptokinase therapy within 6 months, liver or renal disease

2 patients in strep group had axillary vein thrombosis

Interventions

Treatment: $100 \mathrm{mg}$ of hydrocortisone 15 mins prior to first streptokinase dose and repeated 6 hourly for duration of strep treatment. Strepokinase (Kabikinase) loading dose of 600,000 $\mathrm{U}$ given by infusion over a period of 30 mins. Then 100,000 U hourly for 3 days by infusion pump. Then heparin for 4 days dose adjusted to maintain Lee-White clotting time to at least 2.5 - 3 normal

Control: At diagnosis 10,000 U of heparin given by iv injection. The 10,000 U iv 6 hourly using constant infusion pump. Dose adjusted to maintain Lee-White clotting time to at least 2.5 - 3 normal

Treatment continued for 7 days

$30 \mathrm{mg}$ warfarin given as a loading dose to both groups 36 hours before heparin therapy terminated, warfarin continued for 8 weeks, dose adjusted to maintain pro-thrombin index 40 - 60 per cent

All participants bed rest for duration, foot of bed raised by $60 \mathrm{~cm}$, elastic support provided 
Elliot 1979 (Continued)

Notes

\section{Risk of bias}

\begin{tabular}{|c|c|c|}
\hline Bias & Authors' judgement & Support for judgement \\
\hline $\begin{array}{l}\text { Random sequence genera- } \\
\text { tion (selection bias) }\end{array}$ & Unclear risk & no details given \\
\hline $\begin{array}{l}\text { Allocation concealment } \\
\text { (selection bias) }\end{array}$ & Unclear risk & no details given \\
\hline $\begin{array}{l}\text { Blinding of participants } \\
\text { and personnel (perfor- } \\
\text { mance bias) } \\
\text { All outcomes }\end{array}$ & Low risk & no details given but judged low risk as outcome assessment well described \\
\hline $\begin{array}{l}\text { Blinding of outcome as- } \\
\text { sessment (detection bias) } \\
\text { All outcomes }\end{array}$ & Low risk & "..all radiographs were assessed on a blind basis" \\
\hline $\begin{array}{l}\text { Incomplete outcome data } \\
\text { (attrition bias) } \\
\text { All outcomes }\end{array}$ & Low risk & no missing data \\
\hline $\begin{array}{l}\text { Selective reporting (re- } \\
\text { porting bias) }\end{array}$ & Low risk & all outcomes reported \\
\hline Other bias & Low risk & none \\
\hline
\end{tabular}

\section{Elsharawy 2002}

\begin{tabular}{ll}
\hline Methods & Allocation: random \\
Single blind & Exclusions after randomisation - nil \\
& Losses to follow-up - nil \\
\hline Country: Egypt & Participants: 35 \\
Age: $<70$ years & Sex: Male and female \\
Inclusion criteria: iliofemoral venous thrombosis confirmed by duplex or venography duration $<10$ \\
days; life expectancy $>6$ months \\
Exclusion criteria: surgery $<14$ days; previous CVA/CNS disease; GI bleed $<1$ year; BP $>180 / 100 ;$ preg- \\
nancy etc.; other contraindications to thrombolysis not explicitly described
\end{tabular}


Elsharawy 2002 (Continued)

Control: heparin IV bolus $5000 \mathrm{U}$, then adjusted continuous infusion. Warfarin begun the same evening

Co treatment: none described

\begin{tabular}{ll}
\hline Outcomes & 1 week: clot lysis; bleeding; mortality; PE \\
& 6 months: clot lysis; venous function \\
\hline Notes & Catheter-directed thrombolysis, as distinct from systemic or loco-regional
\end{tabular}

\section{Risk of bias}

\begin{tabular}{|c|c|c|}
\hline Bias & Authors' judgement & Support for judgement \\
\hline $\begin{array}{l}\text { Random sequence genera- } \\
\text { tion (selection bias) }\end{array}$ & Low risk & "...computer designated cards assigning patients to either groups" \\
\hline $\begin{array}{l}\text { Allocation concealment } \\
\text { (selection bias) }\end{array}$ & Unclear risk & not mentioned \\
\hline $\begin{array}{l}\text { Blinding of participants } \\
\text { and personnel (perfor- } \\
\text { mance bias) } \\
\text { All outcomes }\end{array}$ & Low risk & $\begin{array}{l}\text { not possible due to intervention but judged low risk as outcome assessment } \\
\text { well described }\end{array}$ \\
\hline $\begin{array}{l}\text { Blinding of outcome as- } \\
\text { sessment (detection bias) } \\
\text { All outcomes }\end{array}$ & Low risk & $\begin{array}{l}\text { "..panel unaware of the sequencing of the studies or if images were obtained } \\
\text { at baseline, } 24 \text { - } 48 \text { hours after randomisation or before discharge" }\end{array}$ \\
\hline $\begin{array}{l}\text { Incomplete outcome data } \\
\text { (attrition bias) } \\
\text { All outcomes }\end{array}$ & Low risk & complete data available \\
\hline $\begin{array}{l}\text { Selective reporting (re- } \\
\text { porting bias) }\end{array}$ & Low risk & pre-specified outcomes reported \\
\hline Other bias & Low risk & none \\
\hline
\end{tabular}

Enden 2011

Methods Multicentre, open label, randomised controlled trial of the efficacy and safety of additional catheter-directed thrombolysis (CDT) with alteplase

Three years duration (January 2006 to January 2009)

Ethical approval obtained

Participants Country: Recruited from 20 centres, 8 hospital trusts in Norway

Total randomised: 189

Age: 18 to 75 years

Sex: Male and female

Inclusion criteria: objectively verified (diagnostic imaging) first time DVT in the upper thigh, common iliac vein, or combined iliofemoral segment, symptom duration up to 21 days 
Exclusion criteria: Anticoagulant treatment before trial entry ( $>7$ days previous), contraindications to thrombolytic treatment, indications for thrombolytic treatment, severe anaemia, thrombocytopenia, severe renal failure, sever hypertension, pregnancy or thrombosis within 7 days postpartum, less than 14 days postsurgery or post-trauma, history of subarachnoid or intracerebral bleeding, disease with life expectancy less than 24 months, drug misuse or mental disease that could interfere with treatment and follow-up, former ipsilateral proximal DVT, malignant disease needing chemotherapy, any thrombolytic treatment within 7 days before trial inclusion

Anticoagulation with subcutaneous LMWH (dalteparin or enoxaparin) for at least 5 days, discontinued for at least 8 hours before CDTreintroduced with warfarin 1 hour after procedure. Infusion catheter covering thrombosed segments introduced under ultrasound. $20 \mathrm{mg}$ alteplase diluted $500 \mathrm{~mL} 0.9 \% \mathrm{NaCl}$ given at $0.01 \mathrm{mg} / \mathrm{kg}$ per hr for a maximum $96 \mathrm{hrs}$. Maximum dose $20 \mathrm{mg} / 24 \mathrm{hrs}$. Unfractionated heparin given simultaneously as a continuous iv infusion, dose adjusted to keep activated partial thromboplastin time at 1.2 to 1.7 times higher than the upper normal limit. No additional antiplatelet treatment given. Use of adjunctive angioplasty and stents to establish flow and obtain less than $50 \%$ residual stenosis left to the discretion of the operator. Advised to wear knee high elastic compression stockings (class II) daily for 24 months

Control (number randomised 99)

Anticoagulation with subcutaneous LMWH (dalteparin or enoxaparin) and warfarin for at least 5 days, followed by warfarin alone to target intensity INR 2 to 3 . Advised to wear knee high elastic compression stockings (class II) daily for 24 months

Outcomes

PTS at 6 and 24 months, and 5 years measured using Villalta score and classified as PTS if score 5 or over, or if venous ulcer present

Iliofemoral patency, graded daily during thrombolysis, 6 months and 24 months and 5 years

Bleeding complications defined as major if clinically overt, or haemoglobin decrease of $2 \mathrm{~g}$ per decilitre or more, transfusion of 2 or more units of red cells or whole blood, retroperitoneal or intracranial, occurred in a critical organ or contributed to death

Clinically relevant/non-major bleeding: epistaxis requiring intervention, large visible haematoma on skin, spontaneous macroscopic haematuria

Venous function: at 6 months and 24 months, doppler ultrasound using pneumatic cuff with patient standing, standardised compression unit, venous incompetence with reflux valve closure time $>0.5$ seconds

Functionally significant venous obstruction was indicated by a decline in the plethysmographic curve measured by APG (Macrola, Norway). Iliofemoral patency was defined as regained when flow in the pelvic and femoral vein and complete compressibility of the femoral vein was assessed by ultrasound; and no functional venous obstruction was indicated by APG

Recurrent VTE; verified with routine imaging at local trial site

Mortality at 24 months and 5 years

Health related quality of life: EQ-5D measuring mobility, self care, activity, pain and anxiety at 6 month, 24 months and 5 years

VEINES QoL/Sym specific to lower limb problems, measures symptoms, limitation, psychological impact over 4 weeks and change over a year, carried out at 6 months, 24 months and 5 years. VEINES-QOL assesses QoL and VEINES-Sym measures symptom severity only

Cost effectiveness: Markov model, examining PTS, bleeding from CDT and post DVT states, costs in US $\$$, third party payer and lifetime horizon. One way and probabilistic sensitivity analysis in hypothetical cohort age 50. Discounted costs and utilities 3\% annually. Long term cumulative incidence after 8 years $30 \%$ PTS, $88 \%$ severe PTS. QALY, costs, incremental cost-effectiveness ratio 
Enden 2011 (Continued)

Risk of bias

\begin{tabular}{|c|c|c|}
\hline Bias & Authors' judgement & Support for judgement \\
\hline $\begin{array}{l}\text { Random sequence genera- } \\
\text { tion (selection bias) }\end{array}$ & Low risk & $\begin{array}{l}\text { "...multi-centre, open label, randomised controlled trial..". Random sequence } \\
\text { generated with the website www.randomization.com }\end{array}$ \\
\hline $\begin{array}{l}\text { Allocation concealment } \\
\text { (selection bias) }\end{array}$ & Low risk & "...sealed opaque, numbered envelopes" \\
\hline $\begin{array}{l}\text { Blinding of participants } \\
\text { and personnel (perfor- } \\
\text { mance bias) } \\
\text { All outcomes }\end{array}$ & Low risk & $\begin{array}{l}\text { blinding of participants not possible due to the nature of the interventions, } \\
\text { judged not to effect outcome as these very well defined }\end{array}$ \\
\hline $\begin{array}{l}\text { Blinding of outcome as- } \\
\text { sessment (detection bias) } \\
\text { All outcomes }\end{array}$ & Low risk & assessors had "no knowledge of patient history or treatment" \\
\hline $\begin{array}{l}\text { Incomplete outcome data } \\
\text { (attrition bias) } \\
\text { All outcomes }\end{array}$ & Low risk & $\begin{array}{l}\text { well described. "Missing outcome data because of withdrawal of consent or } \\
\text { death from cancer or other causes not related to CDT or anticoagulation were } \\
\text { assumed to be missing independently of treatment and not included in the } \\
\text { analyses" }\end{array}$ \\
\hline $\begin{array}{l}\text { Selective reporting (re- } \\
\text { porting bias) }\end{array}$ & Low risk & all outcomes reported \\
\hline Other bias & Low risk & $\begin{array}{l}\text { other bias unlikely although we note that compliance with compression stock- } \\
\text { ings is slightly higher in intervention group: } 63 \% \text { versus } 52 \%\end{array}$ \\
\hline
\end{tabular}

Goldhaber 1990

$\begin{array}{ll}\text { Methods } & \text { Allocation: random } \\ \text { Single blind } \\ \text { Exclusions after randomisation: nil } \\ \text { Losses to follow-up: nil }\end{array}$

Participants
Participants: 64 patients, 65 randomisations
Age: 18 to 75 years
Sex: Male and female
Inclusion criteria: venographically documented DVT, in popliteal or more proximal veins < 14 days dura-
tion
Exclusion criteria: major bleeding; bleeding dysfunction; stroke; head trauma $<3$ months; GI/GU bleed
$<4$ weeks; trauma/surgery < 14 days; renal/hepatic dysfunction; therapeutic warfarin; lactation/preg-
nancy; low platelet count; contraindication to contrast agent
Treatment $(2$ groups):
tPA alone $0.05 \mathrm{mg} / \mathrm{kg} /$ hour IV over 24 hours, then heparin $100 \mathrm{U} / \mathrm{kg}$ bolus, then $1000 \mathrm{U} / \mathrm{hour}$, adjusted


Goldhaber 1990 (Continued)

tPA as above plus heparin concomitantly as above

Control: heparin alone $100 \mathrm{U} / \mathrm{kg}$ bolus, then $1000 \mathrm{U} /$ hour

Co-treatment: warfarin begun in all groups on second day

Heparin adjusted in all groups

\begin{tabular}{ll}
\hline Outcomes & 36 hours: clot lysis; bleeding \\
\hline Notes & 2 patients were not treated according to randomisation, one receiving tPA, one receiving heparin \\
& $\begin{array}{l}5 \text { of } 65 \text { venograms not analysed. } 1 \text { patient with recurrent DVT was re-entered - } 64 \text { patients } 65 \text { randomi- } \\
\text { sations }\end{array}$ \\
\hline
\end{tabular}

\section{Risk of bias}

\section{Bias Authors' judgement Support for judgement}

Random sequence genera- Low risk
tion (selection bias)

"randomly assigned to (groups) by opening the appropriate consecutively numbered sealed envelope according to a 2:2:1 allocation scheme. Seperate treatment assignments were generated block random number sequences"

\begin{tabular}{|c|c|c|}
\hline $\begin{array}{l}\text { Allocation concealment } \\
\text { (selection bias) }\end{array}$ & Unclear risk & open label trial \\
\hline $\begin{array}{l}\text { Blinding of participants } \\
\text { and personnel (perfor- } \\
\text { mance bias) } \\
\text { All outcomes }\end{array}$ & Low risk & $\begin{array}{l}\text { "both patients and investigators knew which drug regimen was being utilized" } \\
\text { but judged low risk as outcome assessment well described }\end{array}$ \\
\hline $\begin{array}{l}\text { Blinding of outcome as- } \\
\text { sessment (detection bias) } \\
\text { All outcomes }\end{array}$ & Low risk & $\begin{array}{l}\text { "images compared and assessed by a vascular imaging panel that was blinded } \\
\text { to randomization assignment and unaware of whether images were obtained } \\
\text { at baseline, } 24 \text { to } 48 \text { hours after randomization or before discharge" }\end{array}$ \\
\hline $\begin{array}{l}\text { Incomplete outcome data } \\
\text { (attrition bias) } \\
\text { All outcomes }\end{array}$ & Low risk & all accounted for \\
\hline $\begin{array}{l}\text { Selective reporting (re- } \\
\text { porting bias) }\end{array}$ & Low risk & all outcomes reported \\
\hline Other bias & Low risk & none \\
\hline
\end{tabular}

Goldhaber 1996

$\begin{array}{ll}\text { Methods } & \text { Randomised controlled trial to assess efficacy and safety of rUK compared to heparin alone } \\ \text { September } 1992 \text { to April } 1994 \\ 361 \text { screened, total randomised: } 17 \\ \text { Allocation on } 1: 1 \text { basis on morning of treatment } \\ \text { Open labelled study } \\ \text { Written informed consent } \\ \text { Participants }\end{array}$


Goldhaber 1996 (Continued)

Participants: 17

Symptoms of DVT $<14$ days

Age: > 18 years

\section{Sex: Male and female}

Inclusion criteria: DVT diagnosed by ultrasonography or venography for proximal lower extremity (popliteal,femoral, iliac veins with or without calf vein thrombosis) or MRI for upper extremity (brachial, axillary, subclavian, internal jugular veins)

Exclusion criteria: stroke, intracranial disease or trauma, major chronic bleeding, major GI bleeding within one year, major urological bleeding 1 month, trauma or major surgery at non-compressible site within 14 days, hypertension $>180 / 110 \mathrm{~mm} \mathrm{Hg}$, haematocrit $<25 \%$ or platelet count $<100,000 / \mathrm{mm}^{3}$, pregnancy, nursing mothers, occult blood in stool, gross haematuria

Interventions

Recombinant urokinase group: 3 bolus infusions of $250,000 \mathrm{U}$ in 5 mins via peripheral vein followed by continuous infusion of 750,000 U over 25 mins and 8 hours after initial dose. Final dose 24 hours after initial dose. Heparin administered 12 hours after first rUK dose for 12 hours until final rUK dose. Three hours after final rUK hep resumed to maintain activated PPT time of 60 to 80 seconds. Warfarin started the same evening to maintain INR of 2 to 3

Heparin group: initial bolus of 5000 to $10,000 \mathrm{U}$ if they were not already receiving IV hep, then continuous infusion adjusted to maintain activated PPT time of 60 to 80 seconds. First dose of warfarin given within 24 hours of randomisation, target INR was 2 to 3

\begin{tabular}{ll}
\hline Outcomes & Clot lysis, venous flow, blood count and bleeding complications, fibrinogen levels \\
\hline Notes & 1 patient in each group had upper extremity DVT \\
& UK group had longer duration of symptoms (6 days versus 3 days)
\end{tabular}

\section{Risk of bias}

\begin{tabular}{|c|c|c|}
\hline Bias & Authors' judgement & Support for judgement \\
\hline $\begin{array}{l}\text { Random sequence genera- } \\
\text { tion (selection bias) }\end{array}$ & Unclear risk & randomisation method not described \\
\hline $\begin{array}{l}\text { Allocation concealment } \\
\text { (selection bias) }\end{array}$ & Unclear risk & open label \\
\hline $\begin{array}{l}\text { Blinding of participants } \\
\text { and personnel (perfor- } \\
\text { mance bias) } \\
\text { All outcomes }\end{array}$ & Low risk & no details given but judged low risk as outcome assessment well described \\
\hline $\begin{array}{l}\text { Blinding of outcome as- } \\
\text { sessment (detection bias) } \\
\text { All outcomes }\end{array}$ & Low risk & $\begin{array}{l}\text { "...images compared and assessed by vascular panel blinded to randomisation } \\
\text { assignment and time point of image" }\end{array}$ \\
\hline $\begin{array}{l}\text { Incomplete outcome data } \\
\text { (attrition bias) } \\
\text { All outcomes }\end{array}$ & Low risk & all data reported \\
\hline $\begin{array}{l}\text { Selective reporting (re- } \\
\text { porting bias) }\end{array}$ & Low risk & all outcomes reported \\
\hline Other bias & Low risk & none \\
\hline
\end{tabular}




$\begin{array}{ll}\text { Methods } & \text { Allocation: random } \\ \text { Single blind } & \text { Exclusions after randomisation: } 2 \\ \text { Losses to follow-up: nil }\end{array}$

\begin{tabular}{ll}
\hline Outcomes & 1 month: mortality; PE; clot lysis; bleeding \\
& 6 to 12 months: clot lysis after partial lysis \\
\hline Notes & 1 excluded as died of PE in heparin group. 1 excluded due to bleeding in streptokinase group \\
& Included 7 patients with tibial vein thrombosis only (4 heparin, 2 streptokinase, 1 Arwin) \\
\hline
\end{tabular}

\section{Risk of bias}

\begin{tabular}{lll}
\hline Bias & Authors' judgement & Support for judgement \\
\hline $\begin{array}{l}\text { Random sequence genera- } \\
\text { tion (selection bias) }\end{array}$ & Unclear risk & description not clear \\
\hline $\begin{array}{l}\text { Allocation concealment } \\
\text { (selection bias) }\end{array}$ & Unclear risk & description not clear \\
\hline $\begin{array}{l}\text { Blinding of participants } \\
\text { and personnel (perfor- } \\
\text { mance bias) }\end{array}$ & High risk \\
$\begin{array}{ll}\text { All outcomes } \\
\text { Blinding of outcome as- } \\
\text { sessment (detection bias) } \\
\text { All outcomes }\end{array}$ & High risk & not described \\
\hline $\begin{array}{l}\text { Incomplete outcome data } \\
\text { (attrition bias) } \\
\begin{array}{l}\text { All outcomes } \\
\hline\end{array}\end{array}$ & Low risk & not described \\
\hline
\end{tabular}


Kakkar 1969 (Continued)

Selective reporting (re- Low risk all outcomes reported
porting bias)

Other bias Low risk none

Kiil 1981

\begin{tabular}{ll}
\hline Methods & Allocation: random \\
& Double blind \\
& Exclusions after randomisation: 1 \\
& Losses to follow-up: nil
\end{tabular}

Participants
Participants: 20
Age: 17 to 79 years
Sex: Male and female
Inclusion criteria: venographically confirmed DVT duration $<72$ hours
Exclusion criteria: not described

\begin{tabular}{ll}
\hline Interventions & $\begin{array}{l}\text { Treatment: urokinase 200,000 U IV over 24 hours. After } 18 \text { hours, heparin loading dose of 15,000 units } \\
\text { then 40,000 U/day for } 5 \text { days }\end{array}$ \\
Control: heparin 40,000 U/day IV for 6 days \\
Co-treatment: not described \\
\hline Outcomes & $\begin{array}{l}6 \text { days: clot lysis; bleeding } \\
2 \text { weeks: mortality }\end{array}$ \\
\hline Notes & $\begin{array}{l}1 \text { excluded from heparin group due to bleeding. Low dose urokinase. Did not specify whether calf vein } \\
\text { thrombosis was included }\end{array}$ \\
\hline
\end{tabular}

\section{Risk of bias}

\begin{tabular}{lll}
\hline Bias & Authors' judgement & Support for judgement \\
\hline $\begin{array}{l}\text { Random sequence genera- } \\
\text { tion (selection bias) }\end{array}$ & Unclear risk & "randomly separated" but no further details given \\
\hline $\begin{array}{l}\text { Allocation concealment } \\
\text { (selection bias) }\end{array}$ & Unclear risk & $\begin{array}{l}\text { "allocation of the patients ... was performed by one of the participants" no fur- } \\
\text { ther details given }\end{array}$ \\
\hline $\begin{array}{l}\text { Blinding of participants } \\
\text { and personnel (perfor- } \\
\text { mance bias) }\end{array}$ & Low risk & "mixture of liquids to be infused was performed by one of the participants" \\
$\begin{array}{l}\text { All outcomes } \\
\begin{array}{l}\text { Blinding of outcome as- } \\
\text { sessment (detection bias) }\end{array}\end{array}$ & Low risk & $\begin{array}{l}\text { "clinical evaluation and interpretation of phlebograms were preformed in a } \\
\text { double-blind fashion" }\end{array}$ \\
\hline
\end{tabular}


Kiil 1981 (Continued)

All outcomes

\begin{tabular}{lll}
$\begin{array}{l}\text { Incomplete outcome data } \\
\text { (attrition bias) } \\
\text { All outcomes }\end{array}$ & Low risk & exclusions explained \\
\hline $\begin{array}{l}\text { Selective reporting (re- } \\
\text { porting bias) }\end{array}$ & Low risk & all outcomes reported \\
\hline Other bias & Low risk & none
\end{tabular}

\section{Marder 1977}

Methods $\quad$ Randomised controlled trial, single blind, "..to provide evidence that lytic agents are more effective than heparin in dissolving venous thrombi"

Declaration of Helsinki, written and verbal explanation of procedures and risks of study, written and informed consent

Country: USA
Participants: 24 randomised; 12 heparin and 12 strep (plus 3 non-randomised)
Age over 18 years mean age in hep 50.2 and strep 54.7 years
Male and females with venographically proved peripheral DVT
Mean symptom duration in heparin group was 6.2 days and 8.5 days for the strep group
Patients were included in study if 'no evidence of hemorrhagic tendency, active gastrointestinal or gen-
itourinary bleeding, severe system hypertension, atrial fibrillation, pregnancy, 10 days post partum,
surgery, hepatic or renal biopsy, translumbar aortography. Four patients in strep group had tumours,
three had obstructed venous return in veins which contained thrombus. Two patients (one each he-
parin and strep), had thrombosis of upper extremity

Interventions All patients iv bolus injection of $100 \mathrm{mg}$ hydrocortisone prior to start of strep or hep

Treatment: strep was administered as a priming dose of $250,000 \mathrm{U}$ in 20 minute, followed by a maintenance infusion of $100,000 \mathrm{U} /$ hour for 72 hours

Control: heparin was administered as an initial iv dose of $150 \mathrm{U} / \mathrm{kg}$ of body weight over 5 minutes followed by a 72 hour infusion at a rate which prolonged the PTT to 60 to 100 seconds

After 72 hours of treatment both groups received continuous or intermittent iv heparin according to guidelines. A maintenance dose of warfarin (coumadin) was administered on day seven and heparin was discontinued when the prothrombin time was prolonged to 1.5 to 2.5 times the control value. Warfarin was continued for three months or longer at physicians discretion

Outcomes Venography (pre-treatment and five days post treatment), haemostasis, complications

Notes

Three patients were added in a non-randomised fashion to the streptokinase group. Mean age 56 years and symptom duration 8.7 days. These patients were added as three patients from the randomised group did not have follow-up venograms

\section{Risk of bias}

\begin{tabular}{lll}
\hline Bias & Authors' judgement & Support for judgement \\
\hline $\begin{array}{l}\text { Random sequence genera- } \\
\text { tion (selection bias) }\end{array}$ & Unclear risk & $\begin{array}{l}\text { "..after entry patients were randomly allocated to either the heparin or the } \\
\text { streptokinase group..." but it is not clear by which method this was done }\end{array}$ \\
\hline \hline
\end{tabular}


Marder 1977 (Continued)

Allocation concealment Unclear risk no information given
(selection bias)

\begin{tabular}{|c|c|c|}
\hline $\begin{array}{l}\text { Blinding of participants } \\
\text { and personnel (perfor- } \\
\text { mance bias) } \\
\text { All outcomes }\end{array}$ & Low risk & $\begin{array}{l}\text { no attempt to blind described but this judged low risk to be consistent with } \\
\text { risk of bias assessing of other studies }\end{array}$ \\
\hline $\begin{array}{l}\text { Blinding of outcome as- } \\
\text { sessment (detection bias) } \\
\text { All outcomes }\end{array}$ & Unclear risk & $\begin{array}{l}\text { for assessment of venography "films were interpreted independently (by two } \\
\text { authors)...without knowing the drug administered or whether the study was } \\
\text { before or after treatment". For bleeding no clear definition for grading or as- } \\
\text { sessment are given }\end{array}$ \\
\hline
\end{tabular}

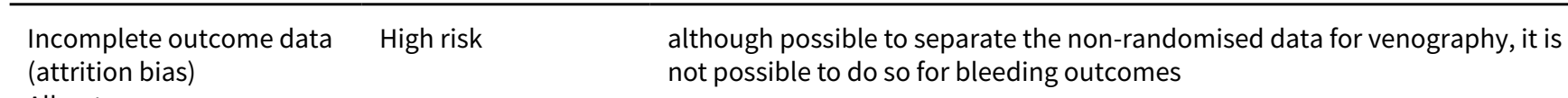

All outcomes not possible to do so for bleeding outcomes

\begin{tabular}{lll}
\hline $\begin{array}{l}\text { Selective reporting (re- } \\
\text { porting bias) }\end{array}$ & High risk & $\begin{array}{l}\text { not possible to determine which results from randomised patients for all out- } \\
\text { comes }\end{array}$ \\
\hline Other bias & High risk & three non-randomised patients added to study post-randomisation \\
\hline
\end{tabular}

Schulman 1986

\begin{tabular}{ll}
\hline Methods & Allocation: random \\
& Single blind \\
& Exclusions after randomisation: 2 \\
& Losses to follow-up: nil
\end{tabular}

Country: Sweden
Participants: 38
Age: 26 to 74 years
Sex: Male and female
Inclusion criteria: venographically confirmed calf vein thrombosis
duration < 7 days
Exclusion criteria: previous thrombosis same leg; contraindication to thrombolysis

Interventions Treatment: streptokinase 50,000 IU IV over 15 minutes then 100,000 IU over 12 hours for up to 7 days, titrated. Given with 5000 IU heparin IV over 12 hours. Warfarin begun after streptokinase ended

Control: heparin 5000 IU IV bolus then 30,000 IU per day, titrated for 7 days. Warfarin begun simultaneously

Co-treatment: paracetamol, hydrocortisone or moduretic if necessary. 24 hours bed rest. Warfarin given for 5 to 6 months. Leg elevation. Elastic bandages. Elastic stockings where swelling or venous insufficiency detected at discharge or follow-up

$\begin{array}{ll}\text { Outcomes } & 1 \text { week: bleeding; clot lysis (venographic score); mortality; stroke; PE } \\ & 1 \text { month: clot lysis }\end{array}$


Schulman 1986 (Continued)

\section{1 year: clot lysis}

Up to 5 years: post-thrombotic syndrome; foot volumetry

Notes Low dose streptokinase. 2 patients excluded after randomisation, as they had previous thromboses

\section{Risk of bias}

\begin{tabular}{|c|c|c|}
\hline Bias & Authors' judgement & Support for judgement \\
\hline $\begin{array}{l}\text { Random sequence genera- } \\
\text { tion (selection bias) }\end{array}$ & Unclear risk & "randomised, prospective study" but no further details given \\
\hline $\begin{array}{l}\text { Allocation concealment } \\
\text { (selection bias) }\end{array}$ & Low risk & "allocated using sealed envelopes" \\
\hline $\begin{array}{l}\text { Blinding of participants } \\
\text { and personnel (perfor- } \\
\text { mance bias) } \\
\text { All outcomes }\end{array}$ & Low risk & $\begin{array}{l}\text { not possible due to the nature of the interventions but judged low risk as out- } \\
\text { come assessment well described }\end{array}$ \\
\hline $\begin{array}{l}\text { Blinding of outcome as- } \\
\text { sessment (detection bias) } \\
\text { All outcomes }\end{array}$ & Low risk & $\begin{array}{l}\text { "..venograms were evaluated blindly in retrospect by one and the same radiol- } \\
\text { ogist" }\end{array}$ \\
\hline $\begin{array}{l}\text { Incomplete outcome data } \\
\text { (attrition bias) } \\
\text { All outcomes }\end{array}$ & Low risk & no missing data \\
\hline $\begin{array}{l}\text { Selective reporting (re- } \\
\text { porting bias) }\end{array}$ & Low risk & all outcomes reported \\
\hline Other bias & Low risk & none \\
\hline
\end{tabular}

\section{Schweizer 1998}

\begin{tabular}{ll}
\hline Methods & Allocation: random \\
& Single blind \\
& Exclusions after randomisation: 2 \\
& Losses to follow-up: 1 \\
\hline
\end{tabular}

\section{Participants}

\section{Country: Germany}

Participants: 69

Age: 22 to 58 years

Sex: Male and female

Inclusion criteria: venographically confirmed DVT of leg duration $<7$ days

Exclusion criteria: PE; calf vein thrombosis; recurrent DVT; GI/GU bleed; inflammatory bowel disease; acute pancreatitis; surgery within 4 weeks; IM injection within 10 days; hypertensive retinopathy grade 3 or 4; intracerebral disease; cerebral surgery or trauma within 3 months; malignancy not in remission; 
Schweizer 1998 (Continued)

diabetic retinopathy stage 3 or 4; renal or hepatic failure; bleeding dysfunction; pregnancy, lactation, delivery within 20 days

\begin{tabular}{ll}
\hline Interventions & Treatment: (2 groups) tPA 20 mg IV into pedal vein over 4 hours each day for 7 days. Heparin IV given \\
concomitantly, with adjustment \\
Urokinase 100,000 IU/hr IV into pedal vein continuously for 7 days. Heparin IV for 7 days. Plasminogen \\
monitored Warfarin from day 7 to 12 months \\
Control: heparin IV, adjusted for 7 days \\
Co-treatment: bed rest and compression treatment. Warfarin from day 7 - 12 months in treatment \\
groups. Warfarin begun immediately, for 12 months in control group. Compression for 12 months for all \\
patients \\
$\begin{array}{l}7 \text { days: bleeding; clot lysis (no results for control group) } \\
\text { Outcomes }\end{array}$ \\
$\begin{array}{l}\text { Loco-regional thrombolysis. } 2 \text { patients excluded due to bleeding, } 1 \text { tPA, } 1 \text { urokinase. } 1 \text { lost to follow-up } \\
\text { from control group }\end{array}$ \\
\hline Notes
\end{tabular}

\section{Risk of bias}

\section{Bias}

Random sequence genera- Low risk tion (selection bias)

\begin{tabular}{lll}
\hline $\begin{array}{l}\text { Allocation concealment } \\
\text { (selection bias) }\end{array}$ & Unclear risk details \\
\hline
\end{tabular}

\begin{tabular}{|c|c|c|}
\hline $\begin{array}{l}\text { Blinding of participants } \\
\text { and personnel (perfor- } \\
\text { mance bias) } \\
\text { All outcomes }\end{array}$ & Low risk & $\begin{array}{l}\text { not described but judged unlikely to influence outcome assessment as well de- } \\
\text { scribed }\end{array}$ \\
\hline $\begin{array}{l}\text { Blinding of outcome as- } \\
\text { sessment (detection bias) } \\
\text { All outcomes }\end{array}$ & Low risk & $\begin{array}{l}\text { "...evaluated by an independent radiologist who was unaware of the treat- } \\
\text { ment the patients had received" }\end{array}$ \\
\hline $\begin{array}{l}\text { Incomplete outcome data } \\
\text { (attrition bias) } \\
\text { All outcomes }\end{array}$ & Low risk & no missing data \\
\hline $\begin{array}{l}\text { Selective reporting (re- } \\
\text { porting bias) }\end{array}$ & Low risk & all outcomes reported \\
\hline Other bias & Low risk & none \\
\hline
\end{tabular}

Schweizer 2000

\begin{tabular}{ll}
\hline Methods & Allocation: random \\
& Single blind \\
Exclusions after randomisation: nil
\end{tabular}


Schweizer 2000 (Continued)

Losses to follow-up: 12

Country: Germany
Participants: 250
Age: mean 40 years
Sex: Male and female
Inclusion criteria: thrombosis of popliteal or more proximal veins confirmed by venogram at more than
one level duration < 9 days
Exclusion criteria: no PE; recurrent DVT; calf vein thrombosis only; GI/GU bleeding; inflammatory bowel
disease < 12 months; acute pancreatitis; surgery or head trauma < 3 months; IM injection < 10 days; hy-
pertension; diabetic retinopathy stage 3 - 4; malignancy; renal or hepatic failure; bleeding dysfunction;
pregnancy, lactation, delivery within 20 days

Interventions

Treatment: (4 groups) local tPA $20 \mathrm{mg} /$ day, over 4 hours via pedal vein for 4 to 7 days. IV heparin given simultaneously at $1000 \mathrm{IU} /$ hour, adjusted

Local urokinase 100,000 IU/day infused continuously. Fibrinogen and plasminogen monitored. Heparin IV given concomitantly

Systemic streptokinase 3,000,000 U/day over 6 hours in conjunction with heparin for up to 7 days. Premedication: hydrocortisone $100 \mathrm{mg}$, ranitidine $50 \mathrm{mg}$, clemastine $2 \mathrm{mg}$

Systemic urokinase 5,000,000 IU/day over 4 hours for up to 7 days. IV heparin given concomitantly

Control: heparin IV, adjusted

Co-treatment: bedrest, compression bandages, warfarin and compression treatment continued for 12 months

\begin{tabular}{|c|c|c|}
\hline \multirow[t]{2}{*}{ Outcomes } & \multicolumn{2}{|c|}{7 days: PE; major bleeding; mortality; clot lysis } \\
\hline & \multicolumn{2}{|l|}{1 year: clot lysis } \\
\hline Notes & \multicolumn{2}{|c|}{4 losses to follow-up in systemic urokinase, systemic streptokinase and control groups } \\
\hline \multicolumn{3}{|l|}{ Risk of bias } \\
\hline Bias & Authors' judgement & Support for judgement \\
\hline $\begin{array}{l}\text { Random sequence genera- } \\
\text { tion (selection bias) }\end{array}$ & Unclear risk & "patients were randomly assigned" no further details given \\
\hline $\begin{array}{l}\text { Allocation concealment } \\
\text { (selection bias) }\end{array}$ & Unclear risk & no details given \\
\hline $\begin{array}{l}\text { Blinding of participants } \\
\text { and personnel (perfor- } \\
\text { mance bias) } \\
\text { All outcomes }\end{array}$ & Low risk & not described but judged low as outcome assessment well described \\
\hline
\end{tabular}

\begin{tabular}{|c|c|c|}
\hline $\begin{array}{l}\text { Blinding of outcome as- } \\
\text { sessment (detection bias) } \\
\text { All outcomes }\end{array}$ & Low risk & $\begin{array}{l}\text { "..one dedicated radiologist, blinded to the patient' treatment regimens, eval- } \\
\text { uated the venograms, while another assessed the sonographic data" }\end{array}$ \\
\hline $\begin{array}{l}\text { Incomplete outcome data } \\
\text { (attrition bias) }\end{array}$ & Low risk & no missing data \\
\hline
\end{tabular}


Schweizer 2000 (Continued)

All outcomes

Selective reporting (re- Low risk all outcomes reported

porting bias)

Other bias Low risk none

Tsapogas 1973

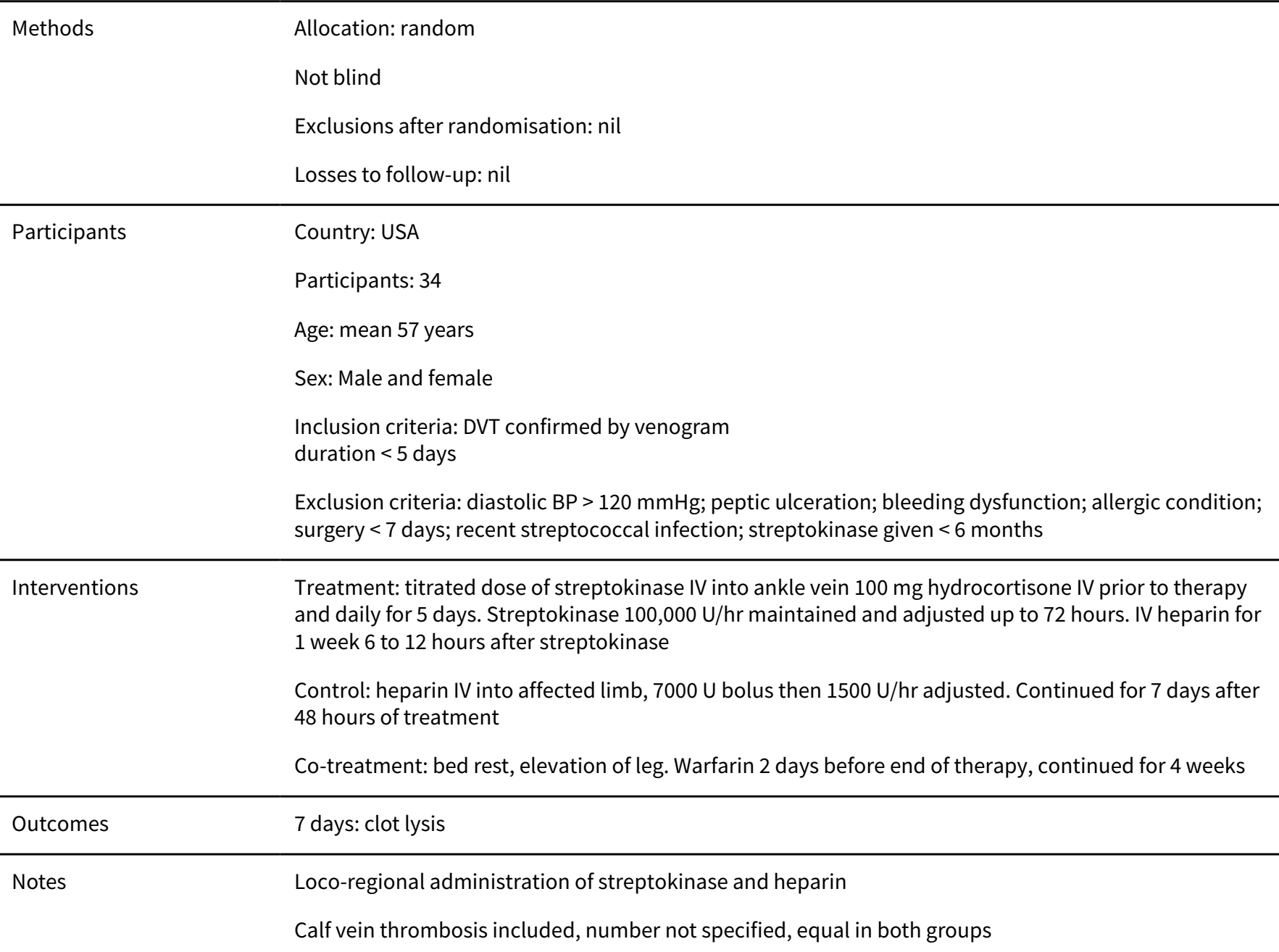

\section{Risk of bias}

\begin{tabular}{lll}
\hline Bias & Authors' judgement & Support for judgement \\
\hline $\begin{array}{l}\text { Random sequence genera- } \\
\text { tion (selection bias) }\end{array}$ & Low risk & "based on a list of random numbers" \\
\hline $\begin{array}{l}\text { Allocation concealment } \\
\text { (selection bias) }\end{array}$ & Unclear risk & "arranged by using sealed envelopes" \\
\hline $\begin{array}{l}\text { Blinding of participants } \\
\begin{array}{l}\text { and personnel (perfor- } \\
\text { mance bias) }\end{array}\end{array}$ & Unclear risk & not described \\
\hline
\end{tabular}


Tsapogas 1973 (Continued)

All outcomes

\begin{tabular}{lll}
\hline $\begin{array}{l}\text { Blinding of outcome as- } \\
\text { sessment (detection bias) } \\
\text { All outcomes }\end{array}$ & High risk & not described \\
\hline $\begin{array}{l}\text { Incomplete outcome data } \\
\begin{array}{l}\text { (attrition bias) } \\
\text { All outcomes }\end{array}\end{array}$ & Low risk & no missing data \\
\hline $\begin{array}{l}\text { Selective reporting (re- } \\
\text { porting bias) }\end{array}$ & Low risk & all outcomes reported \\
\hline Other bias & Low risk & none \\
\hline
\end{tabular}

\section{Turpie 1990}

\begin{tabular}{ll}
\hline Methods & Allocation: random \\
& Double blind \\
& Exclusions after randomisation: nil \\
Losses to follow-up: 37
\end{tabular}

Country: Canada
Participants: 83
Age: $<75$ years
Sex: not described
Inclusion criteria: venographically confirmed proximal DVT of lower limb
duration $<7$ days
Exclusion criteria: bleeding dysfunction; active bleeding; peptic ulcer; stroke or intracranial process $<2$
months; surgery, trauma, childbirth, biopsy, vessel puncture $<7$ days

Treatment: IV heparin $5000 \mathrm{U}$ bolus then $30,000 \mathrm{U} / 24$ hours, adjusted for 7 - 10 days
Phase 1 : two chain tPA $0.5 \mathrm{mg} / \mathrm{kg}$ IV over 4 hours
Phase 2 : one chain tPA $0.5 \mathrm{mg} / \mathrm{kg}$ IV over 8 hours and repeated in 24 hours
Control: identical placebo to tPA depending on phase, plus heparin as above
Co-treatment: warfarin commenced for 3 months

\begin{tabular}{ll}
\hline Outcomes & 24 - 48 hours: clot lysis; bleeding \\
& 3 years: post-thrombotic syndrome \\
\hline Notes & 22 died, 15 "not available" for intermediate to late follow-up
\end{tabular}

\section{Risk of bias}

\begin{tabular}{lll}
\hline Bias & Authors' judgement & Support for judgement \\
\hline $\begin{array}{l}\text { Random sequence genera- } \\
\text { tion (selection bias) }\end{array}$ & Unclear risk & "randomly allocated" no further details \\
\hline
\end{tabular}


Turpie 1990 (Continued)

\begin{tabular}{lll}
$\begin{array}{l}\text { Allocation concealment } \\
\text { (selection bias) }\end{array}$ & Unclear risk & not described clearly \\
\hline $\begin{array}{l}\text { Blinding of participants } \\
\text { and personnel (perfor- } \\
\text { mance bias) }\end{array}$ & Low risk & "identical appearing placebo" \\
All outcomes & &
\end{tabular}

\begin{tabular}{|c|c|c|}
\hline $\begin{array}{l}\text { Blinding of outcome as- } \\
\text { sessment (detection bias) }\end{array}$ & Low risk & $\begin{array}{l}\text { "venograms interpreted by an independent panel without knowledge of the } \\
\text { clinical findings or the treatment group" }\end{array}$ \\
\hline
\end{tabular}

All outcomes

Incomplete outcome data Low risk all reported
(attrition bias)

All outcomes

\begin{tabular}{lll}
\hline $\begin{array}{l}\text { Selective reporting (re- } \\
\text { porting bias) }\end{array}$ & Low risk & all reported \\
\hline Other bias & Low risk & none \\
\hline
\end{tabular}

Ugurlu 2002

\begin{tabular}{l} 
Pethods $\begin{array}{l}\text { Prospective study to compare efficacy and safety of low dose, slow infusion thrombolysis } \\
\text { Randomised }\end{array}$ \\
\hline
\end{tabular}

Country: Turkey
Age: 18 to 70 years
Number: 97,50 low dose strep, 47 hep
June 1995 to May 1999
Sex: Male and female
Informed consent
Baseline characteristics similar
Inclusion criteria: DVT confirmed with high resolution colour duplex
Exclusion criteria: history of stroke, intracranial haemorrhage, major GI, urological ir genital haemor-
rhage, major trauma or surgery within 20 days, hypertension, known bleeding diathesis, post partum,
nursing or pregnant women

Interventions

Strepokinase group: Methylprednisone $250 \mathrm{mg}$ IV with IV antihistaminic prior to 250,000 $\mathrm{U}$ given in 30 mins via forearm vein, then infusion of 100,000 U/hour. Infusion stopped when a dose of 1,500,000 $U$. Then heparin according to prothrombin and partial thromboplastin times and duplex study done. Urokinase administered in 2 patients who had severe allergic reaction to strep - bolus of $100,000 \mathrm{U}$ then infusion of 100,000 U per hour for a total dose of either 1,500,000 or 3,000,000 U

Heparin group: bolus of $5000 \mathrm{U}$, then infusion of 1-1500 U/hr. Dose adjusted according to the activated partial thromboplastin time

Both groups: bed rest and elevation, coumadin started 48 hours later according to prothrombin times, INR of 2 - 3 
Ugurlu 2002 (Continued)

Outcomes Venous flow, clinical assessment, haemorrhagic complications, allergic reaction

Notes Recurrent DVT included (30\% each group)

Risk of bias

\begin{tabular}{|c|c|c|}
\hline Bias & Authors' judgement & Support for judgement \\
\hline $\begin{array}{l}\text { Random sequence genera- } \\
\text { tion (selection bias) }\end{array}$ & Low risk & "randomised number table" \\
\hline $\begin{array}{l}\text { Allocation concealment } \\
\text { (selection bias) }\end{array}$ & Unclear risk & not mentioned \\
\hline $\begin{array}{l}\text { Blinding of participants } \\
\text { and personnel (perfor- } \\
\text { mance bias) } \\
\text { All outcomes }\end{array}$ & Low risk & not possible but judged low risk as outcome assessment well described \\
\hline $\begin{array}{l}\text { Blinding of outcome as- } \\
\text { sessment (detection bias) } \\
\text { All outcomes }\end{array}$ & Low risk & $\begin{array}{l}\text { "...initial and post-treatment duplex studies preformed by same radiologist } \\
\text { unaware of groups.." }\end{array}$ \\
\hline $\begin{array}{l}\text { Incomplete outcome data } \\
\text { (attrition bias) } \\
\text { All outcomes }\end{array}$ & Low risk & all accounted for \\
\hline $\begin{array}{l}\text { Selective reporting (re- } \\
\text { porting bias) }\end{array}$ & Low risk & all outcomes reported \\
\hline Other bias & Low risk & none \\
\hline
\end{tabular}

\section{Verhaeghe 1989}

\begin{tabular}{ll}
\hline Methods & Allocation: random \\
& Double blind \\
& Exclusions after randomisation: nil \\
Losses to follow-up: nil
\end{tabular}

\section{Participants}

Country: France, Belgium, Switzerland

Participants: 21 (in randomised phase only)

Age: 22 to 74 years

Sex: Male and female

Inclusion criteria: hospitalised patients with DVT of popliteal or more proximal veins of the lower leg, confirmed by venography

duration $<10$ days

Exclusion criteria: pregnancy; major surgery $<72$ hours; stroke $<6$ months; head trauma $<1$ month; diastolic BP > $120 \mathrm{mmHg}$; renal/hepatic disease; peptic ulcer; bleeding dysfunction; contraindication to heparin 
Verhaeghe 1989 (Continued)

Interventions

Treatment: (2 groups)

IV tPA $100 \mathrm{mg}$ on day $1,50 \mathrm{mg}$ tPA on day $2.10 \%$ of dose given as bolus

IV tPA $50 \mathrm{mg}$ on day 1 , repeated on day $2.10 \%$ of dose given as bolus

Control:

identical placebo infusion as above

Co-treatment: heparin $5000 \mathrm{U}$ IV bolus then continuous infusion of $1000 \mathrm{U}$ per hour for up to 72 hours

\begin{tabular}{ll}
\hline Outcomes & 72 hours: clot lysis; bleeding \\
\hline Notes & Included initial open label phase in some results (11 additional patients)
\end{tabular}

\section{Risk of bias}

\begin{tabular}{lll}
\hline Bias & Authors' judgement & Support for judgement \\
\hline $\begin{array}{l}\text { Random sequence genera- } \\
\text { tion (selection bias) }\end{array}$ & Unclear risk & "randomly allotted" not described further \\
\hline $\begin{array}{l}\text { Allocation concealment } \\
\text { (selection bias) }\end{array}$ & Unclear risk & not clearly described \\
\hline $\begin{array}{l}\text { Blinding of participants } \\
\text { and personnel (perfor- } \\
\text { mance bias) }\end{array}$ & Low risk & "double-blind" \\
All outcomes & \\
\hline
\end{tabular}

\begin{tabular}{lll}
\hline $\begin{array}{l}\text { Blinding of outcome as- } \\
\text { sessment (detection bias) } \\
\text { All outcomes }\end{array}$ & Low risk & $\begin{array}{l}\text { "Two radiologists interpreted all films without knowing the drug administered } \\
\text { or whether the venography was before or after trial treatment" }\end{array}$ \\
\hline $\begin{array}{l}\text { Incomplete outcome data } \\
\begin{array}{l}\text { (attrition bias) } \\
\text { All outcomes }\end{array}\end{array}$ & Low risk & "no protocol violations" \\
\hline $\begin{array}{l}\text { Selective reporting (re- } \\
\text { porting bias) }\end{array}$ & Low risk & all outcomes reported \\
\hline Other bias & Low risk & none \\
\hline
\end{tabular}

BP: blood pressure

CDT: catheter-directed thrombolysis

CNS: central nervous system

CVA: cerebrovascular accident

DVT: deep vein thrombosis

$\mathrm{Gl}$ : gastrointestinal

GU: genitourinary

hep: heparin

Hg: mercury

IM: intramuscular

IU: international unit

PE: pulmonary embolism

strep: streptokinase

TB: tuberculosis

tPA: tissue plasminogen activator 
U: unit

Characteristics of excluded studies [ordered by study ID]

\begin{tabular}{|c|c|}
\hline Study & Reason for exclusion \\
\hline Ansell 1990 & Insufficient information despite contacting author \\
\hline Bashir 2014 & Not randomised \\
\hline Bieger 1976 & DVT not confirmed objectively \\
\hline Browse 1968 & Not randomised \\
\hline Cakir 2014 & Thrombectomy not thrombolysis \\
\hline Engelberger 2015 & Not CDT versus anticoagulant \\
\hline Johansson 1979 & Not truly randomised \\
\hline Marini 1991 & Both groups received thrombolysis \\
\hline Markevicius 2004 & Not truly randomised \\
\hline Patra 2014 & Included patients with DVT 0 - 8 weeks, not clear if randomised, CDT in addition to thrombectomy \\
\hline Persson 1977 & Insufficient information, unable to contact author \\
\hline Pinto 1997 & No thrombolytic \\
\hline Robertson 1967 & Not truly randomised \\
\hline Santiago 2014 & Prospective observational clinical study in children only \\
\hline Sas 1985 & Insufficient information, unable to contact author \\
\hline Schweizer 1996 & Control group not randomised \\
\hline Silistreli 2004 & Included patients with symptoms for more than 21 days \\
\hline Sui 2013 & Compares thrombolytics, not CDT versus anticoagulant \\
\hline Tibbutt 1974 & Ancrod used as control \\
\hline Tibbutt 1977 & All patients received streptokinase \\
\hline TORPEDO 2012 & Only 33 out of 90 patients received thrombolysis \\
\hline Zhang 2014 & CDT verses CDT plus angioplasty \\
\hline Zimmermann 1986 & Both groups received thrombolysis \\
\hline
\end{tabular}

DVT: deep vein thrombosis

Characteristics of ongoing studies [ordered by study ID] 
IRCT201108035625N3

Trial name or title Traditional medical treatment versus interventional approach in acute iliofemoral vein thrombosis

Methods

Single centre randomised controlled clinical trial comparing the effect of conventional therapy (heparin followed by warfarin) with interventional therapy (thrombolysis with or without angioplasty and stenting) on venous patency in patients admitted with acute iliofemoral DVT to Tehran Heart Center emergency department

\section{Participants}

Patients with acute extensive iliofemoral venous thrombosis

Interventions

Intervention: lytic therapy will be achieved by placing a catheter in the contralateral femoral vein, the right internal jugular vein, or the ipsilateral popliteal vein for direct intra-clot infusion. Streptokinase will be given as a loading dose of 250,000 units followed by infusion of 100,000 units per hour for 24 to 48 hours. Heparin will be administered concomitantly with the lytic therapy and continued until therapeutic anticoagulation with warfarin will be accomplished. After lytic therapy, further intervention (PTA/stenting) will be performed if there is an underlying venous stenosis of $50 \%$ or more. Stent placement will be done with appropriate selected stents (self-expanding stainless steel wall stents). All stented patients will be given warfarin indefinitely (INR $2-3$ ). Lysis will be considered complete if there is less than $5 \%$ residual thrombus

Control: conventional treatment will consist of intravenous heparin followed by warfarin. All patients will be treated with limb elevation and moist heat during their initial admission and maintained on prescription gradient compression stockings

\begin{tabular}{ll}
\hline Outcomes & Venous patency and symptom changes \\
\hline Starting date & August 2011 \\
\hline Contact information & Dr Yaser Jenab Tehran Heart Center jenab@razi.tums.ac.ir \\
\hline Notes & $\begin{array}{l}\text { http://www.irct.ir/searchresult.php?keyword=\&id=5625\&number=3\&prt=2274\&total=10\&m=1 (ac- } \\
\text { cessed 29/02/2016) }\end{array}$ \\
\hline
\end{tabular}

\section{NCT00790335}

Trial name or title Acute Venous Thrombosis: Thrombus removal with adjunctive catheter-directed thrombolysis (ATTRACT)

\begin{tabular}{ll}
\hline Methods & Optimal standard DVT therapy to standard plus CDT \\
\hline Participants & $\begin{array}{l}\text { Age } 16 \text { to } 75 \text { years old with symptomatic proximal DVT involving iliac, common femoral and or } \\
\text { femoral vein }\end{array}$ \\
\hline Interventions & Recombinant tissue plasminogen activator (rt-PA) \\
\hline Outcomes & Incidence of post-thrombotic syndrome 24 months after intervention; major bleeding \\
\hline Starting date & November 2009 \\
\hline Contact information & Patty M Nieters nietersp@mir.wustl.edu \\
\hline Notes & NCT00790335 \\
\hline
\end{tabular}




\section{NCT00970619}

Trial name or title

Methods

Methods
DUTCH CAVA-trial: CAtheter Versus Anticoagulation Alone for Acute Primary (Ilio)Femoral DVT. (NL28394)

Study design: prospective, non blinded, randomised, controlled, multicentre, intervention study. To assess whether catheter directed thrombolytic therapy for the treatment of IFDVT can safely and effectively reduce post thrombotic morbidity after one year. The secondary objective is to study whether catheter directed thrombolytic intervention has a positive effect on the quality of life of patients with IFDVT and to assess late PTS

\begin{tabular}{|c|c|}
\hline Participants & $\begin{array}{l}\text { The study population includes all consecutive patients with IFDVT presenting at the emergency or } \\
\text { outpatient departments of the participating centres. The thrombus should not be older than } 14 \\
\text { days at randomisation }\end{array}$ \\
\hline Interventions & $\begin{array}{l}\text { After randomisation patients will be allocated to either conservative anticoagulant treatment or to } \\
\text { catheter directed thrombolysis combined with conservative anticoagulant treatment }\end{array}$ \\
\hline Outcomes & $\begin{array}{l}\text { The primary efficacy outcome is the incidence of PTS at one year; a decline in PTS incidence from } \\
25 \% \text { to } 8 \% \text { is anticipated. The secondary outcome is the Health related Quality of life and late } \\
\text { PTS during follow-up. The principal safety outcome is major bleeding during anticoagulant ther- } \\
\text { apy. Bleeding as well as events of recurrent thrombosis will be monitored. The patency of the ve- } \\
\text { nous system of the affected lower limb will be assessed as well as the percentage of clot lysis, after } \\
\text { thrombolytic intervention. Additionally, measurements of markers of coagulation and inflamma- } \\
\text { tion will be performed during follow-up }\end{array}$ \\
\hline Starting date & May 2010 \\
\hline Contact information & Rob Strijkers, MD \\
\hline Notes & NCT00970619 \\
\hline
\end{tabular}

CDT: catheter-directed thrombolysis

DVT: deep vein thrombosis

IFDVT: ileofemoral deep vein thrombosis

INR: international normalised ratio

PTA: percutaneous transluminal angioplasty

PTS: post-thrombotic syndrome

\section{DATA AND ANALYSES}

\section{Comparison 1. Any thrombolysis versus control}

\begin{tabular}{|c|c|c|c|c|}
\hline Outcome or subgroup title & $\begin{array}{l}\text { No. of } \\
\text { studies }\end{array}$ & $\begin{array}{l}\text { No. of } \\
\text { partici- } \\
\text { pants }\end{array}$ & Statistical method & Effect size \\
\hline 1 Any improvement in venous patency (early) & 9 & 421 & $\begin{array}{l}\text { Risk Ratio (M-H, Random, } \\
95 \% \mathrm{Cl})\end{array}$ & $2.48[1.35,4.57]$ \\
\hline 2 Complete clot lysis (early) & 8 & 592 & $\begin{array}{l}\text { Risk Ratio (M-H, Random, } \\
95 \% \mathrm{Cl})\end{array}$ & $4.91[1.66,14.53]$ \\
\hline 3 Bleeding (early) & 17 & 1103 & $\begin{array}{l}\text { Risk Ratio (M-H, Fixed, 95\% } \\
\mathrm{CI})\end{array}$ & $2.23[1.41,3.52]$ \\
\hline
\end{tabular}




\begin{tabular}{|c|c|c|c|c|}
\hline Outcome or subgroup title & $\begin{array}{l}\text { No. of } \\
\text { studies }\end{array}$ & $\begin{array}{l}\text { No. of } \\
\text { partici- } \\
\text { pants }\end{array}$ & Statistical method & Effect size \\
\hline 4 Stroke/intracerebral haemorrhage (early) & 17 & 1103 & $\begin{array}{l}\text { Risk Ratio (M-H, Fixed, 95\% } \\
\mathrm{Cl})\end{array}$ & $1.92[0.34,10.86]$ \\
\hline 5 Mortality (early) & 9 & 529 & $\begin{array}{l}\text { Risk Ratio (M-H, Fixed, 95\% } \\
\mathrm{Cl})\end{array}$ & $0.76[0.31,1.89]$ \\
\hline 6 Pulmonary embolism (early) & 6 & 433 & $\begin{array}{l}\text { Risk Ratio (M-H, Fixed, 95\% } \\
\mathrm{Cl} \text { ) }\end{array}$ & $1.00[0.33,3.05]$ \\
\hline 7 Post-thrombotic syndrome (intermediate) & 3 & 306 & $\begin{array}{l}\text { Risk Ratio (M-H, Fixed, 95\% } \\
\mathrm{Cl} \text { ) }\end{array}$ & $0.66[0.53,0.81]$ \\
\hline 8 Post-thrombotic syndrome (late) & 2 & 211 & $\begin{array}{l}\text { Risk Ratio (M-H, Fixed, 95\% } \\
\text { Cl) }\end{array}$ & $0.58[0.45,0.77]$ \\
\hline 9 Leg ulceration (intermediate) & 4 & 342 & $\begin{array}{l}\text { Risk Ratio (M-H, Fixed, 95\% } \\
\mathrm{Cl} \text { ) }\end{array}$ & $0.87[0.16,4.73]$ \\
\hline 10 Leg ulceration (late) & 1 & & $\begin{array}{l}\text { Risk Ratio (M-H, Fixed, 95\% } \\
\mathrm{Cl} \text { ) }\end{array}$ & Totals not selected \\
\hline 11 Complete clot lysis (intermediate) & 7 & 630 & $\begin{array}{l}\text { Risk Ratio (M-H, Random, } \\
95 \% \mathrm{Cl})\end{array}$ & $2.44[1.40,4.27]$ \\
\hline 12 Complete clot lysis (late) & 2 & 206 & $\begin{array}{l}\text { Risk Ratio (M-H, Random, } \\
95 \% \mathrm{Cl})\end{array}$ & $3.25[0.17,62.63]$ \\
\hline 13 Mortality (intermediate) & 2 & 289 & $\begin{array}{l}\text { Risk Ratio (M-H, Fixed, 95\% } \\
\mathrm{Cl} \text { ) }\end{array}$ & $0.96[0.27,3.43]$ \\
\hline 14 Mortality (late) & 2 & 230 & $\begin{array}{l}\text { Risk Ratio (M-H, Fixed, 95\% } \\
\mathrm{Cl})\end{array}$ & $0.61[0.25,1.50]$ \\
\hline 15 Normal venous function (intermediate) & 3 & 255 & $\begin{array}{l}\text { Risk Ratio (M-H, Random, } \\
95 \% \mathrm{Cl})\end{array}$ & $2.18[0.86,5.54]$ \\
\hline 16 Recurrent DVT (intermediate) & 1 & & $\begin{array}{l}\text { Risk Ratio (M-H, Fixed, 95\% } \\
\mathrm{Cl} \text { ) }\end{array}$ & Totals not selected \\
\hline
\end{tabular}

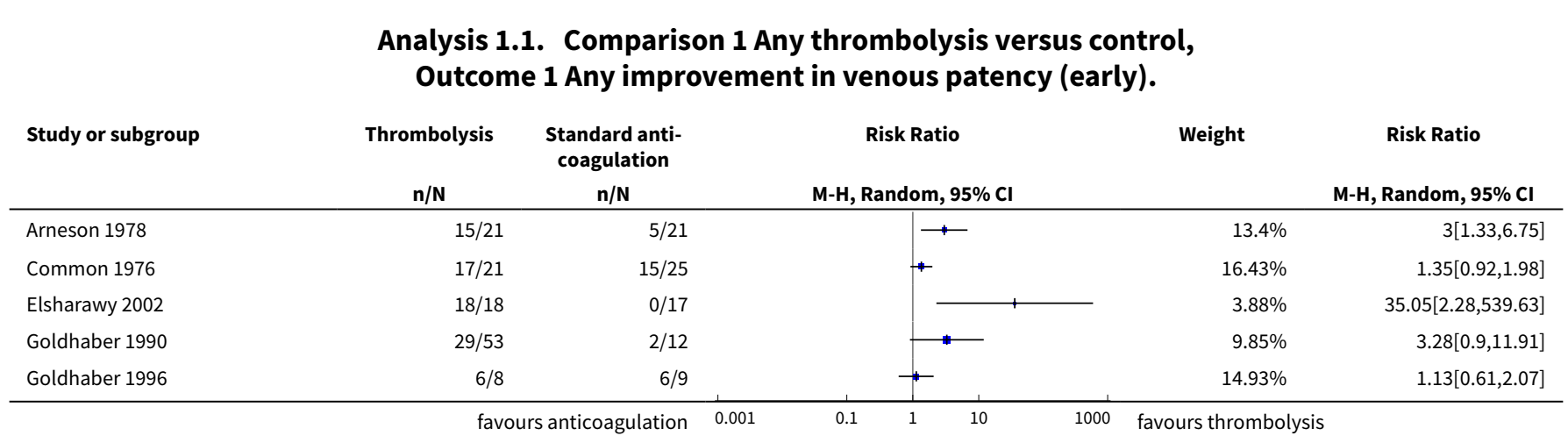




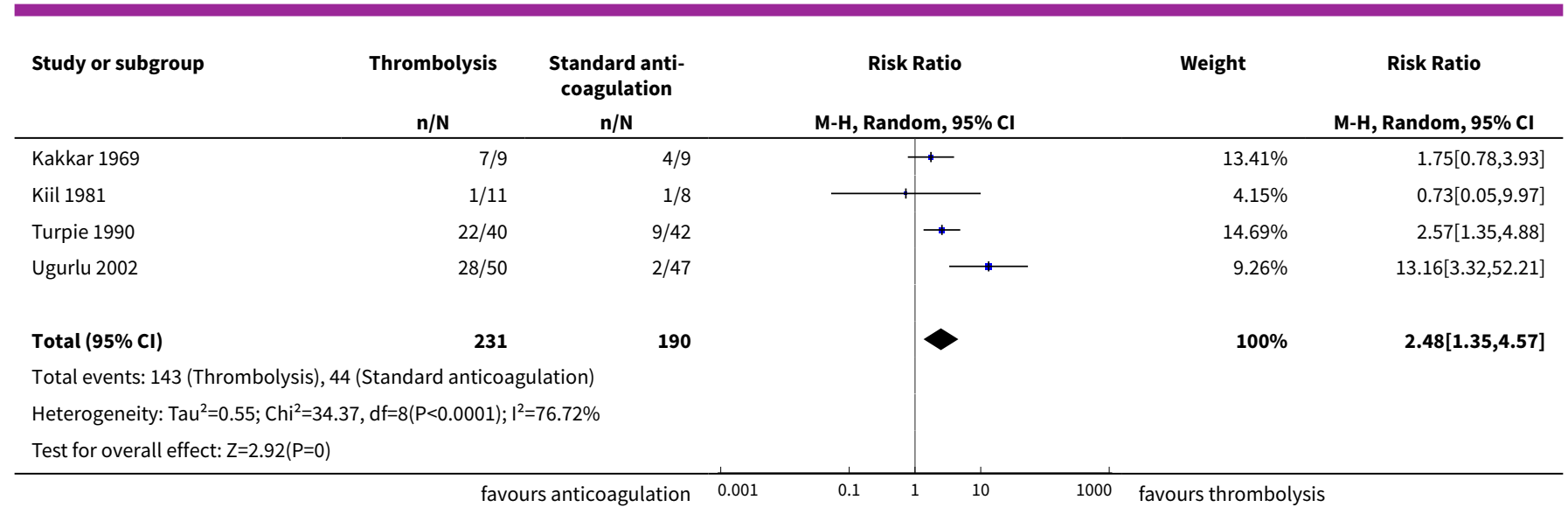

\section{Analysis 1.2. Comparison 1 Any thrombolysis versus control, Outcome 2 Complete clot lysis (early).}

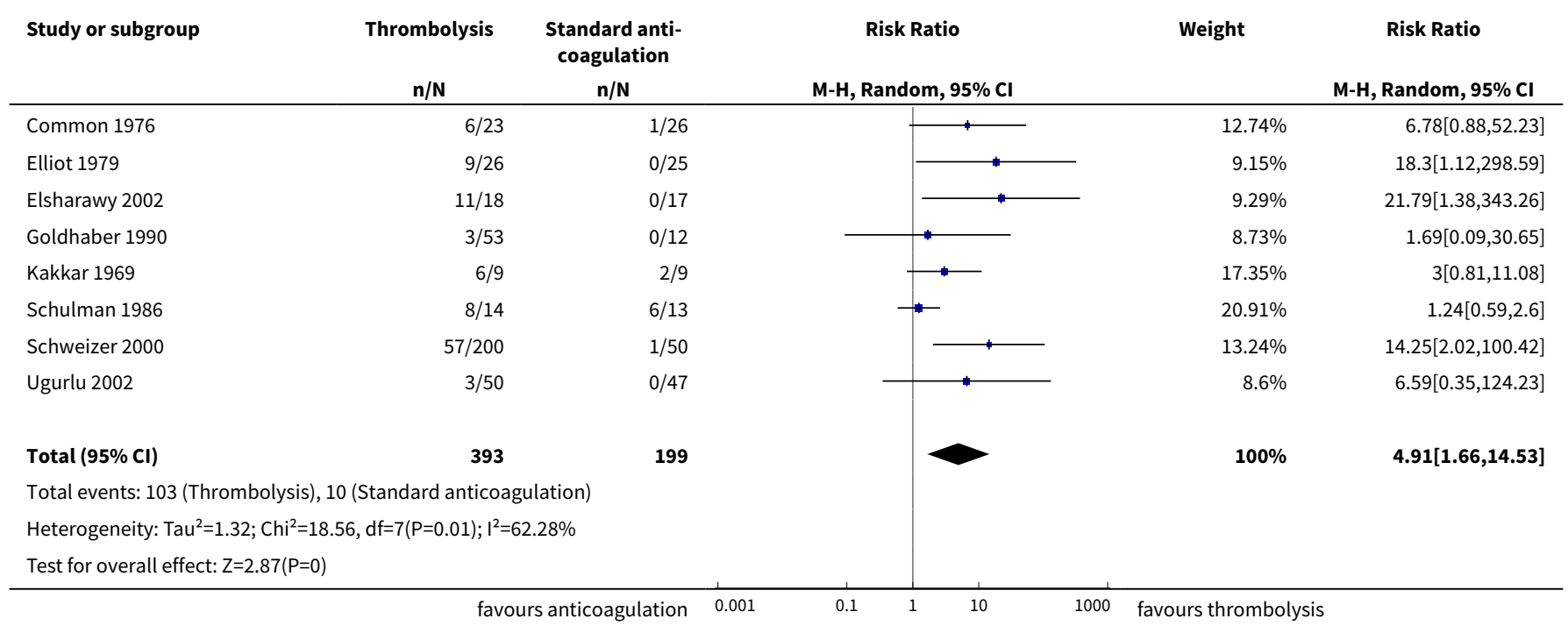

Analysis 1.3. Comparison 1 Any thrombolysis versus control, Outcome 3 Bleeding (early).

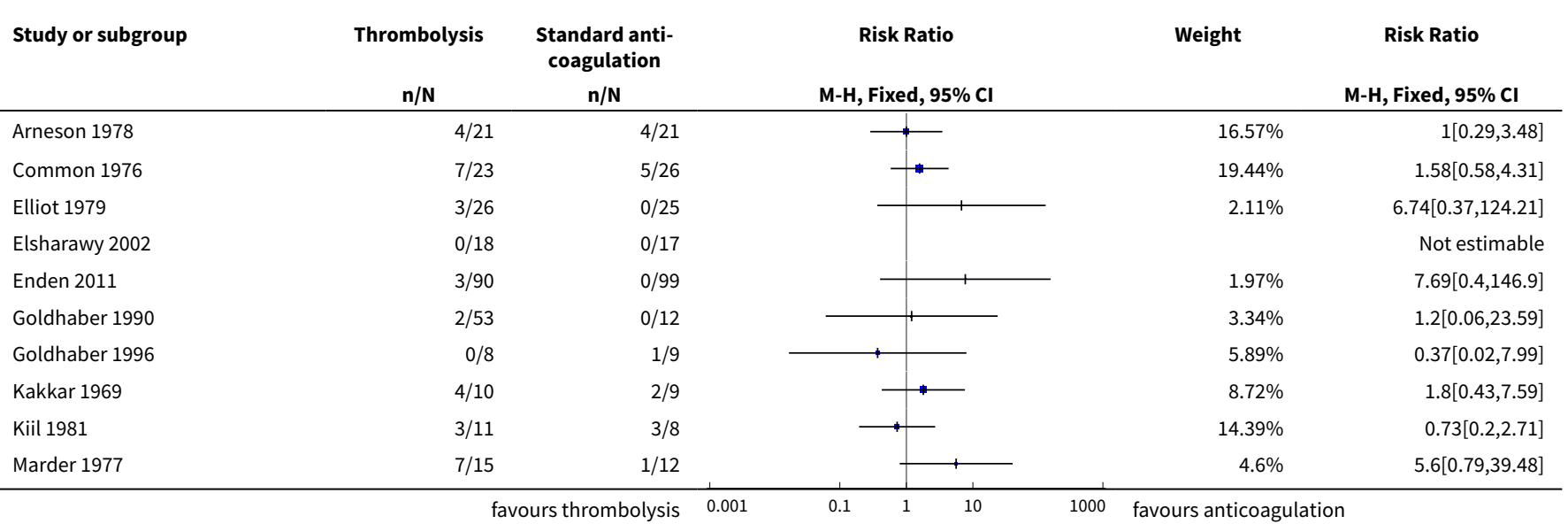




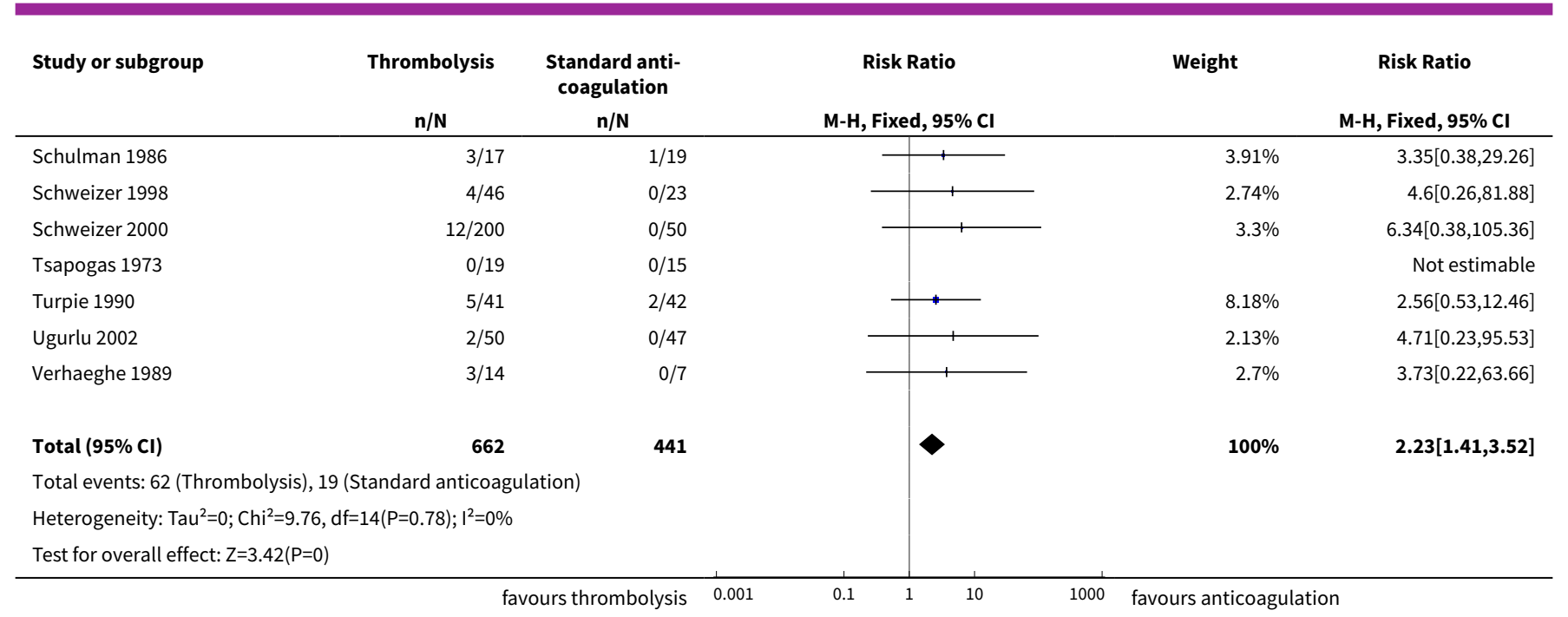

Analysis 1.4. Comparison 1 Any thrombolysis versus control, Outcome 4 Stroke/intracerebral haemorrhage (early).

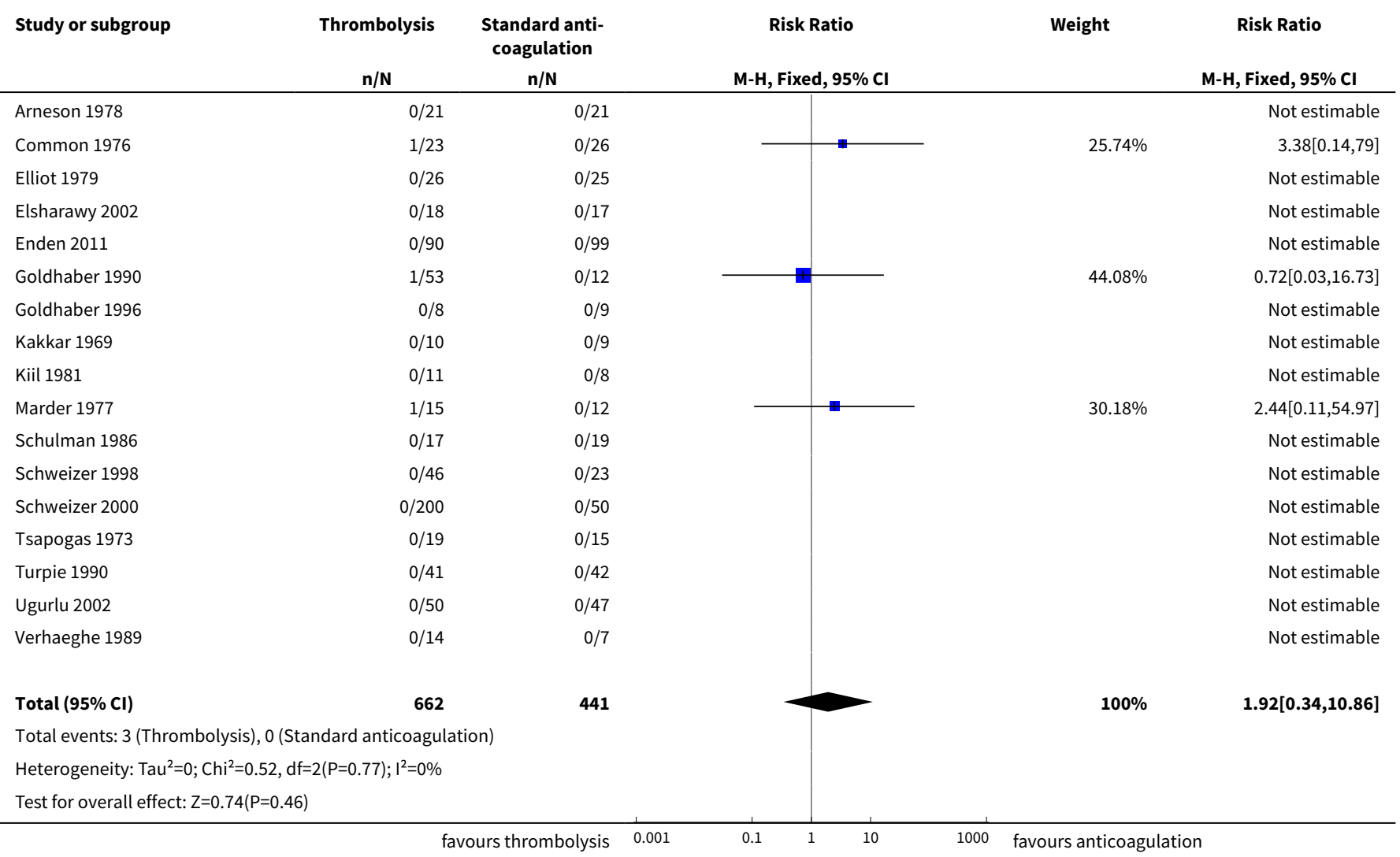


Analysis 1.5. Comparison 1 Any thrombolysis versus control, Outcome 5 Mortality (early).

\begin{tabular}{|c|c|c|c|c|c|}
\hline \multirow[t]{2}{*}{ Study or subgroup } & Thrombolysis & $\begin{array}{l}\text { Standard anti- } \\
\text { coagulation }\end{array}$ & Risk Ratio & \multirow[t]{2}{*}{ Weight } & \multirow{2}{*}{$\begin{array}{l}\text { Risk Ratio } \\
\text {, Fixed, } 95 \% \mathrm{CI}\end{array}$} \\
\hline & $n / N$ & $n / N$ & M-H, Fixed, 95\% Cl & & \\
\hline Arneson 1978 & $0 / 21$ & $1 / 21$ & 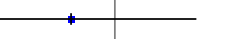 & $15.42 \%$ & $0.33[0.01,7.74]$ \\
\hline Common 1976 & $1 / 23$ & $0 / 26$ & 1 & $4.84 \%$ & $3.38[0.14,79]$ \\
\hline Elliot 1979 & $0 / 26$ & $2 / 25$ & & $26.18 \%$ & $0.19[0.01,3.82]$ \\
\hline Elsharawy 2002 & $0 / 18$ & $0 / 17$ & & & Not estimable \\
\hline Kiil 1981 & $0 / 11$ & $1 / 8$ & & $17.62 \%$ & $0.25[0.01,5.45]$ \\
\hline Marder 1977 & $1 / 15$ & $0 / 12$ & & $5.67 \%$ & $2.44[0.11,54.97]$ \\
\hline Schulman 1986 & $1 / 17$ & $1 / 19$ & & $9.71 \%$ & $1.12[0.08,16.52]$ \\
\hline Schweizer 2000 & $0 / 200$ & $0 / 50$ & & & Not estimable \\
\hline Total $(95 \% \mathrm{Cl})$ & 341 & 188 & & $100 \%$ & $0.76[0.31,1.89]$ \\
\hline \multicolumn{6}{|c|}{ Heterogeneity: $\operatorname{Tau}^{2}=0 ; \mathrm{Chi}^{2}=3.14, \mathrm{df}=6(\mathrm{P}=0.79) ; \mathrm{I}^{2}=0 \%$} \\
\hline Test for overall effec & & & & & \\
\hline
\end{tabular}

\section{Analysis 1.6. Comparison 1 Any thrombolysis versus control, Outcome 6 Pulmonary embolism (early).}

\begin{tabular}{|c|c|c|c|c|c|}
\hline \multirow[t]{2}{*}{ Study or subgroup } & \multirow{2}{*}{$\begin{array}{c}\text { Thrombolysis } \\
\mathrm{n} / \mathrm{N} \\
\end{array}$} & \multirow{2}{*}{$\begin{array}{c}\text { Standard anti- } \\
\text { coagulation } \\
n / N \\
\end{array}$} & \multirow{2}{*}{$\begin{array}{c}\text { Risk Ratio } \\
\text { M-H, Fixed, } 95 \% \mathrm{Cl}\end{array}$} & \multirow[t]{2}{*}{ Weight } & \multirow{2}{*}{$\begin{array}{c}\text { Risk Ratio } \\
\text { M-H, Fixed, 95\% Cl } \\
\end{array}$} \\
\hline & & & & & \\
\hline Arneson 1978 & $1 / 21$ & $1 / 21$ & & $14.69 \%$ & $1[0.07,14.95]$ \\
\hline Elsharawy 2002 & $0 / 18$ & $1 / 17$ & & $22.64 \%$ & $0.32[0.01,7.26]$ \\
\hline Elliot 1979 & $1 / 26$ & $2 / 25$ & $\because$ & $29.96 \%$ & $0.48[0.05,4.98]$ \\
\hline Kakkar 1969 & $0 / 9$ & $1 / 10$ & & $20.99 \%$ & $0.37[0.02,8.01]$ \\
\hline Schweizer 2000 & $9 / 200$ & $0 / 50$ & $\longrightarrow$ & $11.72 \%$ & $4.82[0.29,81.46]$ \\
\hline Total $(95 \% \mathrm{Cl})$ & 291 & 142 & & $100 \%$ & $1[0.33,3.05]$ \\
\hline \multicolumn{6}{|c|}{ Total events: 11 (Thrombolysis), 5 (Standard anticoagulation) } \\
\hline \multicolumn{6}{|c|}{ Heterogeneity: $\mathrm{Tau}^{2}=0 ; \mathrm{Chi}^{2}=2.5, \mathrm{df}=4(\mathrm{P}=0.65) ; \mathrm{I}^{2}=0 \%$} \\
\hline Test for overall effect & & & & & \\
\hline
\end{tabular}

Analysis 1.7. Comparison 1 Any thrombolysis versus control, Outcome 7 Post-thrombotic syndrome (intermediate).

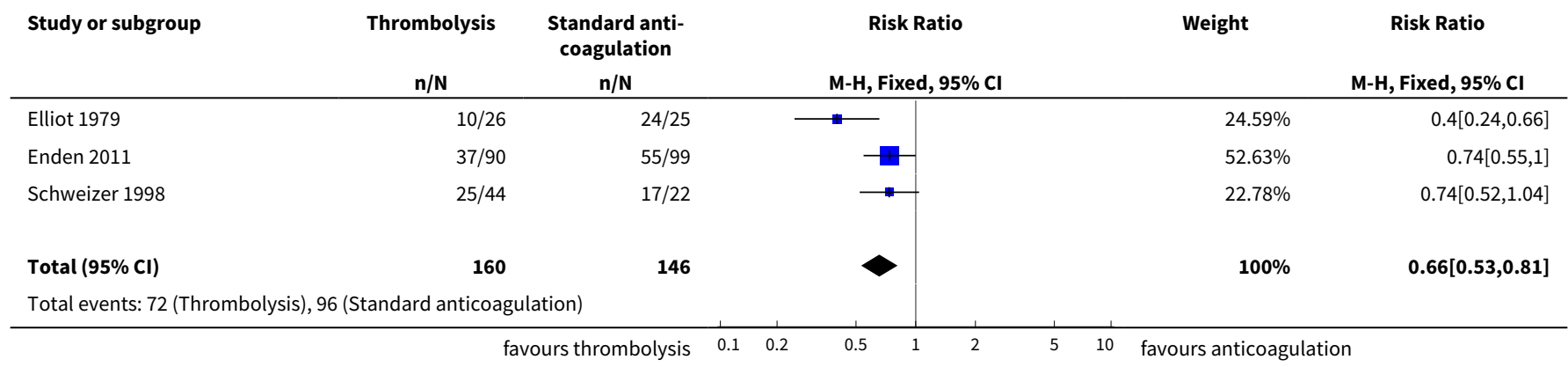




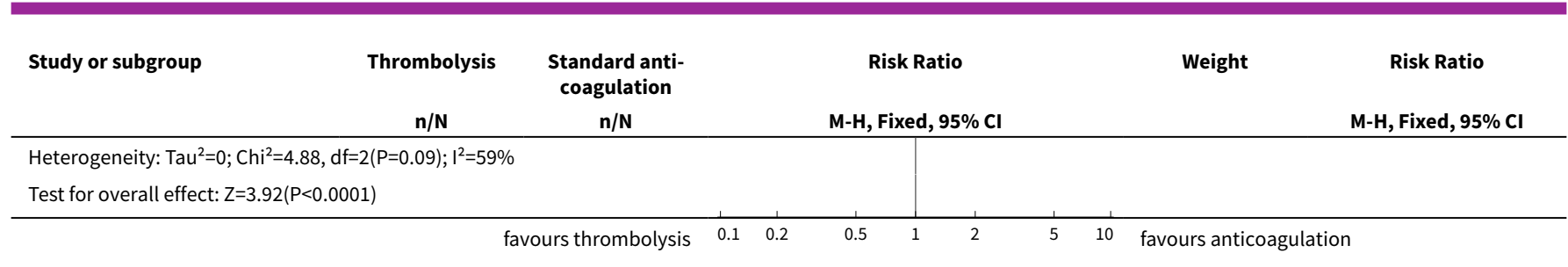

Analysis 1.8. Comparison 1 Any thrombolysis versus control, Outcome 8 Post-thrombotic syndrome (late).

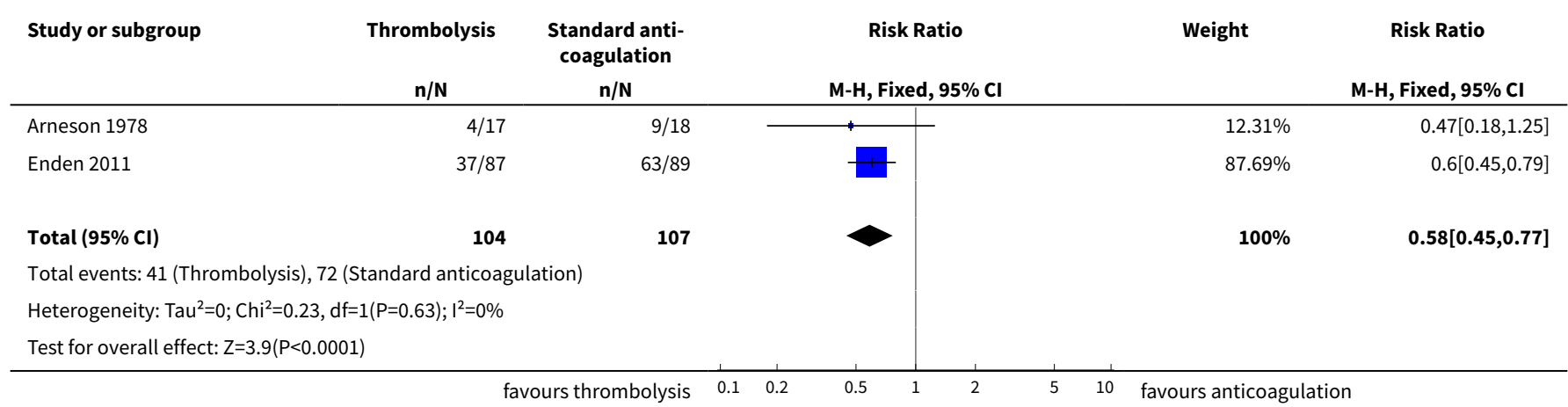

Analysis 1.9. Comparison 1 Any thrombolysis versus control, Outcome 9 Leg ulceration (intermediate).

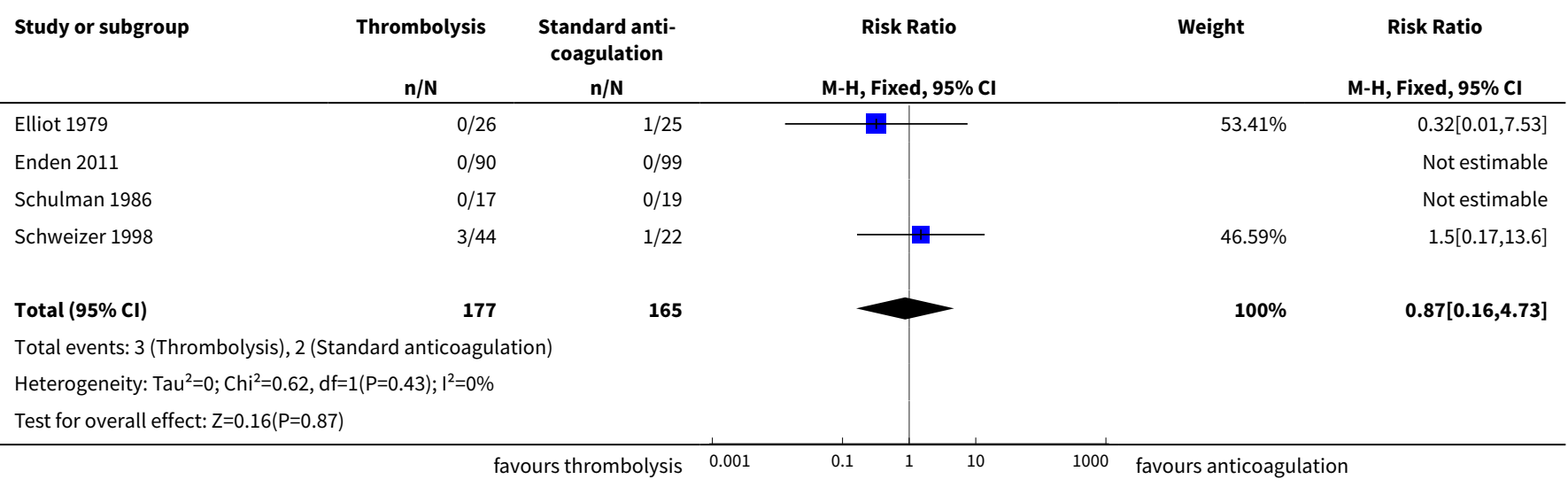

Analysis 1.10. Comparison 1 Any thrombolysis versus control, Outcome 10 Leg ulceration (late).

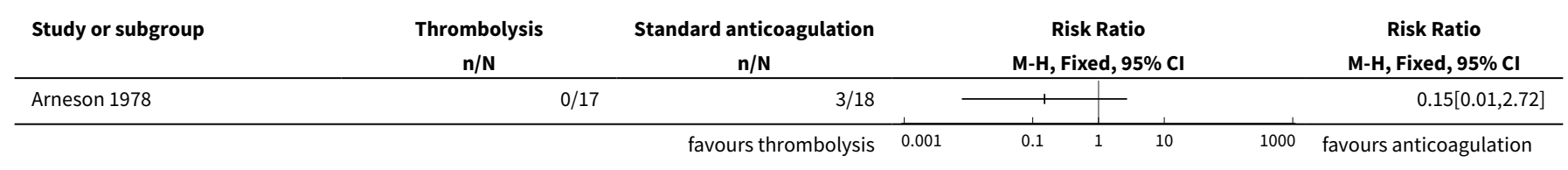


Analysis 1.11. Comparison 1 Any thrombolysis versus control, Outcome 11 Complete clot lysis (intermediate).

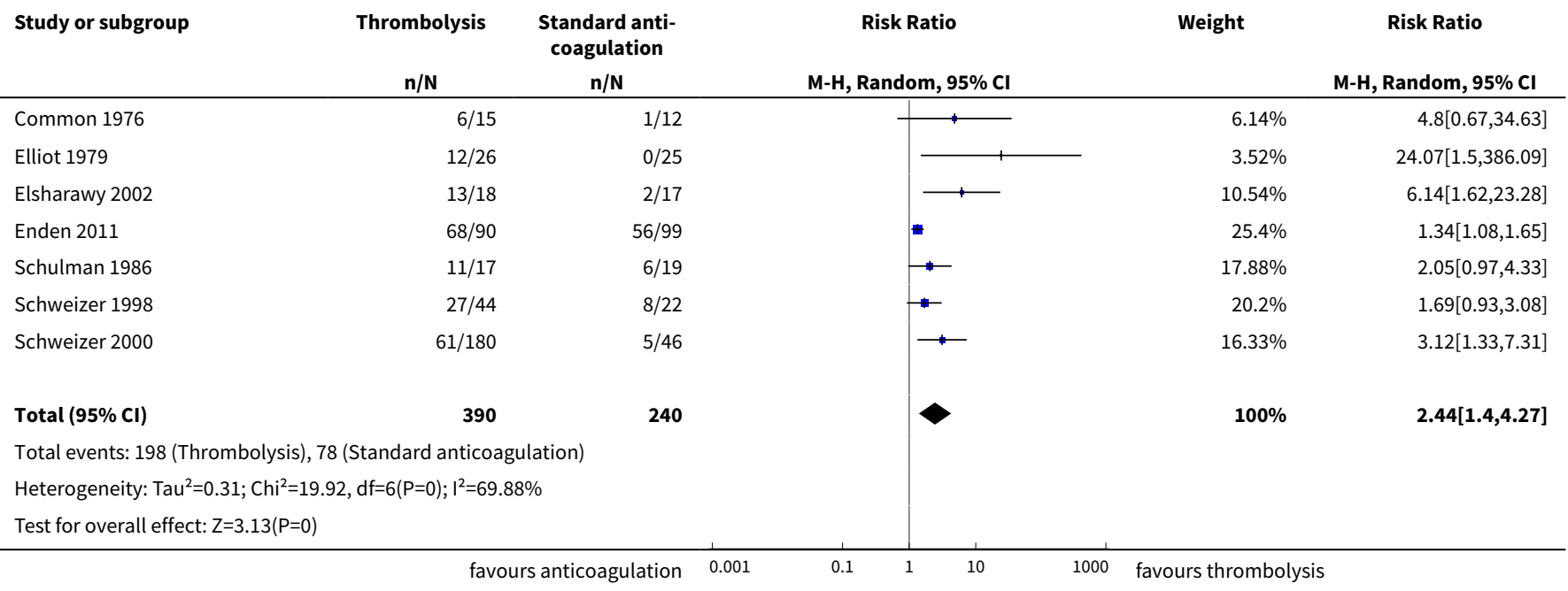

Analysis 1.12. Comparison 1 Any thrombolysis versus control, Outcome 12 Complete clot lysis (late).

\begin{tabular}{|c|c|c|c|c|c|}
\hline \multirow[t]{2}{*}{ Study or subgroup } & Thrombolysis & $\begin{array}{l}\text { Standard anti- } \\
\text { coagulation }\end{array}$ & Risk Ratio & Weight & \multirow{2}{*}{$\begin{array}{c}\text { Risk Ratio } \\
\text { M-H, Random, } 95 \% \mathrm{CI}\end{array}$} \\
\hline & $n / N$ & $n / N$ & \multicolumn{2}{|l|}{ M-H, Random, 95\% Cl } & \\
\hline Arneson 1978 & $7 / 16$ & $0 / 18$ & 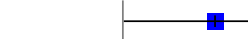 & $39.45 \%$ & $16.76[1.03,272.11]$ \\
\hline Enden 2011 & $68 / 86$ & $61 / 86$ & & $60.55 \%$ & $1.11[0.94,1.33]$ \\
\hline Total $(95 \% \mathrm{Cl})$ & 102 & 104 & & $100 \%$ & $3.25[0.17,62.63]$ \\
\hline \multicolumn{6}{|c|}{ Heterogeneity: Tau $^{2}=3.76 ; \mathrm{Chi}^{2}=4.7, \mathrm{df}=1(\mathrm{P}=0.03) ; \mathrm{I}^{2}=78.73 \%$} \\
\hline \multicolumn{6}{|c|}{ Test for overall effect: $\mathrm{Z}=0.78(\mathrm{P}=0.44)$} \\
\hline
\end{tabular}

\section{Analysis 1.13. Comparison 1 Any thrombolysis versus control, Outcome 13 Mortality (intermediate).}

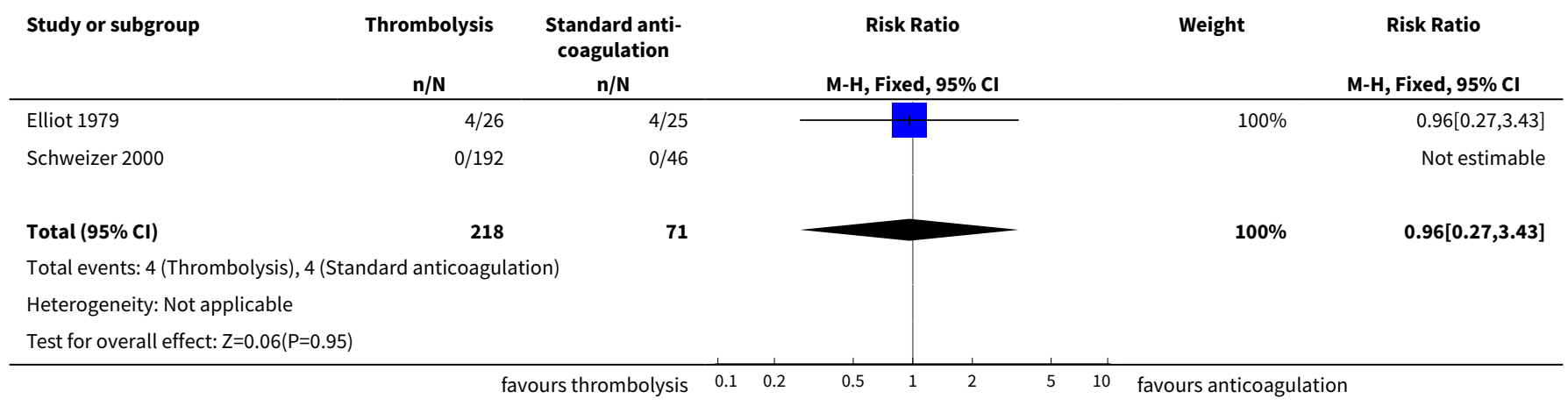


Analysis 1.14. Comparison 1 Any thrombolysis versus control, Outcome 14 Mortality (late).

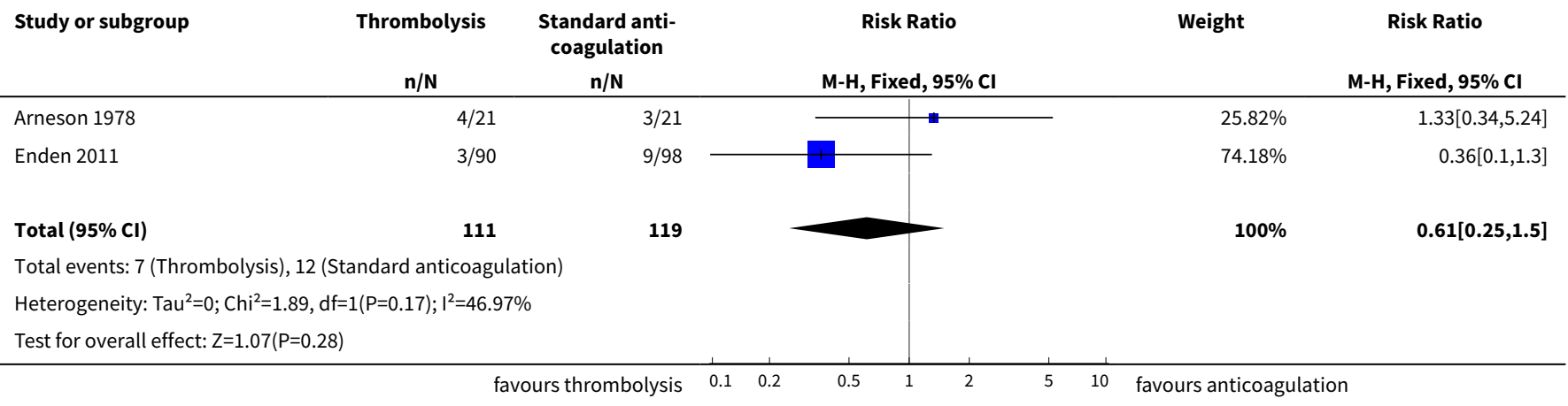

Analysis 1.15. Comparison 1 Any thrombolysis versus control, Outcome 15 Normal venous function (intermediate).

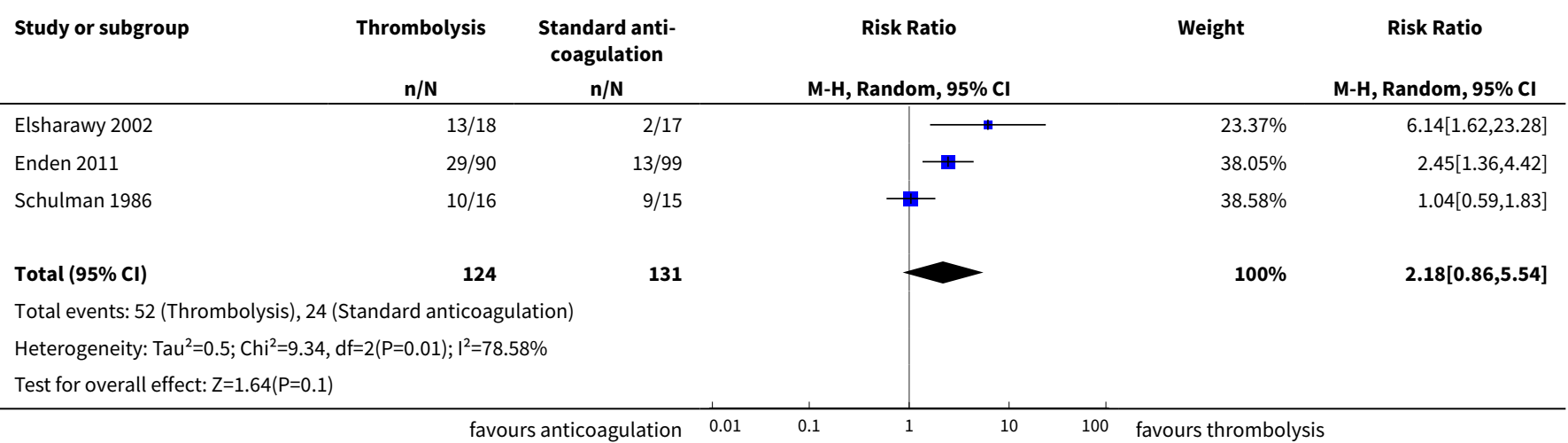

Analysis 1.16. Comparison 1 Any thrombolysis versus control, Outcome 16 Recurrent DVT (intermediate).

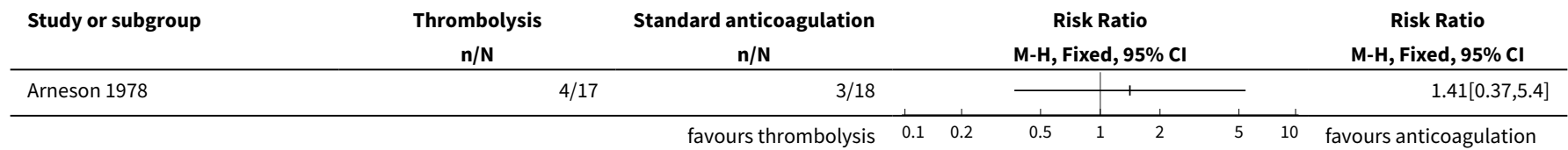

\section{Comparison 2. Systemic thrombolysis versus control}

\begin{tabular}{lllll}
\hline Outcome or subgroup title & $\begin{array}{l}\text { No. of } \\
\text { studies }\end{array}$ & $\begin{array}{l}\text { No. of } \\
\text { partici- } \\
\text { pants }\end{array}$ & Statistical method & Effect size \\
\hline 1 Any improvement in venous patency (early) & 8 & 386 & $\begin{array}{l}\text { Risk Ratio (M-H, Random, } \\
95 \% \mathrm{Cl})\end{array}$ & $2.18[1.28,3.70]$ \\
\hline 2 Complete clot lysis (early) & 7 & 457 & $\begin{array}{l}\text { Risk Ratio (M-H, Random, } \\
95 \% \mathrm{Cl})\end{array}$ & $4.37[1.40,13.61]$ \\
\hline
\end{tabular}




\begin{tabular}{|c|c|c|c|c|}
\hline Outcome or subgroup title & $\begin{array}{l}\text { No. of } \\
\text { studies }\end{array}$ & $\begin{array}{l}\text { No. of } \\
\text { partici- } \\
\text { pants }\end{array}$ & Statistical method & Effect size \\
\hline 3 Bleeding (early) & 15 & 779 & $\begin{array}{l}\text { Risk Ratio (M-H, Fixed, 95\% } \\
\mathrm{Cl} \text { ) }\end{array}$ & $2.18[1.37,3.47]$ \\
\hline 4 Stroke/intracerebral haemorrhage (early) & 15 & 779 & $\begin{array}{l}\text { Risk Ratio (M-H, Fixed, 95\% } \\
\mathrm{Cl} \text { ) }\end{array}$ & $1.92[0.34,10.86]$ \\
\hline 5 Mortality (early) & 8 & 394 & $\begin{array}{l}\text { Risk Ratio (M-H, Fixed, 95\% } \\
\mathrm{Cl} \text { ) }\end{array}$ & $0.76[0.31,1.89]$ \\
\hline 6 Pulmonary embolism (early) & 5 & 298 & $\begin{array}{l}\text { Risk Ratio (M-H, Fixed, 95\% } \\
\mathrm{Cl} \text { ) }\end{array}$ & $1.73[0.55,5.40]$ \\
\hline 7 Post-thrombotic syndrome (intermediate) & 2 & 117 & $\begin{array}{l}\text { Risk Ratio (M-H, Random, } \\
95 \% \mathrm{Cl})\end{array}$ & $0.56[0.30,1.03]$ \\
\hline 8 Post-thrombotic syndrome (late) & 1 & & $\begin{array}{l}\text { Risk Ratio (M-H, Fixed, 95\% } \\
\mathrm{Cl} \text { ) }\end{array}$ & Totals not selected \\
\hline 9 Leg ulceration (intermediate) & 3 & 153 & $\begin{array}{l}\text { Risk Ratio (M-H, Fixed, 95\% } \\
\mathrm{Cl} \text { ) }\end{array}$ & $0.87[0.16,4.73]$ \\
\hline 10 Leg ulceration (late) & 1 & & $\begin{array}{l}\text { Risk Ratio (M-H, Fixed, 95\% } \\
\mathrm{Cl})\end{array}$ & Totals not selected \\
\hline 11 Complete clot lysis (intermediate) & 5 & 300 & $\begin{array}{l}\text { Risk Ratio (M-H, Random, } \\
95 \% \mathrm{Cl} \text { ) }\end{array}$ & $2.59[1.27,5.28]$ \\
\hline 12 Complete clot lysis (late) & 1 & & $\begin{array}{l}\text { Risk Ratio (M-H, Fixed, 95\% } \\
\mathrm{Cl} \text { ) }\end{array}$ & Totals not selected \\
\hline 13 Mortality (intermediate) & 2 & 189 & $\begin{array}{l}\text { Risk Ratio (M-H, Fixed, 95\% } \\
\mathrm{Cl} \text { ) }\end{array}$ & $0.96[0.27,3.43]$ \\
\hline 14 Mortality (late) & 1 & & $\begin{array}{l}\text { Risk Ratio (M-H, Fixed, 95\% } \\
\mathrm{Cl} \text { ) }\end{array}$ & Totals not selected \\
\hline 15 Normal venous function (intermediate) & 1 & & $\begin{array}{l}\text { Risk Ratio (M-H, Fixed, 95\% } \\
\mathrm{Cl} \text { ) }\end{array}$ & Totals not selected \\
\hline 16 Recurrent DVT (late) & 1 & & $\begin{array}{l}\text { Risk Ratio (M-H, Fixed, 95\% } \\
\mathrm{Cl} \text { ) }\end{array}$ & Totals not selected \\
\hline
\end{tabular}

Analysis 2.1. Comparison 2 Systemic thrombolysis versus control, Outcome 1 Any improvement in venous patency (early).

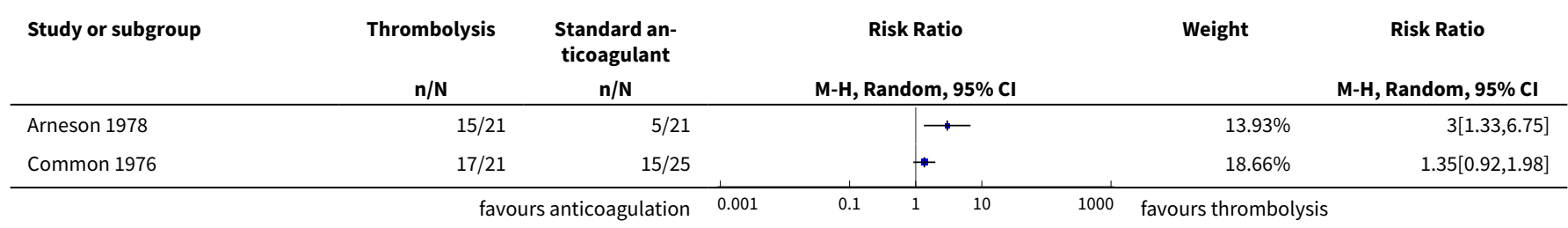




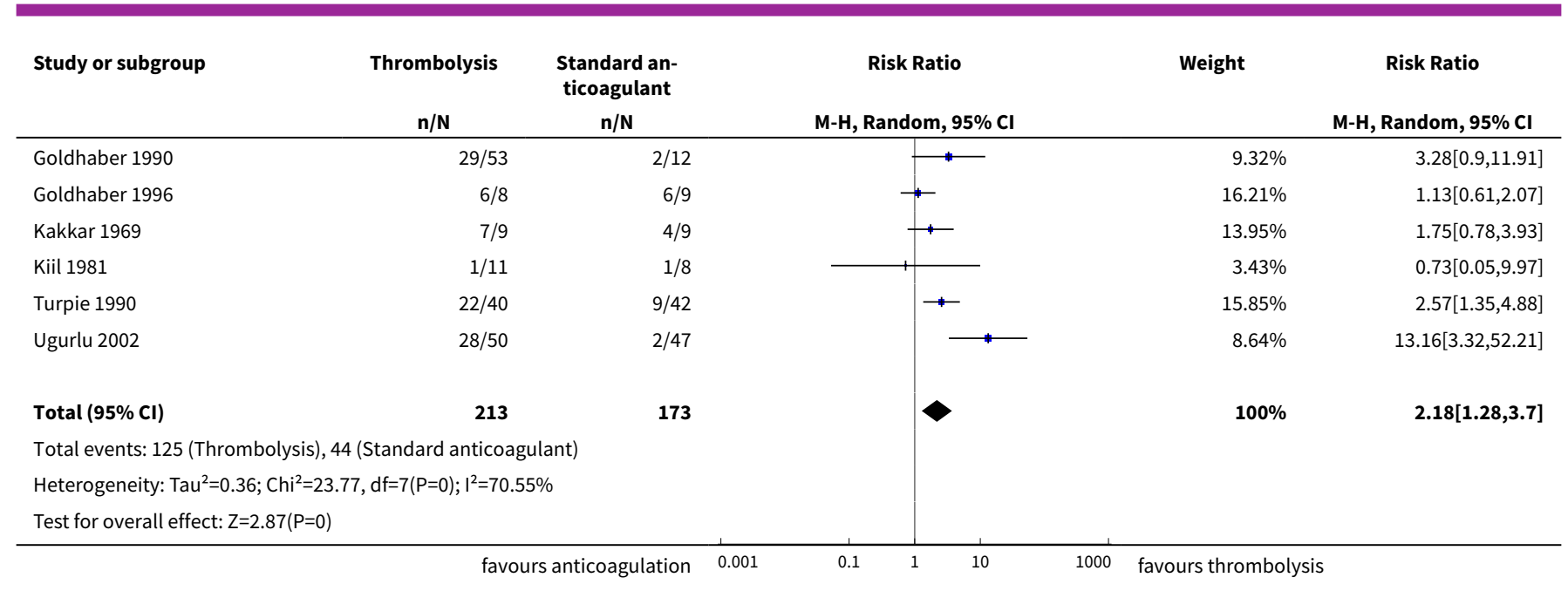

Analysis 2.2. Comparison 2 Systemic thrombolysis versus control, Outcome 2 Complete clot lysis (early).

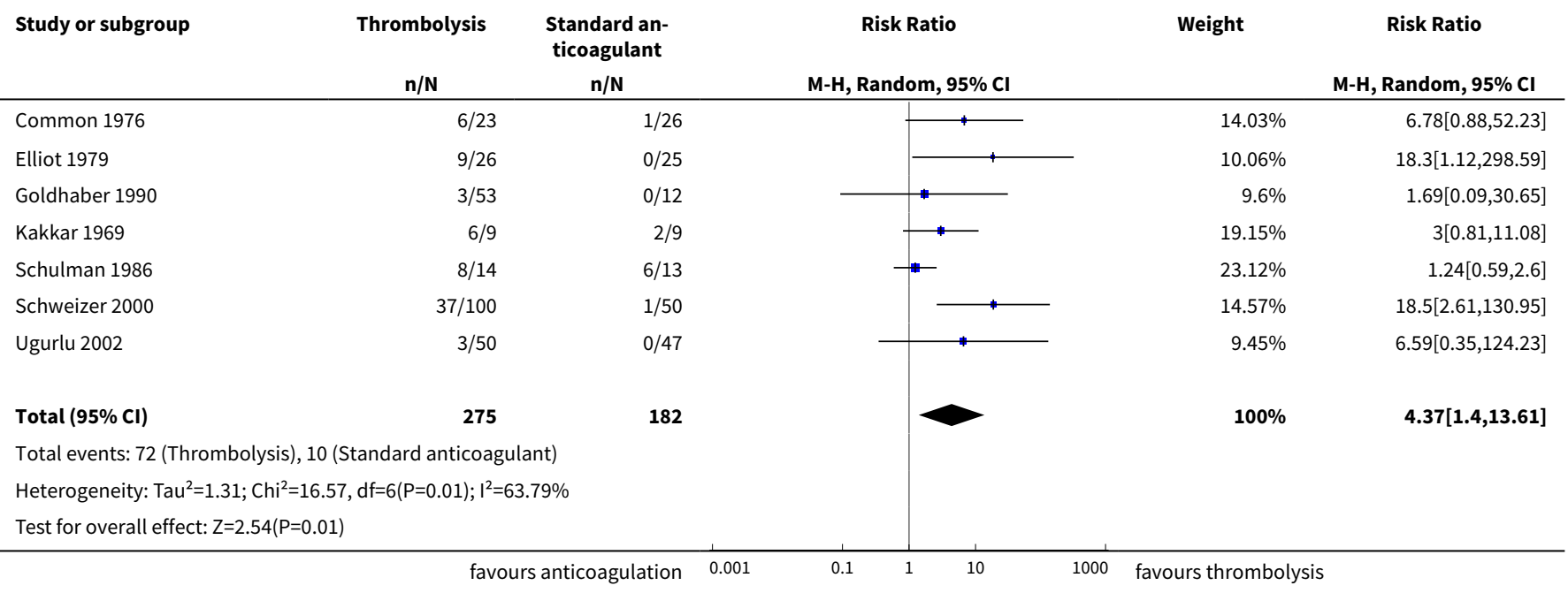

Analysis 2.3. Comparison 2 Systemic thrombolysis versus control, Outcome 3 Bleeding (early).

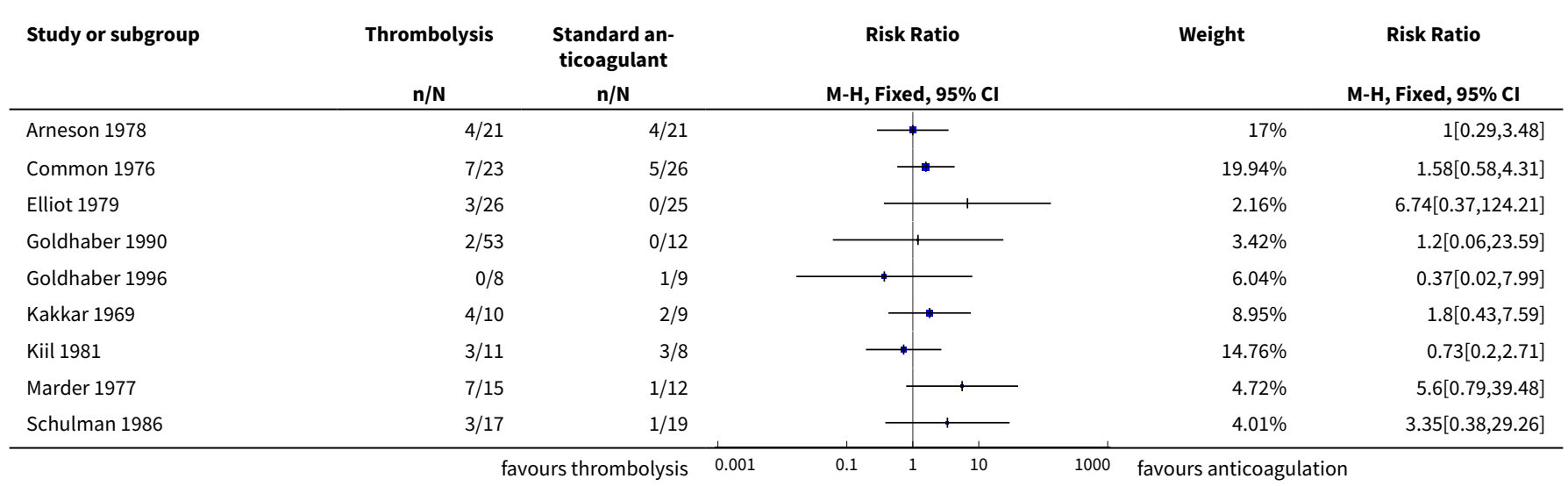




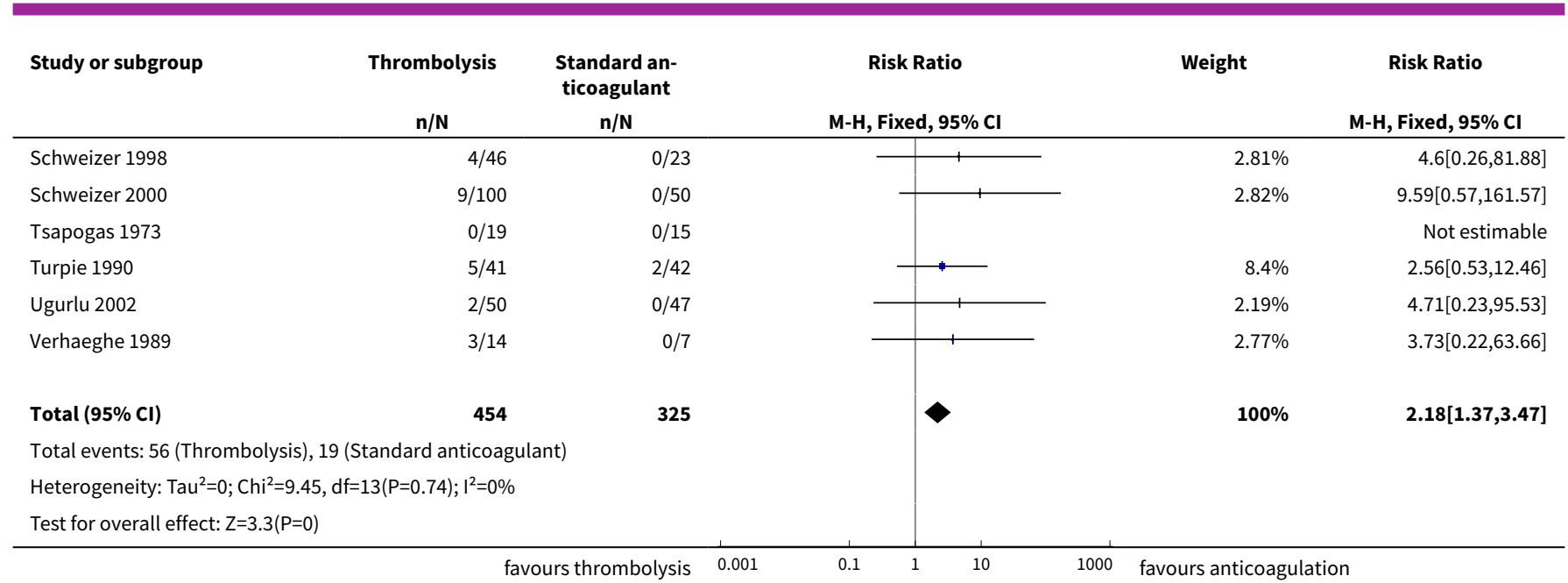

Analysis 2.4. Comparison 2 Systemic thrombolysis versus
control, Outcome 4 Stroke/intracerebral haemorrhage (early).

\begin{tabular}{|c|c|c|c|c|c|}
\hline \multirow[t]{2}{*}{ Study or subgroup } & Thrombolysis & $\begin{array}{l}\text { Standard an- } \\
\text { ticoagulant }\end{array}$ & Risk Ratio & \multirow[t]{2}{*}{ Weight } & \multirow{2}{*}{$\begin{array}{c}\text { Risk Ratio } \\
\text { M-H, Fixed, 95\% Cl }\end{array}$} \\
\hline & $n / N$ & $\mathrm{n} / \mathrm{N}$ & M-H, Fixed, $95 \% \mathrm{Cl}$ & & \\
\hline Arneson 1978 & $0 / 21$ & $0 / 21$ & & & Not estimable \\
\hline Common 1976 & $1 / 23$ & $0 / 26$ & & $25.74 \%$ & $3.38[0.14,79]$ \\
\hline Elliot 1979 & $0 / 26$ & $0 / 25$ & & & Not estimable \\
\hline Goldhaber 1990 & $1 / 53$ & $0 / 12$ & 口 & $44.08 \%$ & $0.72[0.03,16.73]$ \\
\hline Kakkar 1969 & $0 / 10$ & $0 / 9$ & & & Not estimable \\
\hline Kiil 1981 & $0 / 11$ & $0 / 8$ & & & Not estimable \\
\hline Marder 1977 & $1 / 15$ & $0 / 12$ & & $30.18 \%$ & $2.44[0.11,54.97]$ \\
\hline Schulman 1986 & $0 / 17$ & $0 / 19$ & & & Not estimable \\
\hline Schweizer 1998 & $0 / 46$ & $0 / 23$ & & & Not estimable \\
\hline Schweizer 2000 & $0 / 100$ & $0 / 50$ & & & Not estimable \\
\hline Turpie 1990 & $0 / 41$ & $0 / 42$ & & & Not estimable \\
\hline Ugurlu 2002 & $0 / 50$ & $0 / 47$ & & & Not estimable \\
\hline Verhaeghe 1989 & $0 / 14$ & $0 / 7$ & & & Not estimable \\
\hline Total $(95 \% \mathrm{CI})$ & 454 & 325 & & $100 \%$ & $1.92[0.34,10.86]$ \\
\hline \multicolumn{6}{|c|}{ Total events: 3 (Thrombolysis), 0 (Standard anticoagulant) } \\
\hline \multicolumn{6}{|c|}{ Heterogeneity: $\operatorname{Tau}^{2}=0 ; \mathrm{Chi}^{2}=0.52, \mathrm{df}=2(\mathrm{P}=0.77) ; \mathrm{I}^{2}=0 \%$} \\
\hline \multicolumn{6}{|c|}{ Test for overall effect: $Z=0.74(P=0.46)$} \\
\hline
\end{tabular}

Thrombolysis for acute deep vein thrombosis (Review) 
Analysis 2.5. Comparison 2 Systemic thrombolysis versus control, Outcome 5 Mortality (early).

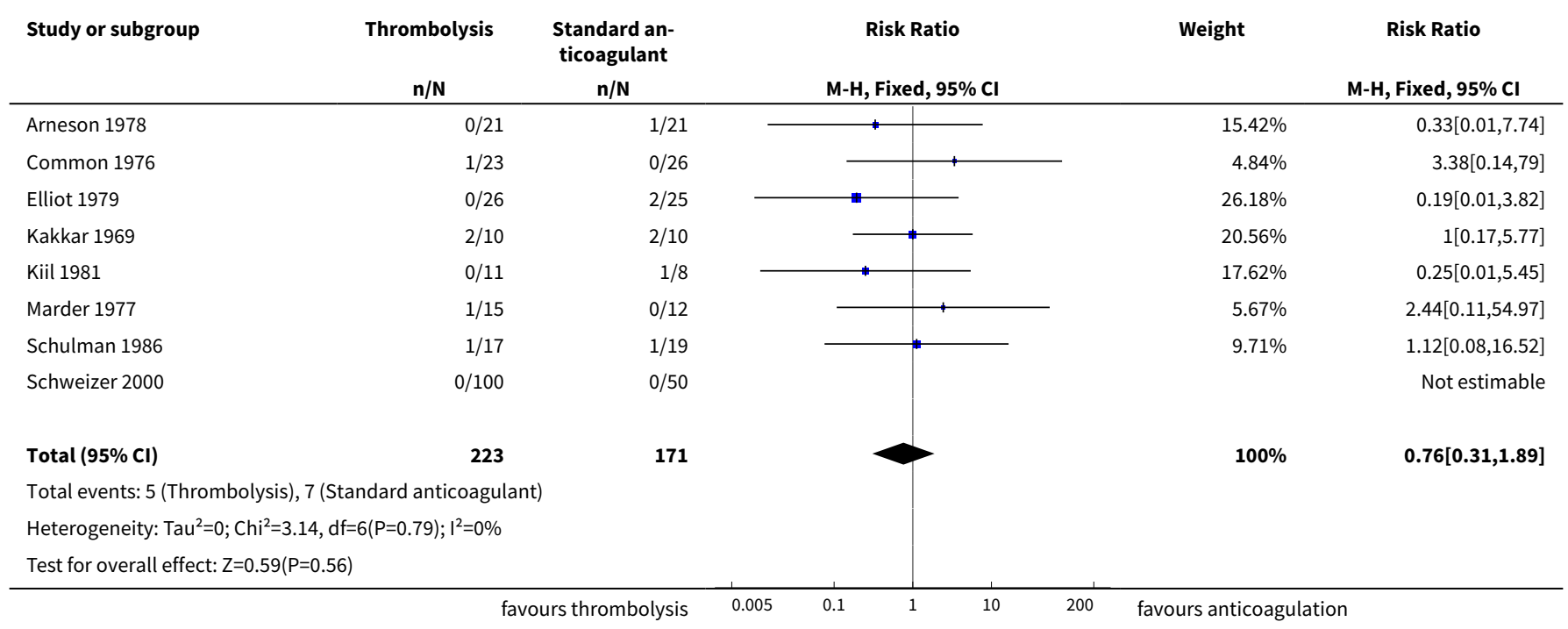

\section{Analysis 2.6. Comparison 2 Systemic thrombolysis versus control, Outcome 6 Pulmonary embolism (early).}

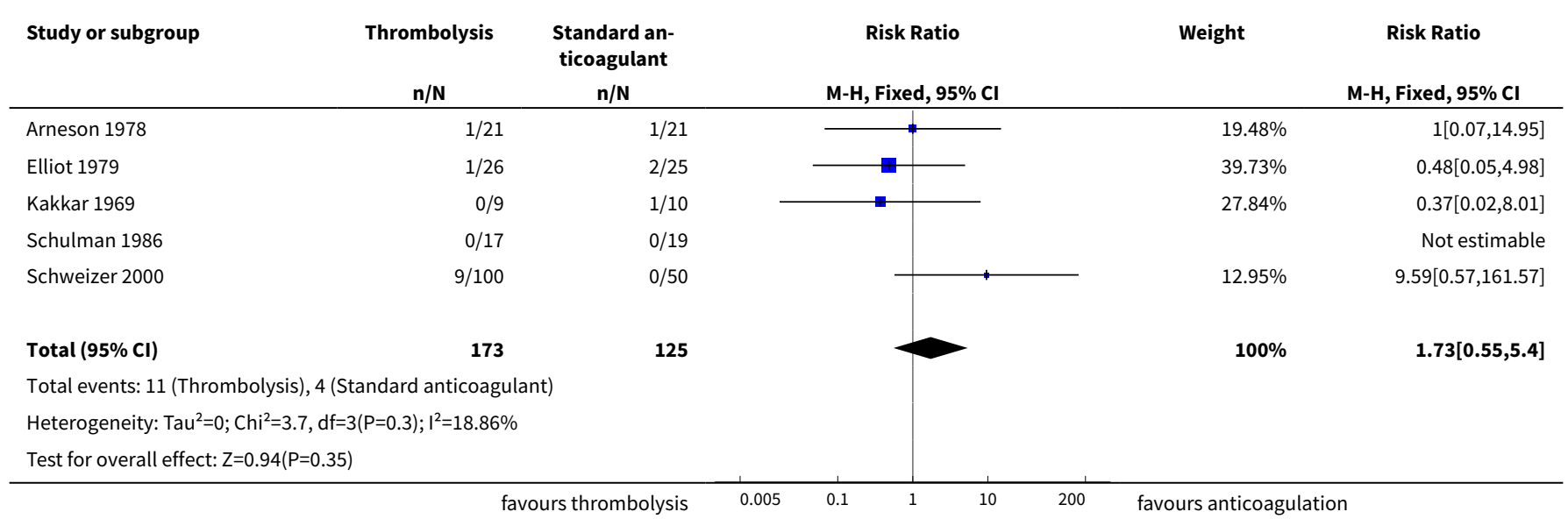

Analysis 2.7. Comparison 2 Systemic thrombolysis versus control, Outcome 7 Post-thrombotic syndrome (intermediate).

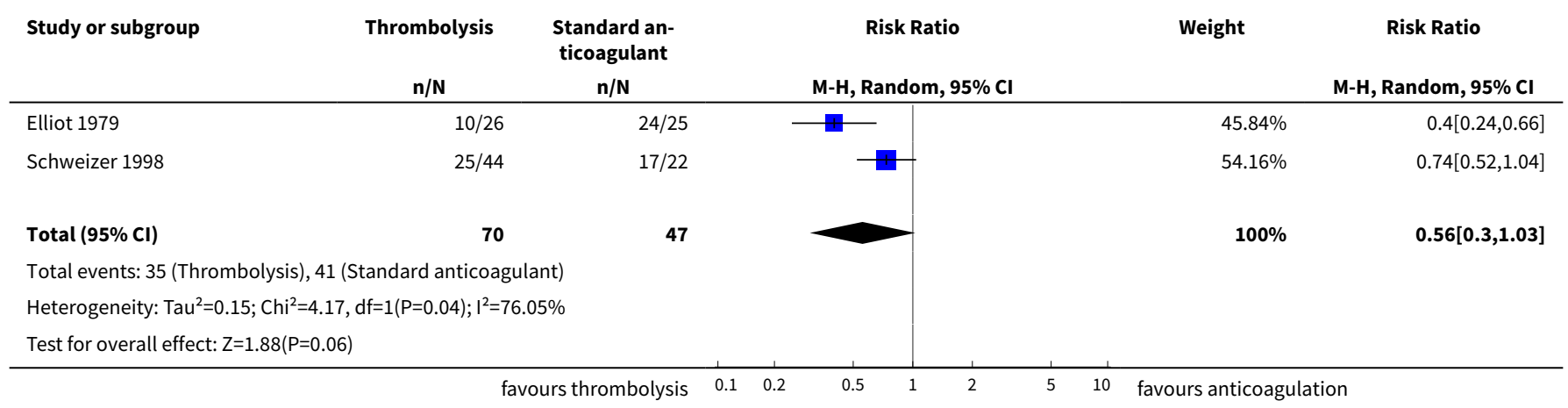


Analysis 2.8. Comparison 2 Systemic thrombolysis versus control, Outcome 8 Post-thrombotic syndrome (late).

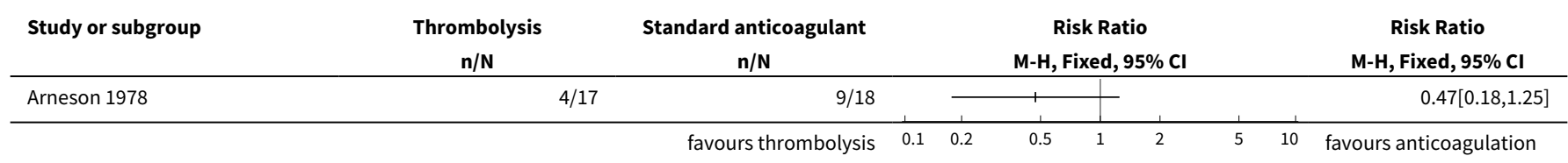

Analysis 2.9. Comparison 2 Systemic thrombolysis versus control, Outcome 9 Leg ulceration (intermediate).

\begin{tabular}{|c|c|c|c|c|c|}
\hline \multirow[t]{2}{*}{ Study or subgroup } & Thrombolysis & $\begin{array}{l}\text { Standard an- } \\
\text { ticoagulant }\end{array}$ & Risk Ratio & Weight & Risk Ratio \\
\hline & $\mathbf{n} / \mathbf{N}$ & $\mathrm{n} / \mathrm{N}$ & \multicolumn{2}{|l|}{ M-H, Fixed, 95\% Cl } & Fixed, $95 \% \mathrm{Cl}$ \\
\hline Elliot 1979 & $0 / 26$ & $1 / 25$ & $\rightarrow$ & $53.41 \%$ & $0.32[0.01,7.53]$ \\
\hline Schulman 1986 & $0 / 17$ & $0 / 19$ & & & Not estimable \\
\hline Schweizer 1998 & $3 / 44$ & $1 / 22$ & & $46.59 \%$ & $1.5[0.17,13.6]$ \\
\hline \multicolumn{6}{|c|}{ Total events: 3 (Thrombolysis), 2 (Standard anticoagulant) } \\
\hline \multicolumn{6}{|c|}{ Heterogeneity: $\operatorname{Tau}^{2}=0 ; \mathrm{Chi}^{2}=0.62, \mathrm{df}=1(\mathrm{P}=0.43) ; \mathrm{I}^{2}=0 \%$} \\
\hline \multicolumn{6}{|c|}{ Test for overall effect: $Z=0.16(P=0.87)$} \\
\hline
\end{tabular}

Analysis 2.10. Comparison 2 Systemic thrombolysis versus control, Outcome 10 Leg ulceration (late).

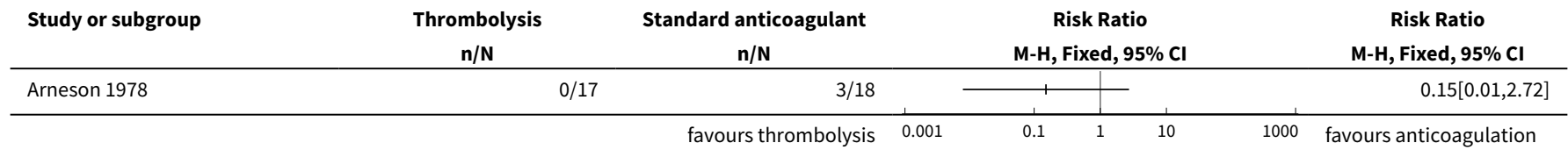

Analysis 2.11. Comparison 2 Systemic thrombolysis versus control, Outcome 11 Complete clot lysis (intermediate).

\begin{tabular}{|c|c|c|c|c|c|}
\hline \multirow[t]{2}{*}{ Study or subgroup } & Thrombolysis & $\begin{array}{c}\text { Standard an- } \\
\text { ticoagulant }\end{array}$ & Risk Ratio & Weight & \multirow{2}{*}{$\begin{array}{c}\text { Risk Ratio } \\
\text { M-H, Random, } 95 \% \mathrm{Cl}\end{array}$} \\
\hline & $\mathrm{n} / \mathrm{N}$ & $\mathrm{n} / \mathrm{N}$ & M-H, Random, $95 \% \mathrm{CI}$ & & \\
\hline Common 1976 & $6 / 15$ & $1 / 12$ & $\longrightarrow$ & $9.72 \%$ & $4.8[0.67,34.63]$ \\
\hline Elliot 1979 & $12 / 26$ & $0 / 25$ & $\longrightarrow$ & $5.62 \%$ & $24.07[1.5,386.09]$ \\
\hline Schulman 1986 & $11 / 15$ & $6 / 12$ & $=$ & $29.49 \%$ & $1.47[0.77,2.79]$ \\
\hline Schweizer 1998 & $27 / 44$ & $8 / 22$ & - & $30.43 \%$ & $1.69[0.93,3.08]$ \\
\hline Total $(95 \% \mathrm{Cl})$ & 183 & 117 & & $100 \%$ & $2.59[1.27,5.28]$ \\
\hline \multicolumn{6}{|c|}{ Total events: 93 (Thrombolysis), 20 (Standard anticoagulant) } \\
\hline \multicolumn{6}{|c|}{ Heterogeneity: $\mathrm{Tau}^{2}=0.34 ; \mathrm{Chi}^{2}=10.12, \mathrm{df}=4(\mathrm{P}=0.04) ; \mathrm{I}^{2}=60.47 \%$} \\
\hline \multicolumn{6}{|c|}{ Test for overall effect: $Z=2.62(P=0.01)$} \\
\hline
\end{tabular}


Analysis 2.12. Comparison 2 Systemic thrombolysis versus control, Outcome 12 Complete clot lysis (late).

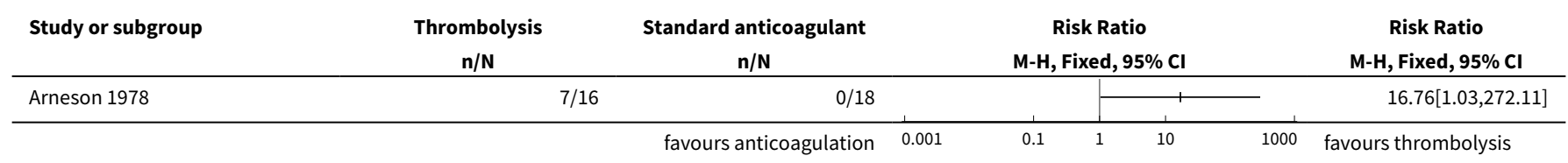

Analysis 2.13. Comparison 2 Systemic thrombolysis versus control, Outcome 13 Mortality (intermediate).

\begin{tabular}{|c|c|c|c|c|c|}
\hline \multirow[t]{2}{*}{ Study or subgroup } & Thrombolysis & $\begin{array}{l}\text { Standard an- } \\
\text { ticoagulant }\end{array}$ & Risk Ratio & Weight & Risk Ratio \\
\hline & $n / N$ & $n / N$ & M-H, Fixed, 95\% Cl & \multicolumn{2}{|c|}{ M-H, Fixed, 95\% Cl } \\
\hline Elliot 1979 & $4 / 26$ & $4 / 25$ & 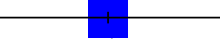 & \multirow[t]{2}{*}{$100 \%$} & $0.96[0.27,3.43]$ \\
\hline Schweizer 2000 & $0 / 92$ & $0 / 46$ & & & Not estimable \\
\hline Total $(95 \% \mathrm{Cl})$ & 118 & 71 & & \multirow[t]{3}{*}{$100 \%$} & \multirow[t]{3}{*}{$0.96[0.27,3.43]$} \\
\hline Heterogeneity: Not a & & & & & \\
\hline Test for overall effect & & & & & \\
\hline
\end{tabular}

Analysis 2.14. Comparison 2 Systemic thrombolysis versus control, Outcome 14 Mortality (late).

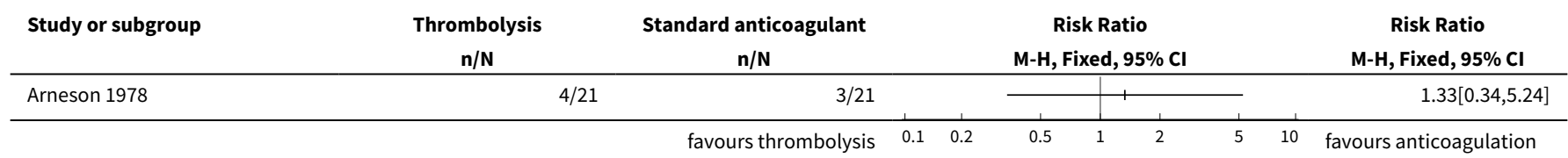

Analysis 2.15. Comparison 2 Systemic thrombolysis versus control, Outcome 15 Normal venous function (intermediate).

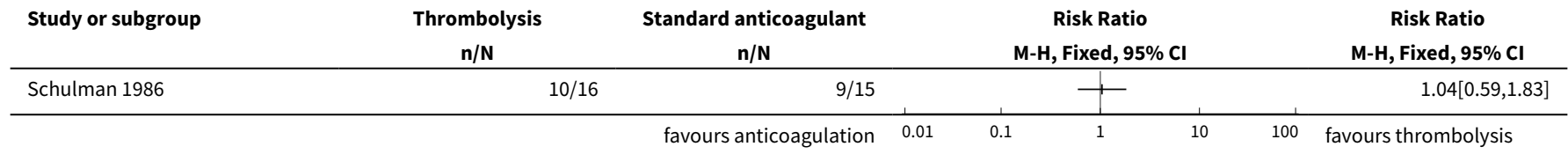

Analysis 2.16. Comparison 2 Systemic thrombolysis versus control, Outcome 16 Recurrent DVT (late).

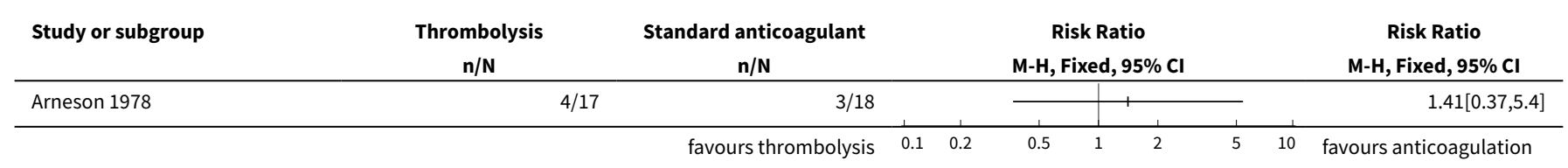


Comparison 3. Loco-regional thrombolysis versus control

\begin{tabular}{|c|c|c|c|c|}
\hline Outcome or subgroup title & $\begin{array}{l}\text { No. of } \\
\text { studies }\end{array}$ & $\begin{array}{l}\text { No. of } \\
\text { partici- } \\
\text { pants }\end{array}$ & Statistical method & Effect size \\
\hline 1 Complete clot lysis (early) & 1 & & Risk Ratio (M-H, Fixed, 95\% Cl) & Totals not selected \\
\hline 2 Bleeding (early) & 2 & 146 & Risk Ratio (M-H, Fixed, 95\% Cl) & $4.0[0.46,34.75]$ \\
\hline $\begin{array}{l}3 \text { Stroke/intracerebral haemorrhage } \\
\text { (early) }\end{array}$ & 2 & 146 & Risk Ratio (M-H, Fixed, 95\% Cl) & $0.0[0.0,0.0]$ \\
\hline 4 Mortality (early) & 1 & & Risk Ratio (M-H, Fixed, 95\% Cl) & Totals not selected \\
\hline 5 Pulmonary embolism (early) & 1 & & Risk Ratio (M-H, Fixed, 95\% Cl) & Totals not selected \\
\hline $\begin{array}{l}6 \text { Post-thrombotic syndrome (inter- } \\
\text { mediate) }\end{array}$ & 1 & & Risk Ratio (M-H, Fixed, 95\% Cl) & Totals not selected \\
\hline 7 Leg ulceration (intermediate) & 1 & & Risk Ratio (M-H, Fixed, 95\% Cl) & Totals not selected \\
\hline 8 Complete clot lysis (intermediate) & 2 & 139 & Risk Ratio (M-H, Fixed, 95\% Cl) & $2.25[1.33,3.80]$ \\
\hline 9 Mortality (intermediate) & 1 & & Risk Ratio (M-H, Fixed, 95\% Cl) & Totals not selected \\
\hline
\end{tabular}

Analysis 3.1. Comparison 3 Loco-regional thrombolysis versus control, Outcome 1 Complete clot lysis (early).

\begin{tabular}{|c|c|c|c|c|c|c|c|}
\hline \multirow{2}{*}{$\begin{array}{l}\text { Study or subgroup } \\
\text { Schweizer } 2000\end{array}$} & $\begin{array}{c}\text { Thrombolysis } \\
\mathrm{n} / \mathrm{N} \\
\end{array}$ & $\begin{array}{c}\text { Standard anticoagulant } \\
\mathrm{n} / \mathrm{N} \\
\end{array}$ & & \multicolumn{2}{|c|}{$\begin{array}{c}\text { Risk Ratio } \\
\text { M-H, Fixed, } 95 \% \mathrm{Cl} \\
\end{array}$} & & \multirow{2}{*}{$\begin{array}{c}\begin{array}{c}\text { Risk Ratio } \\
\text { M-H, Fixed, 95\% Cl }\end{array} \\
10[1.33,75.23\end{array}$} \\
\hline & $10 / 50$ & $1 / 50$ & & & 1 & & \\
\hline
\end{tabular}

Analysis 3.2. Comparison 3 Loco-regional thrombolysis versus control, Outcome 2 Bleeding (early).

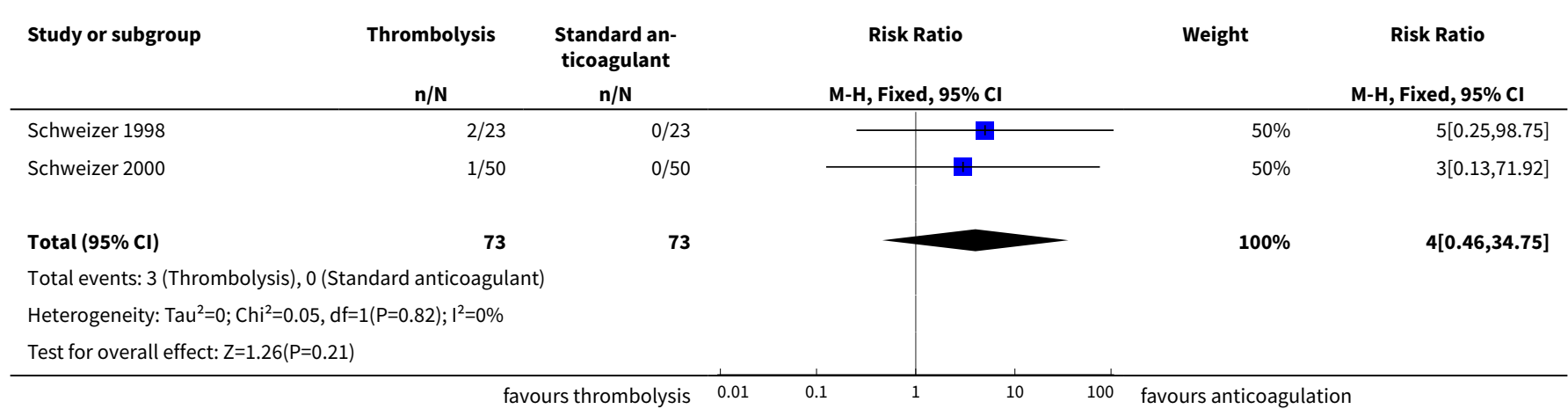


Analysis 3.3. Comparison 3 Loco-regional thrombolysis versus control, Outcome 3 Stroke/intracerebral haemorrhage (early).

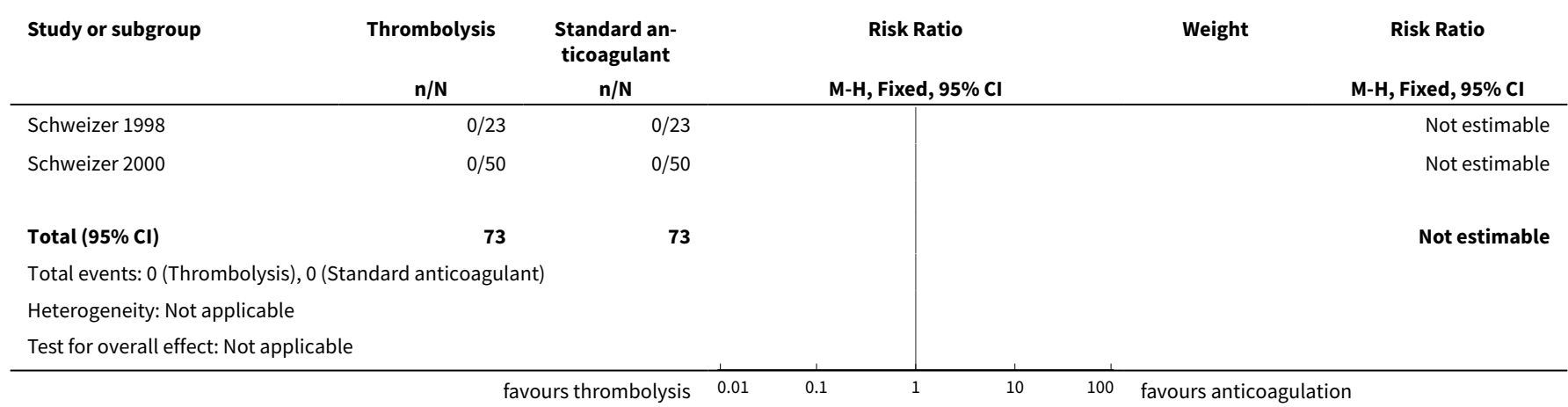

Analysis 3.4. Comparison 3 Loco-regional thrombolysis versus control, Outcome 4 Mortality (early).

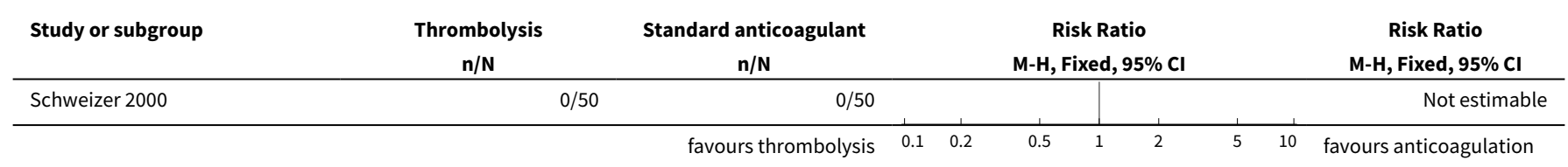

Analysis 3.5. Comparison 3 Loco-regional thrombolysis versus control, Outcome 5 Pulmonary embolism (early).

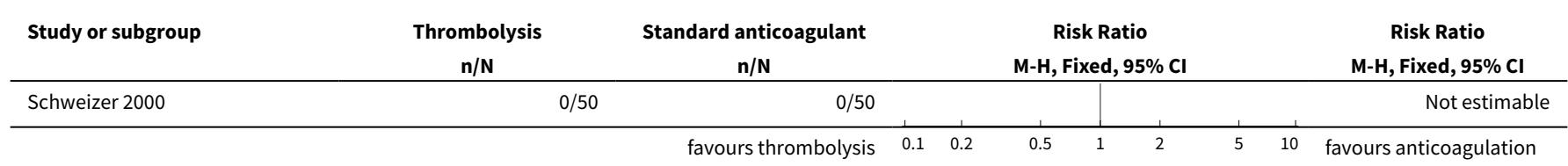

Analysis 3.6. Comparison 3 Loco-regional thrombolysis versus control, Outcome 6 Post-thrombotic syndrome (intermediate).

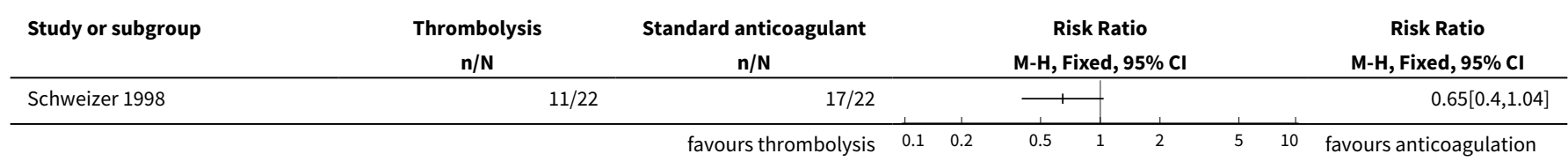

Analysis 3.7. Comparison 3 Loco-regional thrombolysis versus control, Outcome 7 Leg ulceration (intermediate).

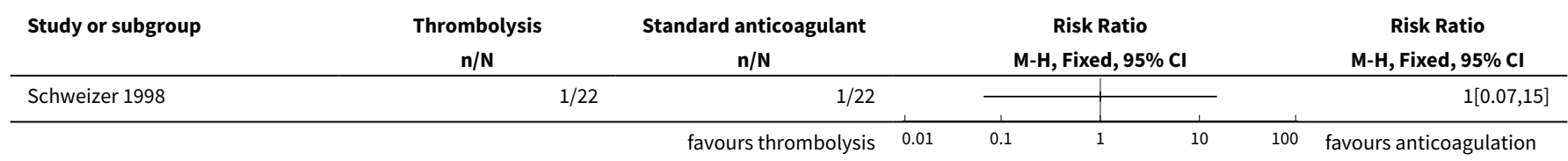


Analysis 3.8. Comparison 3 Loco-regional thrombolysis versus control, Outcome 8 Complete clot lysis (intermediate).

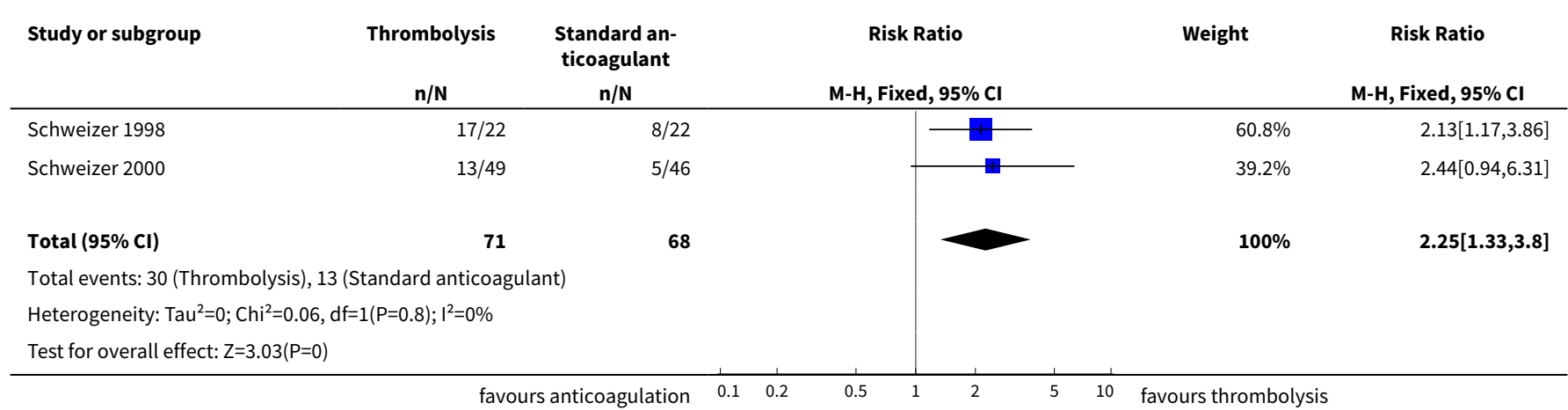

Analysis 3.9. Comparison 3 Loco-regional thrombolysis versus control, Outcome 9 Mortality (intermediate).

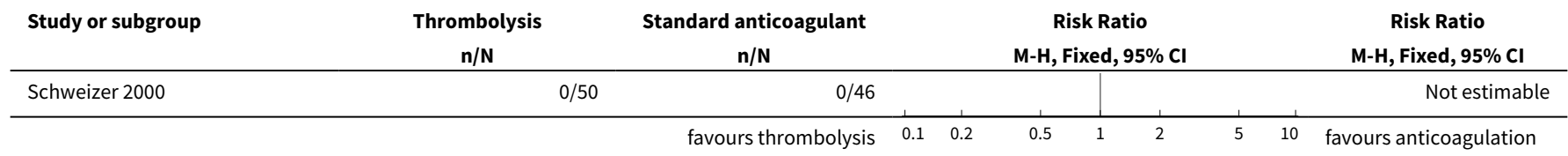

\section{Comparison 4. Catheter-directed thrombolysis versus control}

\begin{tabular}{|c|c|c|c|c|}
\hline Outcome or subgroup title & $\begin{array}{l}\text { No. of } \\
\text { studies }\end{array}$ & $\begin{array}{l}\text { No. of } \\
\text { partici- } \\
\text { pants }\end{array}$ & Statistical method & Effect size \\
\hline $\begin{array}{l}1 \text { Any improvement in venous pa- } \\
\text { tency (early) }\end{array}$ & 1 & & Risk Ratio (M-H, Fixed, 95\% Cl) & Totals not selected \\
\hline 2 Complete clot lysis (early) & 1 & & Risk Ratio (M-H, Fixed, 95\% Cl) & Totals not selected \\
\hline 3 Bleeding (early) & 2 & 224 & Risk Ratio (M-H, Fixed, 95\% Cl) & $7.69[0.40,146.90]$ \\
\hline $\begin{array}{l}4 \text { Stroke/intracerebral haemorrhage } \\
\text { (early) }\end{array}$ & 1 & & Risk Ratio (M-H, Fixed, 95\% Cl) & Totals not selected \\
\hline 5 Mortality (early) & 1 & & Risk Ratio (M-H, Fixed, 95\% Cl) & Totals not selected \\
\hline 6 Pulmonary embolism (early) & 1 & & Risk Ratio (M-H, Fixed, 95\% Cl) & Totals not selected \\
\hline $\begin{array}{l}7 \text { Post-thrombotic syndrome (inter- } \\
\text { mediate) }\end{array}$ & 1 & & Risk Ratio (M-H, Fixed, 95\% Cl) & Totals not selected \\
\hline 8 Post-thrombotic syndrome (late) & 1 & & Risk Ratio (M-H, Fixed, 95\% Cl) & Totals not selected \\
\hline 9 Leg ulceration (intermediate) & 1 & & Risk Ratio (M-H, Fixed, 95\% Cl) & Totals not selected \\
\hline $\begin{array}{l}10 \text { Complete clot lysis (intermedi- } \\
\text { ate) }\end{array}$ & 2 & 224 & Risk Ratio (M-H, Random, 95\% Cl) & $2.52[0.52,12.17]$ \\
\hline
\end{tabular}




\begin{tabular}{lllll}
\hline Outcome or subgroup title & $\begin{array}{l}\text { No. of } \\
\text { studies }\end{array}$ & $\begin{array}{l}\text { No. of } \\
\text { partici- } \\
\text { pants }\end{array}$ & Statistical method & Effect size \\
\hline 11 Complete clot lysis (late) & 1 & & Risk Ratio (M-H, Fixed, 95\% Cl) & Totals not selected \\
\hline $\begin{array}{l}12 \text { Normal venous function (inter- } \\
\text { mediate) }\end{array}$ & 2 & 224 & Risk Ratio (M-H, Fixed, 95\% Cl) & $2.98[1.75,5.08]$ \\
\hline 13 Recurrent VTE (intermediate) & 1 & Risk Ratio (M-H, Fixed, 95\% Cl) & Totals not selected \\
\hline 14 Recurrent VTE (late) & 1 & Risk Ratio (M-H, Fixed, 95\% Cl) & Totals not selected \\
\hline 15 Mortality (late) & 1 & Risk Ratio (M-H, Fixed, 95\% Cl) & Totals not selected \\
\hline
\end{tabular}

Analysis 4.1. Comparison 4 Catheter-directed thrombolysis versus control, Outcome 1 Any improvement in venous patency (early).

\begin{tabular}{|c|c|c|c|c|c|c|c|}
\hline & $\begin{array}{c}\text { Thrombolysis } \\
\mathrm{n} / \mathrm{N}\end{array}$ & $\begin{array}{c}\text { Standard anticoagulant } \\
n / N\end{array}$ & & \multicolumn{2}{|c|}{$\begin{array}{c}\text { Risk Ratio } \\
\text { M-H, Fixed, 95\% Cl }\end{array}$} & & \multirow{2}{*}{$\begin{array}{c}\text { Risk Ratio } \\
\text { M-H, Fixed, 95\% Cl } \\
35.05[2.28,539.63\end{array}$} \\
\hline Elsharawy 2002 & $18 / 18$ & $0 / 17$ & & & $\longrightarrow$ & & \\
\hline
\end{tabular}

Analysis 4.2. Comparison 4 Catheter-directed thrombolysis versus control, Outcome 2 Complete clot lysis (early).

\begin{tabular}{|c|c|c|c|c|c|c|}
\hline \multirow{2}{*}{$\begin{array}{l}\text { Study or subgroup } \\
\text { Elsharawy } 2002\end{array}$} & $\begin{array}{c}\text { Thrombolysis } \\
\mathrm{n} / \mathrm{N} \\
\end{array}$ & $\begin{array}{c}\text { Standard anticoagulant } \\
n / N\end{array}$ & \multicolumn{3}{|c|}{$\begin{array}{c}\text { Risk Ratio } \\
\text { M-H, Fixed, 95\% Cl }\end{array}$} & \multirow{2}{*}{$\begin{array}{c}\text { Risk Ratio } \\
\text { M-H, Fixed, } \mathbf{9 5 \%} \mathbf{~ C l} \\
21.79[1.38,343.26]\end{array}$} \\
\hline & $11 / 18$ & $0 / 17$ & & & 1 & \\
\hline
\end{tabular}

Analysis 4.3. Comparison 4 Catheter-directed thrombolysis versus control, Outcome 3 Bleeding (early).

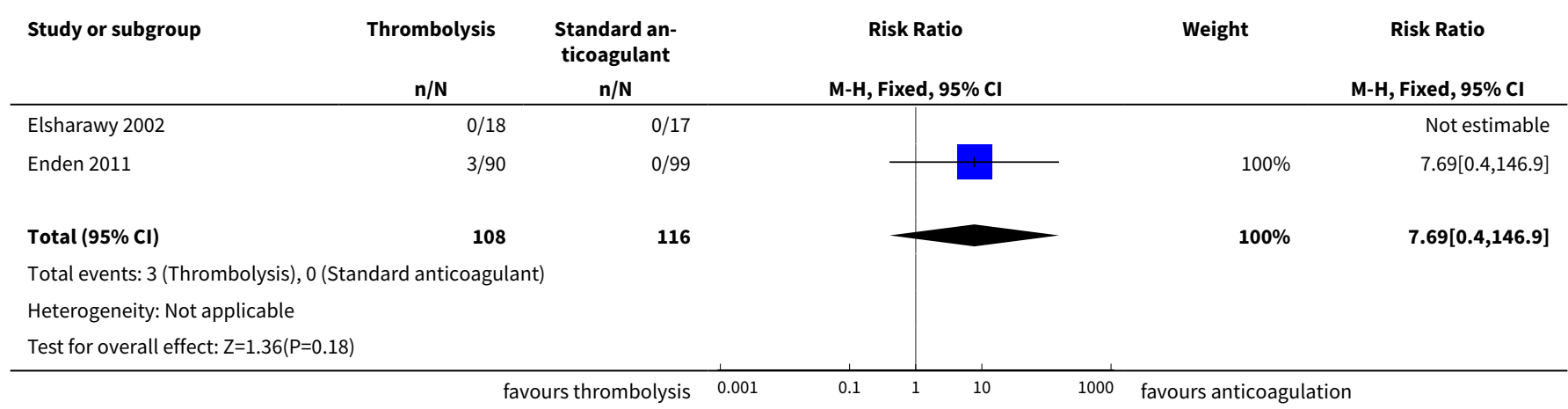


Analysis 4.4. Comparison 4 Catheter-directed thrombolysis versus control, Outcome 4 Stroke/intracerebral haemorrhage (early).

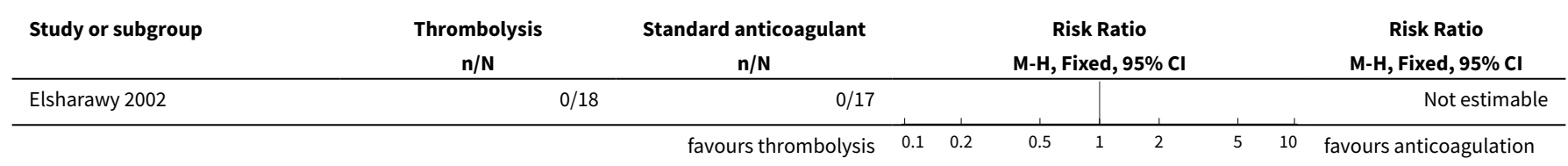

Analysis 4.5. Comparison 4 Catheter-directed thrombolysis versus control, Outcome 5 Mortality (early).

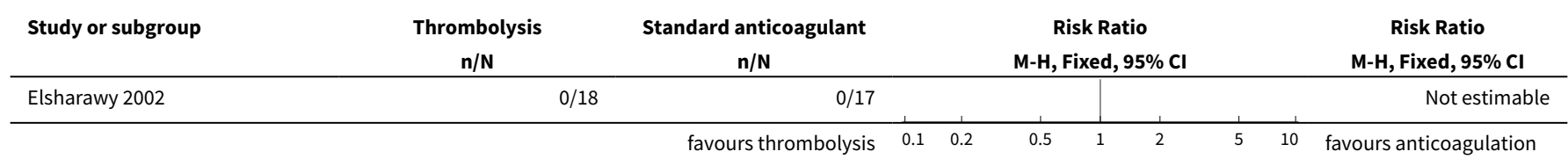

Analysis 4.6. Comparison 4 Catheter-directed thrombolysis versus control, Outcome 6 Pulmonary embolism (early).

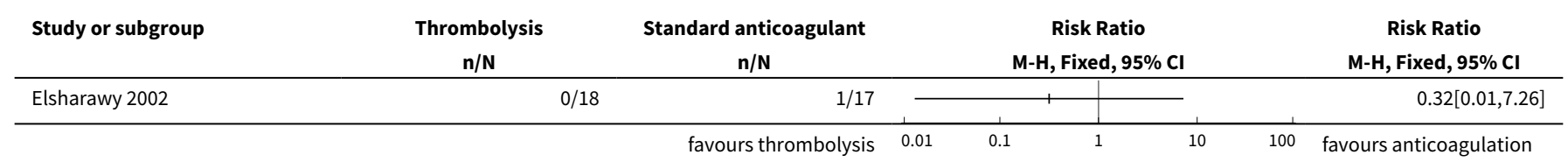

Analysis 4.7. Comparison 4 Catheter-directed thrombolysis versus control, Outcome 7 Post-thrombotic syndrome (intermediate).

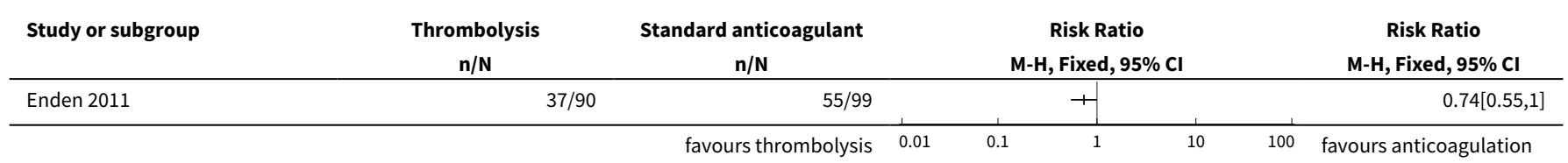

Analysis 4.8. Comparison 4 Catheter-directed thrombolysis versus control, Outcome 8 Post-thrombotic syndrome (late).

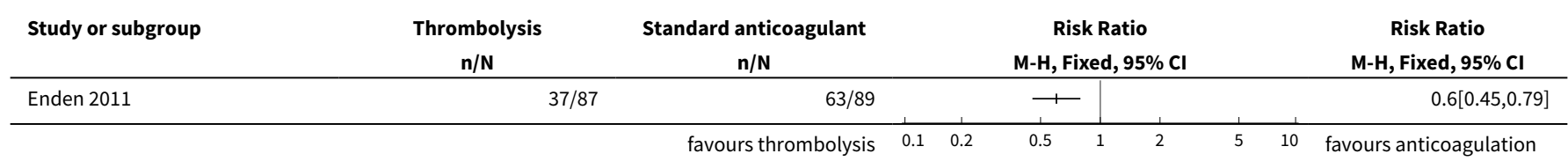


Analysis 4.9. Comparison 4 Catheter-directed thrombolysis versus control, Outcome 9 Leg ulceration (intermediate).

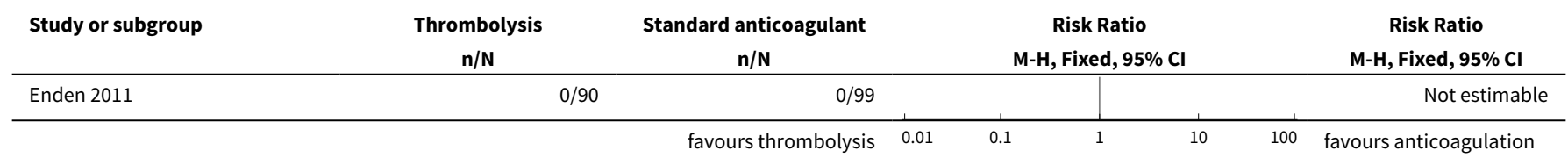

Analysis 4.10. Comparison 4 Catheter-directed thrombolysis versus control, Outcome 10 Complete clot lysis (intermediate).

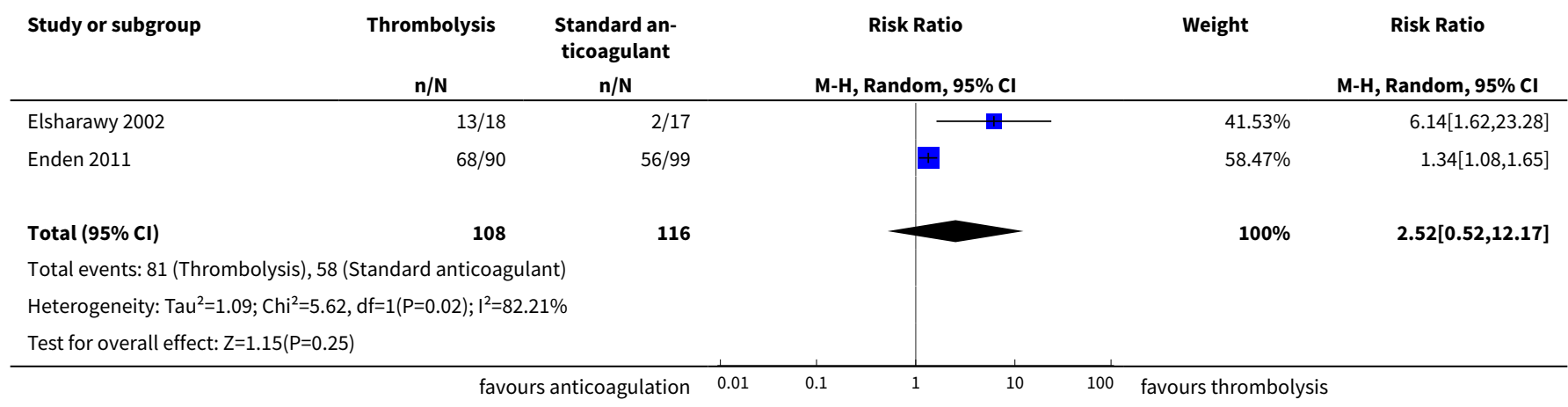

Analysis 4.11. Comparison 4 Catheter-directed thrombolysis versus control, Outcome 11 Complete clot lysis (late).

\begin{tabular}{|c|c|c|c|c|c|c|c|}
\hline Study or subgroup & $\begin{array}{c}\text { Thrombolysis } \\
\mathrm{n} / \mathrm{N}\end{array}$ & $\begin{array}{c}\text { Standard anticoagulant } \\
\mathrm{n} / \mathrm{N}\end{array}$ & & M-H, & & & $\begin{array}{c}\text { Risk Ratio } \\
\text { M-H, Fixed, 95\% Cl }\end{array}$ \\
\hline Enden 2011 & $68 / 86$ & $61 / 86$ & & & & & $1.11[0.94,1.33]$ \\
\hline
\end{tabular}

Analysis 4.12. Comparison 4 Catheter-directed thrombolysis versus control, Outcome 12 Normal venous function (intermediate).

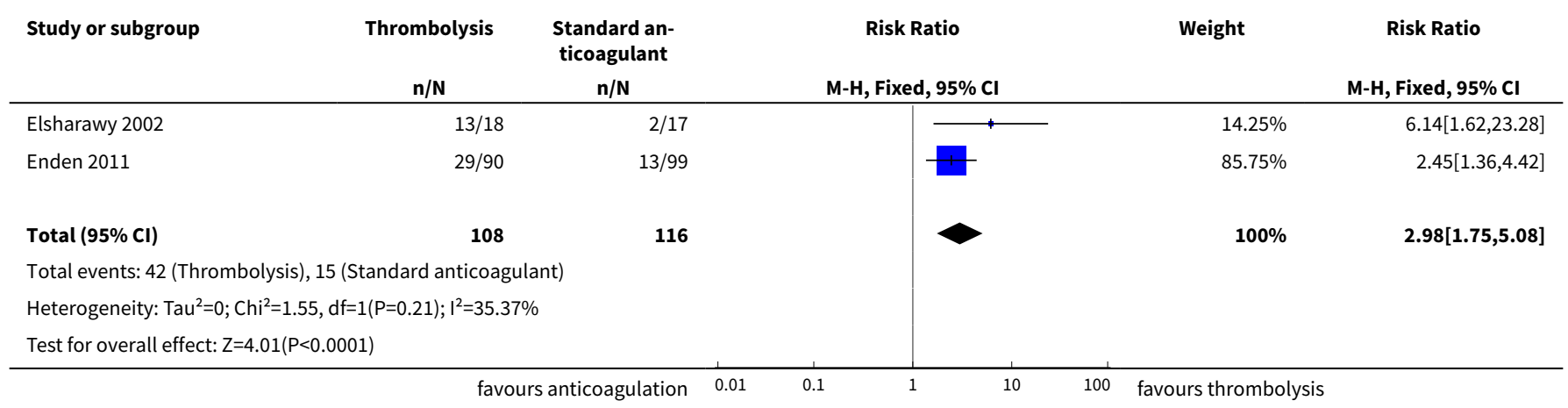


Analysis 4.13. Comparison 4 Catheter-directed thrombolysis versus control, Outcome 13 Recurrent VTE (intermediate).

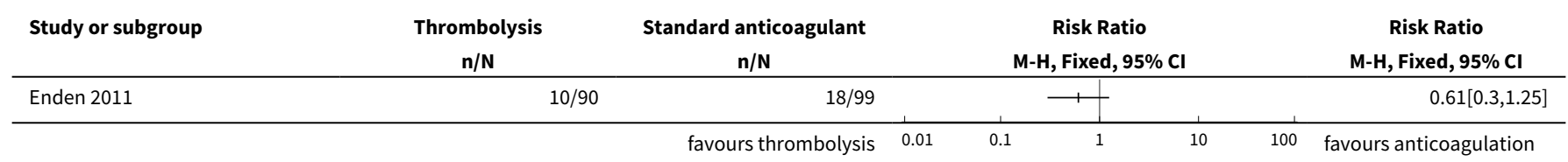

Analysis 4.14. Comparison 4 Catheter-directed thrombolysis versus control, Outcome 14 Recurrent VTE (late).

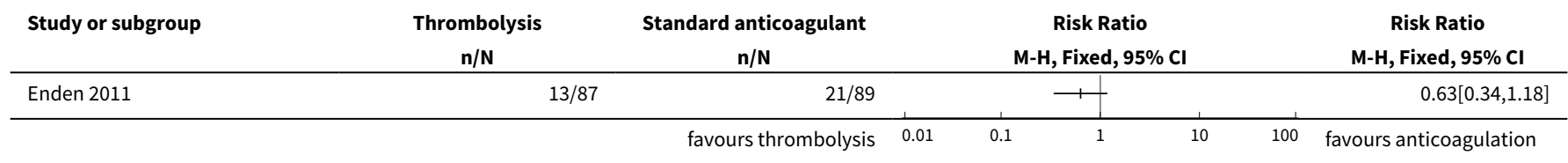

Analysis 4.15. Comparison 4 Catheter-directed thrombolysis versus control, Outcome 15 Mortality (late).

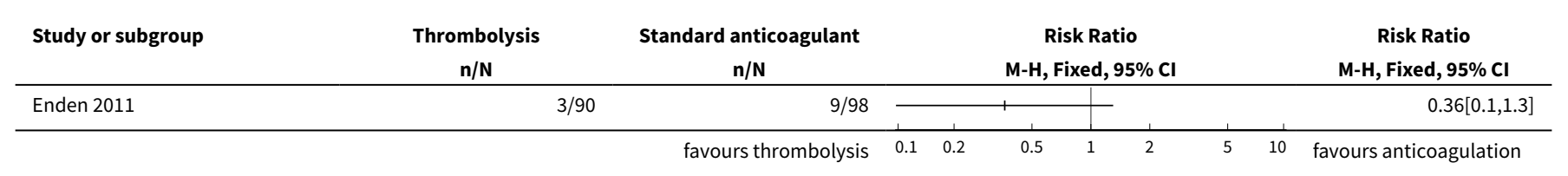

\section{ADDITIONAL TABLES}

Table 1. Level of affected leg veins in included studies

\begin{tabular}{ll}
\hline Study & Potential levels of leg vein included \\
\hline Arneson 1978 & proximal to calf \\
\hline Common 1976 & not specified \\
\hline Elliot 1979 & proximal \\
\hline Elsharawy 2002 & femoral and iliofemoral \\
\hline Enden 2011 & pelvic, iliofemoral, femoral \\
\hline Goldhaber 1990 & popliteal or more proximal \\
\hline Goldhaber 1996 & proximal \\
\hline Kakkar 1969 & not specified \\
\hline Kiil 1981 & not specified \\
\hline Marder 1977 & calf up to iliac vein \\
\hline
\end{tabular}


Table 1. Level of affected leg veins in included studies (Continued)

\begin{tabular}{ll} 
Schulman 1986 & calf vein thrombosis only \\
\hline Schweizer 1998 & not specified \\
\hline Schweizer 2000 & popliteal or more proximal \\
\hline Tsapogas 1973 & not specified \\
\hline Turpie 1990 & proximal \\
\hline Ugurlu 2002 & popliteal up to inferior vena cava \\
\hline Verhaeghe 1989 & popliteal or more proximal \\
\hline
\end{tabular}

\section{APPENDICES}

\section{Appendix 1. CENTRAL search strategy}

\begin{tabular}{|c|c|c|}
\hline$\# 1$ & MESH DESCRIPTOR Thrombosis & 1211 \\
\hline \#2 & MESH DESCRIPTOR Thromboembolism & 880 \\
\hline \#3 & MESH DESCRIPTOR Venous Thromboembolism & 221 \\
\hline \#4 & MESH DESCRIPTOR Venous Thrombosis EXPLODE ALL TREES & 1979 \\
\hline \#5 & $\begin{array}{l}\text { (thrombus* or thrombopro* or thrombotic* or thrombolic }{ }^{*} \text { or thromboemboli* or throm- } \\
\text { bos* }^{*} \text { or embol*):TI,AB,KY }\end{array}$ & 16407 \\
\hline \#6 & MESH DESCRIPTOR Pulmonary Embolism EXPLODE ALL TREES & 719 \\
\hline \#7 & (PE or DVT or VTE):TI,AB,KY & 4294 \\
\hline \#8 & $\left(\left(\right.\right.$ vein $^{\star}$ or ven $\left.^{\star}\right)$ near thromb*):TI,AB,KY & 5939 \\
\hline \#9 & (blood near3 clot*):TI,AB,KY & 2358 \\
\hline$\# 10$ & (pulmonary near3 clot ${ }^{\star}$ ):TI,AB,KY & 5 \\
\hline$\# 11$ & (lung near3 clot $\left.{ }^{\star}\right): \mathrm{TI}, \mathrm{AB}, \mathrm{KY}$ & 4 \\
\hline$\# 12$ & \#1 OR \#2 OR \#3 OR \#4 OR \#5 OR \#6 OR \#7 OR \#8 OR \#9 OR \#10 OR \#11 & 21211 \\
\hline \#13 & MESH DESCRIPTOR Thrombolytic Therapy EXPLODE ALL TREES & 1512 \\
\hline \#14 & MESH DESCRIPTOR Fibrinolytic Agents EXPLODE ALL TREES & 10655 \\
\hline$\# 15$ & MESH DESCRIPTOR Fibrinolysis EXPLODE ALL TREES & 930 \\
\hline$\# 16$ & MESH DESCRIPTOR Plasminogen Activators EXPLODE ALL TREES & 2193 \\
\hline
\end{tabular}


(Continued)

\begin{tabular}{|c|c|c|}
\hline \#17 & (plasminogen near2 activator ${ }^{\star}$ ):TI,AB, KY & 3444 \\
\hline \#18 & (tPA or t-PA or rtPA or rt-PA):TI,AB,KY & 1961 \\
\hline \#19 & (thromboly ${ }^{\star}$ or fibrinoly ${ }^{\star}$ or antithrombotic or antithrombic):TI,AB,KY & 8330 \\
\hline \#20 & (recanalis* or recanaliz*):TI,AB,KY & 836 \\
\hline \#21 & (((clot* or thrombus) near3 (lyse or lysis or dissolve* or dissolution $))): \mathrm{TI}, \mathrm{AB}, \mathrm{KY}$ & 663 \\
\hline \#22 & urokinase:TI,AB,KY & 774 \\
\hline \#23 & alteplase :TI,AB,KY & 601 \\
\hline \#24 & reteplase:TI,AB,KY & 109 \\
\hline \#25 & tenecteplase:TI,AB,KY & 142 \\
\hline \#26 & saruplase:TI,AB,KY & 33 \\
\hline \#27 & anistreplase:TI,AB,KY & 156 \\
\hline \#28 & monteplase:TI,AB,KY & 14 \\
\hline \#29 & streptokinase:TI,AB,KY & 1276 \\
\hline \#30 & staphylokinase:TI,AB,KY & 17 \\
\hline \#31 & (avelizin or awelysin):TI,AB,KY & 0 \\
\hline \#32 & (celiase or distreptase or Kabikinase or kabivitrum):TI,AB,KY & 12 \\
\hline \#33 & (Streptase or streptodecase or apsac or Abbokinase or renokinase ):TI,AB,KY & 110 \\
\hline \#34 & $\begin{array}{l}\text { (Actilyse or Activase or Eminase or Retavase or Rapilysin or desmopletase or u-pa or al- } \\
\text { fimeprase ):TI,AB,KY }\end{array}$ & 85 \\
\hline \#35 & (streptodornase): $\mathrm{TI}, \mathrm{AB}, \mathrm{KY}$ & 50 \\
\hline \#36 & (pro? urokinase or rpro?uk ):TI,AB,KY & 44 \\
\hline \#37 & (lumbrokinase or duteplase or lanoteplase or pamiteplase):TI,AB,KY & 44 \\
\hline \#38 & $\begin{array}{l}\# 13 \text { OR \#14 OR \#15 OR \#16 OR \#17 OR \#18 OR \#19 OR \#20 OR \#21 OR \#22 OR \#23 OR \#24 OR } \\
\text { \#25 OR \#26 OR \#27 OR \#28 OR \#29 OR \#30 OR \#31 OR \#32 OR \#33 OR \#34 OR \#35 OR \#36 OR } \\
\# 37\end{array}$ & 17883 \\
\hline \#39 & \#12 AND \#38 & 5255 \\
\hline \#40 & * NOT SR-PVD:CC AND 31/05/2013 TO 31/01/2016:DL & 231856 \\
\hline \#41 & \#39 AND \#40 & 1054 \\
\hline
\end{tabular}


WHAT'S NEW

\begin{tabular}{lll}
\hline Date & Event & Description \\
\hline 25 February 2016 & New search has been performed & $\begin{array}{l}\text { Search updated. No new included studies. New data from previ- } \\
\text { ously included study added. Seven new studies excluded. Two } \\
\text { new ongoing studies added. }\end{array}$ \\
\hline 25 February 2016 & $\begin{array}{l}\text { New citation required but conclusions } \\
\text { have not changed }\end{array}$ & $\begin{array}{l}\text { Search updated. No new included studies. Seven new studies } \\
\text { excluded. Two new ongoing studies added. New data from pre- } \\
\text { viously included study added. Text amended to reflect current } \\
\text { Cochrane policy. 'Summary of findings' table added. }\end{array}$ \\
\hline
\end{tabular}

\section{H I S T O R Y}

Protocol first published: Issue 4, 2000

Review first published: Issue 4, 2004

\begin{tabular}{lll}
\hline Date & Event & Description \\
\hline 6 June 2013 & $\begin{array}{l}\text { New citation required but conclusions } \\
\text { have not changed }\end{array}$ & $\begin{array}{l}\text { New search carried out. New author joined the review team. One } \\
\text { new study included, four previously excluded studies now in- } \\
\text { cluded. One new study excluded. Risk of bias assessed for all in- } \\
\text { cluded studies and text updated. No change to conclusions. }\end{array}$ \\
\hline 6 June 2013 & New search has been performed & $\begin{array}{l}\text { One new study included, four previously excluded studies now } \\
\text { included. One new study excluded. }\end{array}$ \\
\hline 11 November 2009 & Amended & Some graph labels changed and minor edits made to the text. \\
\hline 12 November 2007 & New search has been performed & $\begin{array}{l}\text { Four additional excluded studies added. Dates of searches up- } \\
\text { dated. Plain Lanugage Summary provided by the Cochrane Con- } \\
\text { sumer Network added and edited by author. Minor copy edits } \\
\text { throughout text.. Analyses graphs copy edited for uniformity in } \\
\text { presentation. Technical edits performed to clarify outcome sta- } \\
\text { tistics. Conclusions remain unchanged. }\end{array}$ \\
\hline
\end{tabular}

\section{CONTRIBUTIONS OFAUTHORS}

LW: assessed reference list, extracted data, updated review text $\mathrm{CB}$ : assessed reference list, extracted data, updated review text MPA: updated review text, resolved differences where required

\section{DECLARATIONSOF INTEREST}

LW: has declared that she received travel and accomodation fees from the European Society of Angiology for speaking at the 2012 meeting on this topic

CB: CB is a member of Cochrane Vascular's editorial base staff. Where appropriate, editorial tasks were carried out by other group members MPA: none known 


\section{SOURCES OF SUPPORT}

\section{Internal sources}

- No sources of support supplied

\section{External sources}

- Chief Scientist Office, Scottish Government Health Directorates, The Scottish Government, UK.

The Cochrane Vascular editorial base is supported by the Chief Scientist Office.

- National Institute for Health Research (NIHR), UK.

This project was supported by the NIHR, via a Cochrane Programme Grant funding (13/89/23) to Cochrane Vascular. The views and opinions expressed therein are those of the authors and do not necessarily reflect those of the Systematic Reviews Programme, NIHR, NHS or the Department of Health.

\section{DIFFERENCES BETWEEN PROTOCOLANDREVIEW}

After consideration, the review authors decided to increase the inclusion period of acute symptoms of DVT from 14 to 21 days as this is more commonly used in recent studies. Trials previously excluded due to this were reassessed and included.

In the initial published version, the quality of the trials was investigated using the methods of Jadad (Jadad 1996) and Schulz (Schultz 1995). In keeping with updated Cochrane Collaboration requirements, quality has now been assessed using the Cochrane risk of bias tool (Higgins 2011).

For the 2016 update we changed the time point definitions to differentiate late outcomes after five years as two studies (Arneson 1978; Enden 2011) now reported results within this period. Due to this Arneson 1978 data was re-categorised from intermediate to late.

\section{N DEX TERMS}

\section{Medical Subject Headings (MeSH)}

Anticoagulants [ ${ }^{\star}$ therapeutic use]; Randomized Controlled Trials as Topic; Thrombolytic Therapy [adverse effects] [ ${ }^{\star}$ methods]; Treatment Outcome; Varicose Ulcer [prevention \& control]; Venous Thrombosis [complications] [ ${ }^{*}$ drug therapy]

\section{MeSH check words}

Humans 